\title{
Sediment and basement contact coring ${ }^{1}$
}

\author{
Expedition 336 Scientists $^{2}$
}

\section{Chapter contents}

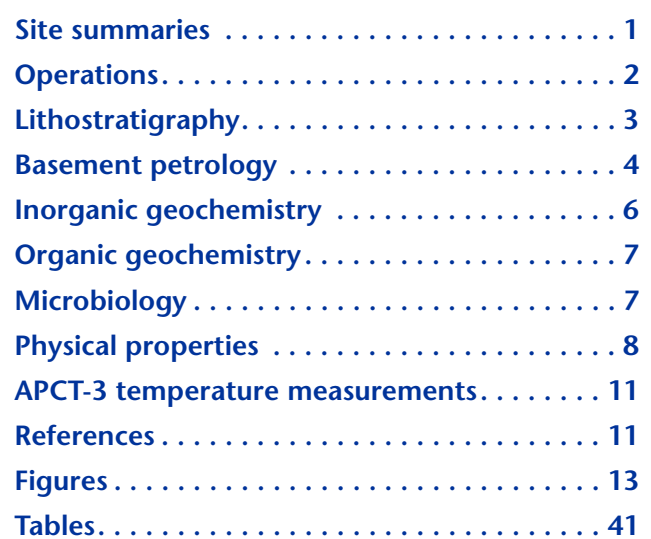

${ }^{1}$ Expedition 336 Scientists, 2012. Sediment and basement contact coring. In Edwards, K.J., Bach, W., Klaus, A., and the Expedition 336 Scientists, Proc. IODP, 336: Tokyo (Integrated Ocean Drilling Program Management International, Inc.). doi:10.2204/iodp.proc.336.106.2012

'Expedition 336 Scientists' addresses.

\section{Site summaries}

This section summarizes the results of advanced piston corer (APC) sediment coring and extended core barrel (XCB) coring of the sediment-basement transition at Integrated Ocean Drilling Program (IODP) Sites U1383 (prospectus Site NP-2), U1382 (near Deep Sea Drilling Project [DSDP] Hole 395A), and U1384 (prospectus Site NP-1).

In Hole U1383D, $44.3 \mathrm{~m}$ of sediment was cored, of which the lowermost $1 \mathrm{~m}$ was XCB cored through basalt and limestonecemented breccia $(0.76 \mathrm{~m}$ of basement was recovered). At nearby Hole U1383E, $44.2 \mathrm{~m}$ of sediment and $1 \mathrm{~m}$ of basaltic basement was cored ( $0.3 \mathrm{~m}$ of basement was recovered). The basalts are aphyric and slightly to moderately altered. They are distinct from the uppermost basaltic flow that was cored with the rotary core barrel (RCB) in Hole U1383C and hence represent a different lithologic unit.

Hole U1382B was drilled midway between Holes 395A and U1382A. A total of $90.0 \mathrm{~m}$ of sediment was APC cored, and another $8.8 \mathrm{~m}$ was cored with the $\mathrm{XCB}$, recovering a piece of basalt and countless millimeter- to centimeter-sized pebbles of completely altered plutonic and ultramafic rocks at the basement/sediment interface. These rocks are interpreted to be part of the sedimentary breccia overlying the massive basalt of lithologic Unit 1 cored in Hole U1382A.

Coring in Hole U1384A recovered $93.5 \mathrm{~m}$ of sediment overlying $0.58 \mathrm{~m}$ of basalt and limestone-cemented breccia. The basalts are aphyric and sparsely vesicular with glassy to variolitic to microcrystalline groundmass. They are between 3\% and 10\% altered and display brown alteration halos along clay veins and fractures.

The sediments at all sites consist of foraminifer nannofossil ooze with layers of foraminiferal sand. The bottom several meters of the sedimentary pile are brown and appear rich in clay. Sediments from Hole U1382B show moderately rounded rock fragments concentrated in layers or dispersed in the ooze. These fragments range from coarse sand to pebble in grain size and consist of serpentinized mantle peridotite, gabbro, troctolite, and basalt. Both XCB cores from Hole U1382B also contain coarse sediment with predominantly serpentinite clasts, including soapstone and talctremolite schist. The occurrence of these rock fragments is consistent with the polymict sedimentary breccia recovered during basement drilling in Holes 395A and U1382A. The deformed and 
metasomatized lithologies encountered in Hole U1382B corroborate the hypothesis that this material was transported to the Site U1382 area in North Pond by mass wasting events and that its source is an oceanic core complex, probably in the southern rift mountains. Layers of foraminiferal sand are abundant in all holes, and many show erosional bases and normal-graded bedding, suggesting that they represent deposits of turbidity currents.

Each of the four holes cored was intensively sampled for microbiological and interstitial water analyses. The sampling program was similar for each hole. In total, we collected 167 whole-round samples for interstitial waters and 691 whole-round samples for microbiological analysis. Sampling density was increased in the bottom sections. Pore waters in these basal sediments are dominated by diffusion of components from the basement fluids into the sedimentary pile, and they allow estimation of basement fluid compositions by extrapolation. Whole-round cores were preserved for shore-based molecular analysis to provide a detailed description of the microbial community. Ship-based enrichment cultures were established to enrich for multiple metabolic functional groups. These cultures will be analyzed on shore for both metabolic activity and community composition. Sediment sections remaining after whole-round sampling were analyzed for oxygen concentration using optodes. Hard rock samples were sectioned and allocated following previous strategies established during the hard rock drilling phase of the expedition. Multiple basalt samples were provided for RNA/DNA, geochemistry, and culture analyses.

An extensive high-resolution physical properties data set was obtained for all holes. This data set includes whole-round, split-core, and discrete measurements of magnetic susceptibility, velocity, density, porosity, natural gamma radiation, and resistivity.

\section{Operations}

The final operations of Expedition 336 were focused on APC/XCB coring of the sediment above basement and the sediment/basement contact in four holes. A summary of operations completed in Holes U1383D, $\mathrm{U} 1383 \mathrm{E}, \mathrm{U} 1382 \mathrm{~B}$, and U1384A is presented in Table T1. Information about the holes and cores recovered is presented in Table T2.

\section{Hole U1383D}

The APC/XCB bottom-hole assembly (BHA) was made up with a new APC/XCB bit and lowered to $4 \mathrm{~m}$ above seafloor. The vessel was positioned halfway between Holes U1383B and U1383C, offset $5 \mathrm{~m}$ to the northwest, and Hole U1383D was spudded at 1426 h on 7 November 2011 (all times are local ship time, Universal Time Coordinated [UTC] -3 h). Six APC cores were taken from 0 to 43.3 meters below seafloor (mbsf) (Cores 336-U1383D-1H through 6H) and recovered $47.89 \mathrm{~m}$ of sediment. Core $6 \mathrm{H}$ only penetrated $0.2 \mathrm{~m}$ before hitting basement, so the majority of the recovery was sucked in when pulling the barrel out of the formation. After hitting basement with the last APC core, we penetrated $1 \mathrm{~m}$ with Core 336-U1383D-7X and recovered $0.76 \mathrm{~m}$. Hole U1383D ended at $2350 \mathrm{~h}$ on 7 November when the bit cleared the seafloor.

\section{Hole U1383E}

The vessel was offset $10 \mathrm{~m}$ to the southeast, and Hole U1383E was spudded at $0038 \mathrm{~h}$ on 8 November. APC Cores 336-U1383E-1H through $6 \mathrm{H}$ extended to $43.2 \mathrm{mbsf}$ and recovered $50.38 \mathrm{~m}$ of sediment. Core $6 \mathrm{H}$ only penetrated $2.3 \mathrm{~m}$ before encountering basement, so the remaining $6.22 \mathrm{~m}$ of sediment recovered was likely sucked in when the barrel was pulled out of the formation. After the last piston core hit basement, the XCB core barrel was dropped, and the sediment/basement interface was cored for $\sim 1 \mathrm{~h}$ to 44.2 mbsf. Core 336-U1383E-7X recovered $0.3 \mathrm{~m}$. Hole U1383E ended at $1000 \mathrm{~h}$ on 8 November when the bit cleared the seafloor.

\section{Hole U1382B}

After pulling out of Hole U1383E and raising the bit well above seafloor (4300 meters below rig floor [mbrf]), we moved in dynamic positioning (DP) mode to Site U1382. After the $3.28 \mathrm{nmi}$ transit was completed at $1445 \mathrm{~h}$, the bit was lowered to just above the seafloor and the top drive was picked up and spaced out for spudding. Hole U1382B was spudded at $1700 \mathrm{~h}$ on 8 November. APC Cores 336U1382B-1H through $10 \mathrm{H}$ extended to $90.0 \mathrm{mbsf}$ and recovered $83.70 \mathrm{~m}$ of sediment. Core $10 \mathrm{H}$, the last APC core, encountered basement after penetrating $\sim 8.5 \mathrm{~m}$, so the lowermost portion of sediment recovered in this core is likely flow-in. Temperature measurements with the advanced piston corer temperature tool (APCT-3) were attempted on Cores $3 \mathrm{H}$ through $5 \mathrm{H}$. The measurements were not good as a result of tool movement, and the measurements were discontinued because they were thought to be disturbing the sediment cores. Subsequent splitting of the cores seemed to indicate that the disturbed cores could have been caused by the lithology of the cores-coarse sediments as large as pebble size were found inside the cores. After basement was hit with the last piston core, the XCB core barrel was 
dropped, and the sediment/basement interface was cored. After a few minutes of XCB coring, the formation changed, and the XCB quickly advanced to the remainder of the kelly length $(4.7 \mathrm{~m})$. After Core 336-U1382B-11X was pulled, another core barrel was dropped, and XCB coring continued until hard formation was encountered around 98.8 mbsf. After $30 \mathrm{~min}$ of coring with no advance, Core 336U1382B-12X was pulled. The XCB cutting shoe had lost all of its carbide teeth, and only $18 \mathrm{~cm}$ of core was recovered. Cores 336-U1382B-11X and $12 \mathrm{X}$ recovered a total of $0.58 \mathrm{~m}$ over an $8.8 \mathrm{~m}$ interval. Hole U1382B ended at 1315 h on 9 November when the bit cleared the seafloor.

\section{Hole U1384A}

After raising the bit above the seafloor (4400 mbrf), we moved in DP mode to Site U1384. The $3.38 \mathrm{nmi}$ transit was completed at $1815 \mathrm{~h}$. We lowered the bit to just above the seafloor, picked up the top drive, and spaced out for spudding. Hole U1384A was spudded at 2130 h on 9 November. APC Cores 336U1384A-1H through $11 \mathrm{H}$ extended to $94.7 \mathrm{mbsf}$ and recovered $93.51 \mathrm{~m}$ of sediment. Core $11 \mathrm{H}$ was only a partial stroke, likely because basement was encountered. XCB Core 336-U1384A-12X advanced $1.5 \mathrm{~m}$ in $\sim 40 \mathrm{~min}$, where penetration stopped. When Core 12X was retrieved, $0.58 \mathrm{~m}$ of core had been recovered and the XCB cutting shoe had lost all of its carbide teeth. Hole U1384A ended at $0042 \mathrm{~h}$ on 11 November.

After the drill string was back on board, the BHA was disassembled and the drill floor was secured for transit. Transit to Ponta Delgada began at $0042 \mathrm{~h}$ on 11 November for a planned arrival time in Ponta Delgada of $0730 \mathrm{~h}$ on 17 November.

\section{Lithostratigraphy}

APC coring was used to sample the sediment overlying basement in Holes U1382B, U1383D, U1383E, and U1384A (Fig. F1). Thirty-three APC cores were recovered. When basement was encountered, one or two XCB cores were cut across the sediment/basement interface. Sediment coring was conducted at the very end of the expedition, and only minimal core description was conducted.

The lithology of all four holes is dominated by foraminifer nannofossil ooze with variable proportions of foraminifers and nannofossils. Well-sorted foraminifers and occasionally fining-upward sand layers (turbidites) are present in all holes. An interval in Hole U1382B contains muddy gravels containing sand- to pebble-sized serpentinite, gabbro, and basalt clasts supported by a nannofossil ooze matrix.

\section{Hole U1382B}

In Hole U1382B, we cored $98.8 \mathrm{~m}$ and recovered $84.28 \mathrm{~m}$ (85\% recovery). Ten APC cores and two XCB cores were obtained. Sediments are mostly light brown to reddish-yellow foraminifer nannofossil ooze. Some layers of foraminifer nannofossil ooze may contain sandy to pebbly angular black clasts. Three of these pebbly clasts are serpentinite and one is gabbro (Sections 336-U1382B-6H-8 and 7H-1). Some layers of muddy gravel have sandy to pebbly clasts. These muddy gravels are often supported by a matrix of nannofossil-rich ooze and are clearly the result of downslope transport. Cores exhibit weak to high coring disturbance (biscuiting, soupiness, and cracks). Two fining-upward sequences (Sections 336U1382B-6H-5 and 10H-5) were identified. A typical fining-upward sequence occurs from the bottom to the top of an erosional base (e.g., a sandy facies settling on a muddy facies) and above a decrease in grain size in the successive layers made of the foraminifer nannofossil ooze. Although this sequence lacks of some typical parts of the Bouma sequence (Bouma, 1962), the fining-upward sequences overlying an erosional base appear to be turbidites.

At the base of the section, near the oceanic crust, foraminifer nannofossil ooze layers have a strong brown color (7.5YR 4/6 to 3/4)-perhaps the result of an enrichment in Fe and $\mathrm{Mg}$ coming from the basement. The basal section also contains fragments of basalt, gabbro, and serpentinized peridotite.

\section{Hole U1384A}

In Hole U1384A, we cored $96.2 \mathrm{~m}$ and recovered $94.1 \mathrm{~m}$ (98\% recovery). Cores included 11 APC cores and 1 XCB core. Light brown to reddish foraminifer nannofossil ooze with variable proportions of foraminifers and nannofossils represents the dominant lithology recovered. Cores record slight soupy coring disturbance. As in Hole U1382B, the sediments near basement (Cores 336-U1384A-10H and $11 \mathrm{H}$ ) are foraminifer nannofossil ooze with a strong brown color (7.5YR $4 / 6$ to $3 / 4$ ). The brownish tints might result from staining of nannofossils by iron oxides (Shipboard Scientific Party, 1979). The layers in turn differ in color because of varying ratios of stained nannofossils to foraminifers; the lightest layers are the foraminifer sands, which are typically $10-20 \mathrm{~cm}$ thick in this hole.

Sedimentary structures observed include parallel laminations, a slump, a lot of fining-upward sequences, and bioturbation. The slump observed contains clasts of darker, more consolidated nannofossil-rich ooze. Overall, 20 fining-upward sequences, interpreted as turbidites, were observed throughout the hole. In 
contrast to Hole U1382A, no rock clasts are present, and the sediments are not as affected by coring disturbance.

\section{Site U1383}

Two holes at Site U1383 were cored $\sim 10 \mathrm{~m}$ apart: Holes U1383D and U1383E.

\section{Hole U1383D}

In Hole U1383D, we cored $44.3 \mathrm{~m}$ and recovered $48.65 \mathrm{~m}$ (110\% recovery). Six APC cores and one $\mathrm{XCB}$ core were obtained. Light brown foraminifer nannofossil ooze with variable proportions of foraminifers and nannofossils represent the main lithology. Fining sequences and layers with sandy to pebbly black angular clasts were also observed. Core disturbance is minimal except in the last core (336U1383D-6H), which is highly disturbed (soupy)likely from flow-in resulting from a partial APC stroke. Because of this disturbance, it is not clear if the color change just above basement observed at other sites is present here. However, Core 336U1383D-5H does exhibit some strong brown color.

\section{Hole U1383E}

In Hole U1383E, we cored $44.2 \mathrm{~m}$ and recovered $50.28 \mathrm{~m}$ (114\% recovery). Six APC cores and one $\mathrm{XCB}$ core were obtained. Sediments recovered from Hole U1383E are represented by light brown to reddish-yellow foraminifer nannofossil ooze with variable proportions of foraminifers and nannofossils. Some layers containing well- to poorly sorted sandy to pebbly black angular clasts are present. Four finingupward sequences were observed and interpreted as turbidites. No color changes in the basal sediments were observed, and core disturbance is moderate (cracks and soupiness).

\section{Synthesis}

The sediment sections observed during Expedition 336 are similar to those obtained during the previous drilling program (Shipboard Scientific Party, 1979, 1998; Timofeev et al., 1979). Turbidite sequences are present in all of the sections, but, unfortunately, no correlations can be made at this stage.

The color change in the basal section may be the result of Fe and Mn enrichment, but geochemical analysis must be done to confirm this hypothesis. Previous coring (Shipboard Scientific Party, 1979, 1998) identified a single lithologic unit (Unit I) composed of nannofossil ooze with varying amounts of foraminifers, clay, radiolarians and sand, and nannofossil clay. This unit was divided into Subunit IA, composed of nannofossil ooze containing varying amounts of clay, foraminifers, and radiolarians, and Subunit IB, composed of red clay with only $\sim 20 \%$ carbonate. Foraminifer nannofossil ooze recovered from IODP Expedition 336 sites can be correlated with Subunit IA. Although we did not identify Subunit IB in the four holes cored, this subunit could correspond to the one or two cores above the sediment/ basement contact that have a dark brown color and are very homogeneous.

\section{Basement petrology}

\section{Hole U1382B}

Basement was encountered at 90 mbsf in Hole $\mathrm{U} 1382 \mathrm{~B}$, and $58 \mathrm{~cm}$ from $\sim 8.8 \mathrm{~m}$ of cored basement was recovered (6.6\% recovery). Only one basalt piece was recovered in Section 336-U1382B-11X-CC. The rest of the basement rocks in Core 336-U1382B-12X are pebbles of completely altered plutonic and mantle rocks composed of talc-tremolite schist and serpentinite (Fig. F2). The ultramafic rocks occurring at the basement/sediment interface are interpreted as being part of sedimentary breccia overlying the massive basalt of lithologic Unit 1 in Hole U1382A, described in the "Site U1382" chapter (Expedition 336 Scientists, 2012b).

Unexpectedly, serpentinized ultramafic rocks and one piece of troctolite were recovered from within the sediment sequence between 49.8 and $53.1 \mathrm{mbsf}$ in Sections 336-U1382A-6H-7 through 7H-1 (Fig. F3). The occurrence of plutonic and ultramafic rocks of various sizes (from sand to pebble size, with clasts up to $8 \mathrm{~cm}$ in diameter) within a soft-sediment matrix (clayey foraminifer-rich ooze) suggests that this sequence represents a gravity flow that has traveled down the slopes of nearby rift mountains with outcrops of highly deformed plutonic and mantle rocks (i.e., oceanic core complex). This interpretation is consistent with the occurrence of similar plutonic and mantle rocks at $\sim 60$ meters subbasement (msb) in DSDP Holes 395 and 395A (Shipboard Scientific Party, 1979) and Hole U1382A (see "Petrology, hard rock and sediment geochemistry, and structural geology" in the "Site U1382" chapter [Expedition 336 Scientists, 2012b]).

\section{Mafic and ultramafic rocks from APC core}

The troctolite piece recovered in Section 336U1382B-7H-1 has been intensively serpentinized (up to $80 \%)$ and consists of plagioclase (20\%) and olivine $(80 \%)$ as primary minerals. The troctolite has a granular texture of euhedral olivine and subhedral plagioclase and lacks obvious foliation and lineation texture (Fig. F3C). The serpentinite pieces retrieved 
from Sections 336-U1382B-6H-7 and 6H-8 are black, dark green, and greenish white on the cut surface (Fig. F3A, F3B). In some parts, the serpentinites are dominated by a tangerine color, indicating a higher degree of weathering (up to 100\%). Serpentinites are composed of serpentine that has a typical mesh texture with minor Fe hydroxide-rich clays. Coarse- to medium-sized grains $(0.5-1 \mathrm{~cm})$ of bastite (serpentine pseudomorph of orthopyroxene) in the olivine matrix give the rock a porphyroclastic texture. Black spinel grains occur in several serpentinites, but some spinel may have been replaced by magnetite. Most of the serpentinites lack macroscopic deformation fabric, although several pieces have developed foliation defined by elongated and rounded pyroxene grains. These two types of serpentinites were grouped as "undeformed" and "deformed," respectively.

\section{Ultramafic rocks from XCB core}

Ultramafic rocks recovered in Core 336-U1382B-12X are small pebbles with variable angular to subrounded shapes (Fig. F2). There are also several basalt and chalk fragments in Section 336-U1382B-12X-1 (Piece 4) (Fig. F2D). Three talc-amphibole rocks (Sections 336-U1382B-12X-1 [Piece 1] and 12X-1 [Piece $3]$ ) were retrieved, and these range in color from green to greenish white. The constituent minerals are talc and amphibole (most probably tremolite). Two of the talc-amphibole rocks exhibit strong schistosity, which led to their classification as "talc-amphibole schist," whereas rocks in Section 336-U1382B-12X-1 (Piece 1) lack schistosity. Talc-amphibole rocks may represent products of metasomatism in detachment faults (e.g., Boschi et al., 2006).

Serpentinites retrieved in Core 336-U1382B-12X are black, dark green, or greenish white, whereas several serpentinites are mainly tangerine. The serpentinite is composed of serpentine (with mesh texture) and talc with minor Fe oxide-rich clay. Coarse- to mediumsized grains $(\sim 0.2$ to $\sim 1.8 \mathrm{~cm})$ are probably bastite or talc occurring as pseudomorphs of pyroxene, preserving the original texture.

\section{Structural geology and deformation}

The serpentinites obtained from both APC and XCB cores contain mesh textures and bastite, indicating static replacement and serpentinization of essentially undeformed peridotites (e.g., Mével, 2003). On the basis of macroscopic observation, most serpentinites lack deformation such as schistosity, indicating the structures are probably relics from peridotites that predate the serpentinization and Si-metasomatism (e.g., Bach et al., 2004; Boschi et al., 2006; Mével, 2003; Hirauchi and Yamaguchi, 2007; Hirauchi et al., 2010). Hence, most serpentinites from Site U1382 could derive from weakly deformed lithospheric mantle. Other serpentinites and the talc-amphibole schists, with their well-developed porphyroclastic texture, could be related to localized ductile shear zones in the lithospheric mantle (e.g., Michibayashi et al., 2009; Harigane et al., 2011). Thus, the occurrence of deformed ultramafic rocks in Hole U1382B could be related to the formation of a nearby oceanic core complex.

\section{Holes U1383D and U1383E}

Basement was encountered at 43.3 mbsf in Hole U1383D and at 43.21 mbsf in Hole U1383E. Less than $110 \mathrm{~cm}$ of basement was recovered from both sites (76 cm in Hole U1383D and $30 \mathrm{~cm}$ in Hole U1383E). All basement rocks were assigned to the same basement lithologic unit, although several sedimentary breccia intervals are also present. The basalts, mainly aphyric and sparsely vesicular, are slightly to moderately altered and grayish brown in color, and they display brown alteration halos along veins and exposed fractures. Interestingly, the basement rocks are different from those encountered at $69.5 \mathrm{mbsf}$ in Unit 1 of Hole U1383C (sparsely plagioclase-olivinephyric basalts), which suggests the existence of at least one volcanic unit between 43.2 and $69.5 \mathrm{mbsf}$. Note also that the interflow sediments recovered in Hole U1383D are less consolidated than those recovered in Hole U1383C, indicating that the occurrence of limestone deeper in the section may result from baking and carbonate recrystallization during emplacement of successive basalt flows.

\section{Hole U1383D}

The volcanic section recovered in Core 336-U1383D$7 \mathrm{X}$ is composed of aphyric to sparsely porphyritic glassy to microcrystalline basalts (e.g., Fig. F4). Half of the recovered pieces have glassy chilled margins. The basalts are avesicular to sparsely vesicular, and small amounts (up to 1\%) of elongated tabular plagioclase phenocrysts were observed in sparsely porphyritic specimens. Core 336-U1383D-7X also features common sedimentary breccia, either as individual pieces or still in contact with basaltic rocks (Fig. F5). The sedimentary breccias are composed of $60 \%-40 \%$ of poorly sorted palagonitized glass shards in a matrix of light brown clayey chalk. Recrystallized carbonate cement occasionally occurs around glass clasts and at the contact between the breccias and basalt (Fig. F5B).

Groundmass alteration is patchy to pervasive, with an overall alteration intensity ranging from fresh ( $<1 \%$ alteration) to moderate (up to $30 \%$ alteration). Chilled margins display variably palagonitized glass with common reddish-brown alteration. Vesicle 
abundance ranges from $1 \%$ to $3 \%$, with $<30 \%$ filling with mainly carbonate (possibly associated with zeolite) and minor smectite and Fe oxyhydroxide. Average vein density is $\sim 25$ veins $/ \mathrm{m}$, which compares well with vein density in Unit 1 of Hole U1383C (see the "Site U1383" chapter [Expedition 336 Scientists, $2012 \mathrm{c}]$ ). Vein width is generally $<0.4 \mathrm{~mm}$, and veins are composed of mixed smectite and Fe oxyhydroxide ( \pm iddingsite). A single vein (as wide as $3 \mathrm{~mm}$ ) was found in Section 336-U1383D-7X-CC (Piece 8) and is composed of mixed carbonate and clayey sediment infill. Dark brown to grayish-brown halos are well developed along veins (Fig. F4).

\section{Hole U1383E}

Only seven pieces were recovered in Core 336U1383E-7X, comprising mainly aphyric avesicular to sparsely vesicular microcrystalline basalts (Sections 336-U1383E-7X-1 [Piece 2] through 7X-1 [Piece 7]) and including two samples with chilled margins. As observed in Hole U1383D, small amounts of sediment and sedimentary breccia were recovered in contact with exposed fractures of basalt. Section 336-U1383E$7 \mathrm{X}-1$ (Piece 1) is a fragment of highly plagioclaseclinopyroxene-phyric holocrystalline dolerite, which differs markedly from other basalts recovered at Site U1383. The basalts are sparsely vesicular to nonvesicular $(<2 \%$ vesicles), and vesicles generally lack secondary mineral filling, except in Section 336U1383E-7X-1 (Piece 1), where vesicles are filled with dark green smectitic clay.

Alteration of the groundmass is patchy and generally moderate $(<6 \%)$, except in Section 336-U1383E-7X-1 (Piece 2$)$, which is pervasively altered $(<40 \%)$. The dolerite, Section 336-U1383E-7X-1 (Piece 1), is also moderately to highly altered $(<50 \%)$.

\section{Hole U1384A}

Basement was encountered at $94.71 \mathrm{mbsf}$ in Hole $\mathrm{U} 1384 \mathrm{~A}$, and $58 \mathrm{~cm}$ of basement was recovered. All volcanic rocks, interflow sediments, and sedimentary breccias were assigned to the same basement lithologic unit. The basalts are aphyric and sparsely vesicular with a glassy to microcrystalline groundmass. This unit is composed of pillow lava with common variolitic texture that lacks glassy chilled margins. The basalts are slightly to moderately altered (3\%$10 \%$ ) and grayish brown in color, and display brown alteration halos along veins and exposed fractures. Variolitic basalts display blotchy alteration textures, similar to the pillow lava units encountered in Holes U1382A and U1383C.

Vesicle abundance ranges from $<0.5 \%$ to $3 \%$, with very limited filling $(<10 \%)$. Only Section 336-
U1384A-12X-1 (Piece 13) has $>80 \%$ vesicle filling, composed of dark green smectite and Fe oxyhydroxide. Only two veinlets $(0.1 \mathrm{~mm}$ width $)$ were logged in this sequence; they are composed of typical smectite-iddingsite assemblages found deeper in the basement in Holes U1382A and U1383C (see the "Site U1382" and "Site U1383" chapters [Expedition 336 Scientists, 2012b, 2012c]). Dark brown to brown halos are well developed along veins and the exposed surface of the rocks (Fig. F6).

Section 336-U1384A-12X-1 features common sedimentary breccia, either as individual pieces of interflow sediments or still in contact with basaltic rocks (Fig. F6). The sedimentary breccia (Sections 336U1384A-12X-1 [Piece 1], 12X-1 [Piece 2], 12X-1 [Piece 3], 12X-1 [Piece 4], and 12X-2 [Piece 11]) is composed of poorly sorted altered basalt and clayey sediment clasts (defined as slumps) within a matrix composed of light brown sediment (clayey chalk). Note also that the interflow sediment recovered in Hole U1384A is less consolidated than that recovered in Hole U1383C and generally similar to that recovered at the sediment/basement interface in Hole U1383D.

\section{Inorganic geochemistry}

Sediment pore water samples were collected from all four Holes, as well as from two sediment layers recovered during RCB coring in Hole U1382A (see the "Site U1382" chapter [Expedition 336 Scientists, 2012b]), using two different methods: extraction with Rhizon samplers and extraction by squeezing (see the "Methods" chapter [Expedition 336 Scientists, 2012a]). Eighty-nine pore water samples collected using Rhizon samplers were analyzed for dissolved nitrate, phosphate, ammonium, and chlorinity (Fig. F7; Tables T3, T4). Nitrate concentrations are greater than the bottom water value reported by Ziebis et al. (2012). In general, concentrations increase in the shallowest $5 \mathrm{~m}$ of the sediment column and remain uniform with depth. Within 5-10 m of the estimated sediment/basement interface, concentrations generally decrease toward the seawater value. This trend is not observed in Hole U1382B, possibly because the hydrologic basement is at 98.8 meters below sea level (mbsl), $8.8 \mathrm{~m}$ deeper than the depth of the initial encounter with a hard layer. After initial contact with this hard layer, drilling progress was fast, similar to that of sediment, to 98.8 mbsf, when drilling progress slowed.

Phosphate values increase above the bottom seawater value in the shallowest few meters of the sediment and then generally decrease downcore. Values decrease to about $1 \mu \mathrm{M}$ at the sediment/basement 
interface. Ammonium values should be viewed with caution considering high dilutions necessary to analyze the samples, which results in high limits of detection. Samples from Holes U1383D and U1383E had a detection limit of $6 \mu \mathrm{M}$ for ammonium because of the dilution used. Given the nature of potential contamination for ammonium, recorded values are likely high but suggest higher values near the sediment/basement interface. The second batch (Holes U1382B and 1384A), with a much lower sample dilution before analysis, resulted in much lower concentrations and a detection limit of $1.5 \mu \mathrm{M}$.

Chlorinity was analyzed for each of these Rhizon samples but is not reported here. This is because values were sporadic with less discernible trends relative to those determined from measurements based on pore water extracted by squeezing sediment. The sporadic nature of these results probably stems from the samples beings stored frozen, introducing an artifact during the thawing phase.

One hundred and twenty-six samples collected from squeezing sediment were analyzed for chlorinity, $\mathrm{pH}$, alkalinity, and the major, minor, and some trace elements in pore water. In general, our results are consistent with concentrations and trends observed from Ocean Drilling Program Hole 1074A (Shipboard Scientific Party, 1998). For example, chlorinities (and calculated $\mathrm{Na}$ ) values increase to a maximum and then decrease to bottom seawater values at two sites but remain high at Site 1383, consistent with the diffusion of the glacial-interglacial signal through the sediment column (McDuff, 1985). Similarly, Sr concentrations increase to a maximum; however, values decrease to bottom seawater values in only one of the four boreholes.

Trends for the other major ions in seawater $(\mathrm{Mg}, \mathrm{Ca}$, $\mathrm{K}, \mathrm{S}$ [as sulfate], and alkalinity) are consistent with shallow sediment and cool basement temperature. Aside from the alkalinity, concentrations are little changed from bottom seawater values with potential basement fluid compositions that are several percent different than bottom seawater values. Measured alkalinity, however, increases from the bottom seawater value to a maximum then decreases with depth to values below that in bottom seawater. Shipboard sulfate data are not reported because of analytical issues, and the resulting scatter in the data greatly exceeded that of the shore-based data.

The minor elements Li and B are generally uniform with depth. The other minor elements (Mn, Fe, and $\mathrm{Si}$ ) are generally reactive. Hole U1382B has a clearly defined Mn maximum in the middle of the sediment column. Mn concentrations are about $1 \mu \mathrm{M}$ in all of the other samples. The Fe values are generally below detection with several "spikes" that are generally
$<0.5 \mu \mathrm{M}$; only one datum exceeds $1 \mu \mathrm{M}$ Fe. Dissolved silica concentrations are generally uniform with depth but trend toward higher values near the sediment/basement interface.

Concentrations of the trace elements $\mathrm{V}$ and $\mathrm{Rb}$ do not vary downcore from seawater values; however, those of Mo, Cs, Ba, and $\mathrm{U}$ do show consistent trends with depth that deviate from the seawater value in at least several of the holes. Concentrations for some of these trace metals are different from seawater values at the sediment/basement interface.

\section{Organic geochemistry}

Determination of the concentrations of organic carbon compounds in the subsurface is important to understand the extent of biological processes within the biome. Such measurements address questions central to the goals of this expedition. Organic compounds provide both an electron donor source for heterotrophic organisms and an indication of potential metabolic activity. The main focus of study for organic geochemistry was within sediment core samples acquired from Holes U1382B, U1383D, U1383E, and U1384A. Shipboard analysis was limited to volatile hydrocarbons, with total organic carbon concentrations and acetate concentrations measured postexpedition.

\section{Volatile hydrocarbons}

\section{Sample collection and processing}

Sediment samples for volatile hydrocarbon analysis were collected (up to three samples per core). A volume of $2 \mathrm{~cm}^{3}$ of sediment was collected from the center of the core using a cut-end syringe and transferred to a $20 \mathrm{~mL}$ glass serum vial with a crimp cap for volatile hydrocarbon concentration analysis on board, in accordance with standard shipboard protocol (i.e., heating at $60^{\circ} \mathrm{C}$ for $30 \mathrm{~min}$; see "Organic geochemistry" in the "Methods" chapter [Expedition 336 Scientists, 2012a]). Samples were then analyzed on a gas chromatograph to determine concentrations of $\mathrm{C}_{1}-\mathrm{C}_{3}$ compounds.

Volatile hydrocarbon concentrations were determined in a total of 25 (Hole U1382B), 12 (Hole U1383D), 15 (Hole U1383E), and 28 (Hole U1384A) headspace samples. All measured concentrations are considered to be at the detection limit of the analysis.

\section{Microbiology}

Sediments were cored with the APC and the sediment/ basement interface was cored with the XCB at three sites (U1383, U1382, and U1384). In Hole U1383D, 
$44.3 \mathrm{~m}$ of sediment was cored. Of this cored interval, the lowermost $1 \mathrm{~m}$ was XCB-cored basalt and limestone-cemented breccia $(0.76 \mathrm{~m}$ of basement was recovered). In Hole U1383E, 44.2 m of sediment and $1 \mathrm{~m}$ of basaltic basement were cored, of which $0.3 \mathrm{~m}$ was recovered. Hole U1382B was drilled midway between Holes 395A and U1382A; here, $90.0 \mathrm{~m}$ of sediment was APC cored and $8.8 \mathrm{~m}$ was advanced with the $\mathrm{XCB}$, recovering a sedimentary breccia from between 90 and 91 mbsf and basaltic basement from the bottom of the hole. In Hole U1384A, $94.7 \mathrm{~m}$ of sediment is underlain by basalt and limestonecemented breccia, of which $1 \mathrm{~m}$ was drilled and $0.6 \mathrm{~m}$ was recovered.

As described in "Lithostratigraphy," the sediment was nannofossil ooze with layers of foraminiferal sand. The lowermost several meters of the sedimentary pile are composed of brown clay. Sediments from Hole U1382B showed moderately rounded rock fragments concentrated in layers or dispersed in the ooze. These fragments ranged from coarse sand to pebble in grain size and consisted of serpentinized mantle peridotite, gabbro, troctolite, and basalt. Both XCB cores from Hole U1382B also contained coarse sediment with predominantly serpentinite clasts, including soapstone and talc-tremolite schist. The occurrence of these rock fragments was consistent with the polymict sedimentary breccia recovered during basement drilling at Sites 395 and U1382. The deformed and metasomatized lithologies encountered in Hole U1382B corroborated the hypothesis that this material was transported to the Site U1382 area in North Pond by mass wasting events and that its source was oceanic core complex, probably in the southern rift mountains.

Each of the four holes cored were intensively sampled for microbiology and interstitial water analyses, as described in detail in "Microbiology" in the "Methods" chapter (Expedition 336 Scientists, 2012a). The sampling program was similar for each of the holes. In total, 167 whole-round samples for interstitial waters and 691 whole-round samples for microbiologic analyses were collected. Sampling resolution was increased in the bottom section. As described in "Microbiology" in the "Methods" chapter (Expedition 336 Scientists, 2012a), whole-round cores were preserved for shore-based molecular analysis to provide a detailed description of the microbial community. Shipboard enrichment cultures were established to enrich for different metabolic functional groups. These cultures will be analyzed on shore for both metabolic activity and community composition. Sediment samples were also analyzed for oxygen using optodes as described in "Inorganic geochemistry" in the "Methods" chapter (Expedition 336 Scientists, 2012a). Hard rock samples were sectioned and allocated following previous strategies established during the hard rock drilling phase of the expedition. Multiple basalt samples were provided for RNA/DNA, geochemistry, and culture analyses. All requests were filled to the best ability of the group given the time and materials available.

To examine the potential for contamination in the sediment whole-round core used for microbiological analysis, the density of fluorescent microspheres in the interior and exterior of sediment cores was examined (see "Microbiology" in the "Methods" chapter [Expedition 336 Scientists, 2012a] for details). These analyses were conducted in a shorebased laboratory after the end of the expedition, using an Axiovert epifluorescence microscope with $40 \times$ objective magnification $(305 \mu \mathrm{m} \times 305 \mu \mathrm{m}$ field of view) with random selection of 20-40 fields of view. Phosphate-buffered saline (PBS)-suspended sediment sample $(20 \mu \mathrm{L})$ (see "Microbiology" in the "Methods" chapter [Expedition 336 Scientists, 2012a]) was filtered on $0.2 \mu \mathrm{m}$ mesh polycarbonate $25 \mathrm{~mm}$ diameter filters for these analyses. The results of these analyses are presented in Table T5. Not surprisingly, several of the cored sediment sections from all sediment holes had abundant microsphere contamination in the interior and exterior of the cores, as can be expected due to the sandy and disturbed nature of some of the sediment intervals. Many sections had microsphere-free interiors even when the exterior portion of the core was contaminated.

\section{Physical properties}

The sediment and hard rock from Holes U1382B, U1383D, U1383E, and U1384A were characterized for physical properties as described in the "Methods" chapter (Expedition 336 Scientists, 2012a). All of the sediment cores recovered were processed with the Whole-Round Multisensor Logger (WRMSL) for measurements of gamma ray attenuation (GRA) density, magnetic susceptibility (MS), and $P$-wave velocity at $1 \mathrm{~cm}$ resolution. $P$-wave velocity was not measured on the WRMSL for the basement contact cores because the samples were small, unsaturated pieces that did not fill the core liner fully. The $P$-wave sensor on the WRMSL cannot make good contact with such samples. All sediment cores from Holes U1382B, U1383D, and U1384A were analyzed for natural gamma radiation (NGR) total counts and potassium weight percentage on the Natural Gamma Radiation Logger (NGRL); only the uppermost five cores from Hole U1383E were processed for NGR because of time constraints. Core sections shorter than $50 \mathrm{~cm}$ were not processed for NGR. Core catcher 
samples were not analyzed, but they were scanned on the Section Half Imaging Logger (SHIL).

Thermal conductivity measurements were attempted on most core sections from Hole U1383D. However, high water content made it impossible for the probe to stabilize; hence, no measurements were successful. Therefore, we did not attempt sediment measurements in any of the other holes.

$P$-wave velocity discrete measurements were taken for all three axes in Hole U1383D samples, but because of time constraints only the $x$-axis was measured for samples from other holes. A total of 172 discrete samples were taken at a frequency of 1 per core section for moisture and density (MAD) measurements. Electrical conductivity measurements were taken every $10 \mathrm{~cm}$ with the exception of cores from Hole U1383E (because of time constraints). These measurements allowed calculation of formation factor. Areas of the core with disturbed sediment, gravel, or sandy textures were avoided because the electrodes could be damaged and the measurements would not give realistic values.

Archive core halves were scanned and analyzed for color reflectance and point magnetic susceptibility (MSP) on the Section Half Multisensor Logger (SHMSL). When sediment was too disturbed and watery and could damage the sensors, the section halves were not analyzed for color reflectance and MSP. Core catcher samples were imaged but not analyzed during the core flow.

\section{Gamma ray attenuation bulk density}

The WRMSL was used to measure MS and GRA bulk density on whole-round cores. GRA measurements are sensitive to underfilled liners. The raw data from this instrument were filtered to remove underestimated data, as described in the "Methods" chapter (Expedition 336 Scientists, 2012a). Sediment cores were considered to have a diameter of $\sim 66 \mathrm{~mm}$, and $\mathrm{XCB}$ cores were considered to have a diameter of $\sim 58 \mathrm{~mm}$ (e.g., Core 336-U1384A-12X). Hard rock cores generally have a smaller diameter $(\sim 58 \mathrm{~mm})$ than the internal diameter of the core liner $(66 \mathrm{~mm})$. This can be corrected by multiplying the system output by ${ }^{66} / 58=1.138$ (Jarrard and Kerneklian, 2007). MAD and GRA density measurements have similar values for all of the sections analyzed (Figs. F8, F9, F10, F11). GRA bulk density values agree for neighboring Holes U1383D (Fig. F8) and U1383E (Fig. F9). Layers of disturbance corresponding in some cases to sandy layers rich in foraminifers are clear and manifest as smears in the GRA bulk density. These areas were not sampled for MAD measurements because the samples did not fulfill the quality requirements due to the disturbance. A summary of GRA and MAD values including the minimum, maximum, mean, and standard deviation for each sediment site is given in Table T6. Sediments at all sites have similar ranges for GRA bulk density and MAD density measurements. Site U1383 has a lower maximum bulk density than Holes U1382B and U1384A.

\section{Magnetic susceptibility}

Magnetic susceptibility measurements of wholeround and archive-half cores are summarized in Figures F12, F13, F14, and F15. The raw data obtained from the WRMSL were filtered using the same criteria as those for GRA data because both sensors are installed on the same logger and have a similar range of detection. Magnetic susceptibility data were also corrected for the diameter of the core $(58 \mathrm{~mm}$ for hard rock [Core 336-U1384A-12X] and $66 \mathrm{~mm}$ for sediment) based on the equation given by the manufacturer (see the MS2 Magnetic Susceptibility System operation manual [www.bartington.com/ operation-manuals.html]). The correction factor applied was 1.012 for igneous sections and 0.687 for sediment sections. However, this measurement assumes that the core liner is filled, and it does not take into account the disturbance and water content of the core.

The MSP sensor is installed on the SHMSL with the color reflectance spectroscopy sensor and was filtered with the same criteria used for color reflectance, as explained in the "Methods" chapter (Expedition 336 Scientists, 2012a). No correction is needed for this measurement. Both whole-round MS and half-core MSP measurements show similar peaks. For all sites, the major peaks are attributed to the presence of rocks, rubble, or sand-sized volcanic clasts.

In Hole U1383D (Fig. F12), the two major susceptibility peaks correspond to layers of sand-sized volcanic clasts at $\sim 5$ mbsf and sand- to pebble-sized black clasts at $\sim 37$ mbsf (absolute maximum value $\mathrm{MS}=258 \times 10^{-5} \mathrm{SI}$; maximum MSP $=1929 \times 10^{-5} \mathrm{SI}$ )

Hole U1383E (Fig. F13) has four major peaks, and the maximum values for MSP differ slightly from those of MS (absolute maximum value MS $=167 \times$ $10^{-5} \mathrm{SI}$; maximum MSP $=351 \times 10^{-5} \mathrm{SI}$ ).

Hole U1382B (Fig. F14) has three major areas with peaks for MS and only two major areas for MSP. The shallower peak is absent in the MSP data because these sections were too disturbed and watery to be measured with the MSP sensor. The absolute maximum value of MS is $1660 \times 10^{-5} \mathrm{SI}$, and the maximum MSP is $2607 \times 10^{-5} \mathrm{SI}$. The peak area near $\sim 50 \mathrm{mbsf}$ is related to pebble-sized serpentinite clasts. Another secondary area with high values is located at the bottom of the borehole and is probably related to the presence of pebbles. 
Hole U1384A (Fig. F15) has higher MS and MSP values at the bottom of the borehole, where hard rocks are present. The absolute maxima for the hole are MS $=133 \times 10^{-5}$ SI and MSP $=317 \times 10^{-5}$ SI.

\section{Natural gamma radiation}

NGR was measured for all sediment cores at all sites, with the exception of portions of Hole U1383E that were not measured because of time constraints. Potassium concentrations were only calculated for Hole U1383D.

NGR and potassium concentration data for Hole U1383D obtained from the NGRL are summarized in Figure F16. The count time for each core section (30 min for sediment and $2 \mathrm{~h}$ for hard rock) was maximized to increase the accuracy of the values obtained. The total counts per second (cps) reflect the concentrations of all radioactive elements. Spectral data were recorded, and the counts per second for each channel indicate the abundance of a particular element. These values were related to a potassium (K) standard with known composition to calculate the $\mathrm{K}$ concentration in the core section. Total counts for whole rounds from Hole U1383D range from 0.05 to 77 cps once the background is subtracted (Fig. F16). Potassium concentration was calculated by using GRA bulk density as the effective density for the corrections.

No shipboard potassium data were produced by inductively coupled plasma-atomic emission spectrometry due to time constraints, and no downhole logging was conducted in these shallow holes for comparison. Potassium concentrations calculated from NGR range from $<0.01$ to $1.26 \mathrm{wt} \%$. The peak of potassium observed at $\sim 43.6$ mbsf (Section U1383D-6H-1) was cross-checked in the spectral data, and the most prominent signal for this element is present at this depth (Fig. F17). The higher concentrations of potassium near the seafloor may be due to Compton scattering from uranium. This element's radioactive daughters are relatively abundant in the shallowest section of the hole (see counts per second in Fig. F16).

NGR data from all sediment holes present a similar profile, with a peak close to the seafloor and a slight increase at the bottom of the deeper Holes U1382B and U1384A (Fig. F18). Hole U1383E NGR values range from 1.29 to $79 \mathrm{cps}$. In Hole U1382B, the values range from $<1$ to $85.6 \mathrm{cps}$, and in Hole U1384A they range from 0.12 to $76 \mathrm{cps}$.

\section{Formation factor}

Electrical conductivity was measured for Holes U1383D, U1382B, and U1384A and corrected based on standard measurements of electrical conductivity of the International Association for the Physical Sciences of the Oceans (IAPSO). Disturbed core samples and sandy areas were not measured. Formation factor was calculated for these sites.

Hole U1384D formation factors range from 1.76 to 2.77. with two peaks located at $\sim 6.8$ and $\sim 24.3$ mbsf. Below these peaks, formation factor values decrease with depth to the bottom of the borehole (Fig. F19).

Hole U1382B formation factors are lower, varying from 1.79 to 1.96. An increase in formation factor value is observed at $\sim 15.5$ mbsf. Below this depth, the values decrease and increase again below $\sim 80$ mbsf, reaching another maximum at the bottom of the borehole (Fig. F19).

Formation factor values for Hole U1384A range from 1.58 to 2.89. Maximum values correspond to a peak from $\sim 8$ to $\sim 12$ mbsf. A decrease in formation factor is observed from $\sim 12$ to $\sim 34$ mbsf. Below this depth, values present no major trend to the bottom of the borehole (Fig. F19).

\section{Moisture and density}

A summary of bulk density, dry density, grain density, void ratio, and porosity measurements on 172 discrete samples is presented in Table T6. These values were determined using IODP MAD Method C (see "Physical properties" in the "Methods" chapter [Expedition 336 Scientists, 2012a]). Samples were specifically selected to be representative of the core section from which they were taken. The values are consistent within the holes and correlate strongly with GRA bulk density measurements (Figs. F8, F9, F10, F11). All of the holes show a decrease in porosity and void ratio with depth in the top section of the borehole.

\section{Compressional $\boldsymbol{P}$-wave velocity}

$P$-wave velocity was measured with the WRMSL on cores from all sites. Additionally, caliper measurements were taken on the cores once they were split for the $x$-axis. For samples from Hole U1383D, measurements were also taken with the bayonet for the $y$ - and $z$-axes (Fig. F20). The results of the measurements are presented in Figures F20, F21, F22, and F23. When possible, the $P$-wave measurements were taken adjacent to the porosity (MAD) samples. In general, $x$-axis $P$-wave values are all higher than values obtained from the WRMSL. One reason for this increase could be that manually closing the caliper to take the measurement increased the compression on the sample. The values obtained are relatively close to values for seawater. Some of the intervals recovered did have a high fluid content, as indicated by the porosity values (Table T6). 


\section{Color reflectance spectroscopy}

Color reflectance was measured in all areas where the sediment was consolidated enough for the sensor to land. The analyzed sediment at all sites has only positive $a^{*}$ and $b^{*}$ values. The differences in color were mainly detected by changes in the range of the different color parameters and the scatter of the points. Holes U1383D (Fig. F24) and U1383E (Fig. F25) have the most uniform profiles. Holes U1382B (Fig. F26) and U1384A (Fig. F27) show greater variability with depth. The first two sections of Core 336-U1382A-3H were too disturbed and watery for measurements to be made. A summary of the values obtained is given in Table T7.

\section{APCT-3 temperature measurements}

Downhole temperature measurements were attempted with the APCT-3 in Hole U1382B on Cores 336U1382B-3H through $5 \mathrm{H}$ at $24.5,34$, and $43.5 \mathrm{mbsf}$, respectively. The measurements were suspended for deeper cores because of poor recovery, which we suspected was caused by the extra time the core was left in the formation in order to provide sufficient data to extrapolate to in situ temperatures. However, the cores contained coarse sand-sized to pebble-sized rock fragments, which might also have caused the poor core recovery. Unfortunately, the temperature data quality for the three attempts was poor, owing to motion of the coring shoe in weak, shallow sediments that apparently also contributed to poor recovery. The raw temperature-time records for the three attempts (Fig. F28) show evidence of motion of the corer during the measurement period, with indications for multiple disturbances involving mixing of fluids from above or multiple penetrations of the probe in the formation beneath the bit. As a result, none of the data fit well to the numerical model (TPFit) that represents the ideal decay of the frictional heating pulse on penetration of the coring shoe, and large errors are associated with all attempts to use this model to extrapolate to apparent in situ temperatures. The results seem to be consistent with in situ temperatures of $3^{\circ}-3.6^{\circ} \mathrm{C}$ at all three measurement points, but the large error ranges in the fits provide no confidence that the measurements actually resolve an in situ temperature gradient with any accuracy.

\section{References}

Bach, W., Garrido, C.J., Paulick, H., Harvey, J., and Rosner, M., 2004. Seawater-peridotite interactions: first insights from ODP Leg 209, MAR $15^{\circ}$ N. Geochem., Geophys., Geosyst., 5(9):Q09F26. doi:10.1029/2004GC000744
Boschi, C., Früh-Green, G.L., and Escartín, J., 2006. Occurrence and significance of serpentinite-hosted, talc- and amphibole-rich fault rocks in modern oceanic settings and ophiolite complexes: an overview. Ofioliti, 31(2):129-140. http://www.ofioliti.it/index.php/ ofioliti/article/view/335

Bouma, A.H., 1962. Sedimentology of Some Flysch Deposits: A Graphic Approach to Facies Interpretation: Amsterdam (Elsevier).

Expedition 336 Scientists, 2012a. Methods. In Edwards, K.J., Bach, W., Klaus, A., and the Expedition 336 Scientists, Proc. IODP, 336: Tokyo (Integrated Ocean Drilling Program Management International, Inc.). doi:10.2204/iodp.proc.336.102.2012

Expedition 336 Scientists, 2012b. Site U1382. In Edwards, K.J., Bach, W., Klaus, A., and the Expedition 336 Scientists, Proc. IODP, 336: Tokyo (Integrated Ocean Drilling Program Management International, Inc.). doi:10.2204/iodp.proc.336.104.2012

Expedition 336 Scientists, 2012c. Site U1383. In Edwards, K.J., Bach, W., Klaus, A., and the Expedition 336 Scientists, Proc. IODP, 336: Tokyo (Integrated Ocean Drilling Program Management International, Inc.). doi:10.2204/iodp.proc.336.105.2012

Harigane, Y., Michibayashi, K., and Ohara, Y., 2011. Relicts of deformed lithospheric mantle within serpentinites and weathered peridotites from the Godzilla Megamullion, Parece Vela back-arc basin, Philippine Sea. Isl. Arc, 20(2):174-187. doi:10.1111/j.1440-1738.2011.00759.x

Hirauchi, K., and Yamaguchi, H., 2007. Unique deformation processes involving the recrystallization of chrysotile within serpentinite: implications for aseismic slip events within subduction zones. Terra Nova, 19(6):454461. doi:10.1111/j.1365-3121.2007.00771.x

Hirauchi, K., Michibayashi, K., Ueda, H., and Katayama, I., 2010. Spatial variations in antigorite fabric across a serpentinite subduction channel: insights from the Ohmachi Seamount, Izu-Bonin frontal arc. Earth Planet. Sci. Lett., 299(1-2):196-206. doi:10.1016/j.epsl.2010.08.035

Jarrard, R.D., and Kerneklian, M.J., 2007. Data report: physical properties of the upper oceanic crust of ODP Site 1256: multisensor track and moisture and density measurements. In Teagle, D.A.H., Wilson, D.S., Acton, G.D., and Vanko, D.A. (Eds.), Proc. ODP, Sci. Results, 206: College Station, TX (Ocean Drilling Program), 1-11. doi:10.2973/odp.proc.sr.206.011.2007

McDuff, R.E., 1985. The chemistry of interstitial waters, Deep Sea Drilling Project Leg 86. In Heath, G.R., Burckle, L.H., et al., Init. Repts. DSDP, 86: Washington, DC (U.S. Govt. Printing Office), 675-687. doi:10.2973/ dsdp.proc.86.131.1985

Mével, C., 2003. Serpentinization of abyssal peridotites at mid-ocean ridges. C. $R$. Geosci., 335(10-11):825-852. doi:10.1016/j.crte.2003.08.006

Michibayashi, K., Ohara, Y., Stern, R.J., Fryer, P., Kimura, J.I., Tasaka, M., Harigane, Y., and Ishii, T., 2009. Peridotites from a ductile shear zone within back-arc lithospheric mantle, southern Mariana Trench: results of a Shinkai 6500 dive. Geochem., Geophys., Geosyst., 10(5):Q05X06. doi:10.1029/2008GC002197 
Shipboard Scientific Party, 1979. Site 395: $23^{\circ} \mathrm{N}$, MidAtlantic Ridge. In Melson, W.G., Rabinowitz, P.D., et al., Init. Repts. DSDP, 45: Washington, DC (U.S. Govt. Printing Office), 131-264. doi:10.2973/dsdp.proc.45.107.1979

Shipboard Scientific Party, 1998. Site 1074. In Becker, K., Malone, M.J., et al., Proc. ODP, Init. Repts., 174B: College Station, TX (Ocean Drilling Program), 25-35. doi:10.2973/odp.proc.ir.174B.103.1998

Timofeev, P.P., Varentsov, I.M., Rateev, M.A., and Renngarten, N.V., 1979. Lithology, mineralogy, and geochemistry of upper Cenozoic sediments at $23^{\circ} \mathrm{N}$ near the MidAtlantic Ridge, drilled on Leg 45. In Melson, W.G., Rabi- nowitz, P.D., et al., Init. Repts. DSDP, 45: Washington, DC (U.S. Govt. Printing Office), 323-347. doi:10.2973/ dsdp.proc.45.111.1979

Ziebis, W., McManus, J., Ferdelman, T., Schmidt-Schierhorn, F., Bach, W., Muratli, J., Edwards, K.J., and Villinger, H., 2012. Interstitial fluid chemistry of sediments underlying the North Atlantic Gyre and the influence of subsurface fluid flow. Earth Planet. Sci. Lett., 323324:79-91. doi:10.1016/j.epsl.2012.01.018

Publication: 16 November 2012 MS 336-106 
Figure F1. Map showing location of four holes where sediments were cored (Holes U1382B, U1384A, U1383E, and U1383D).

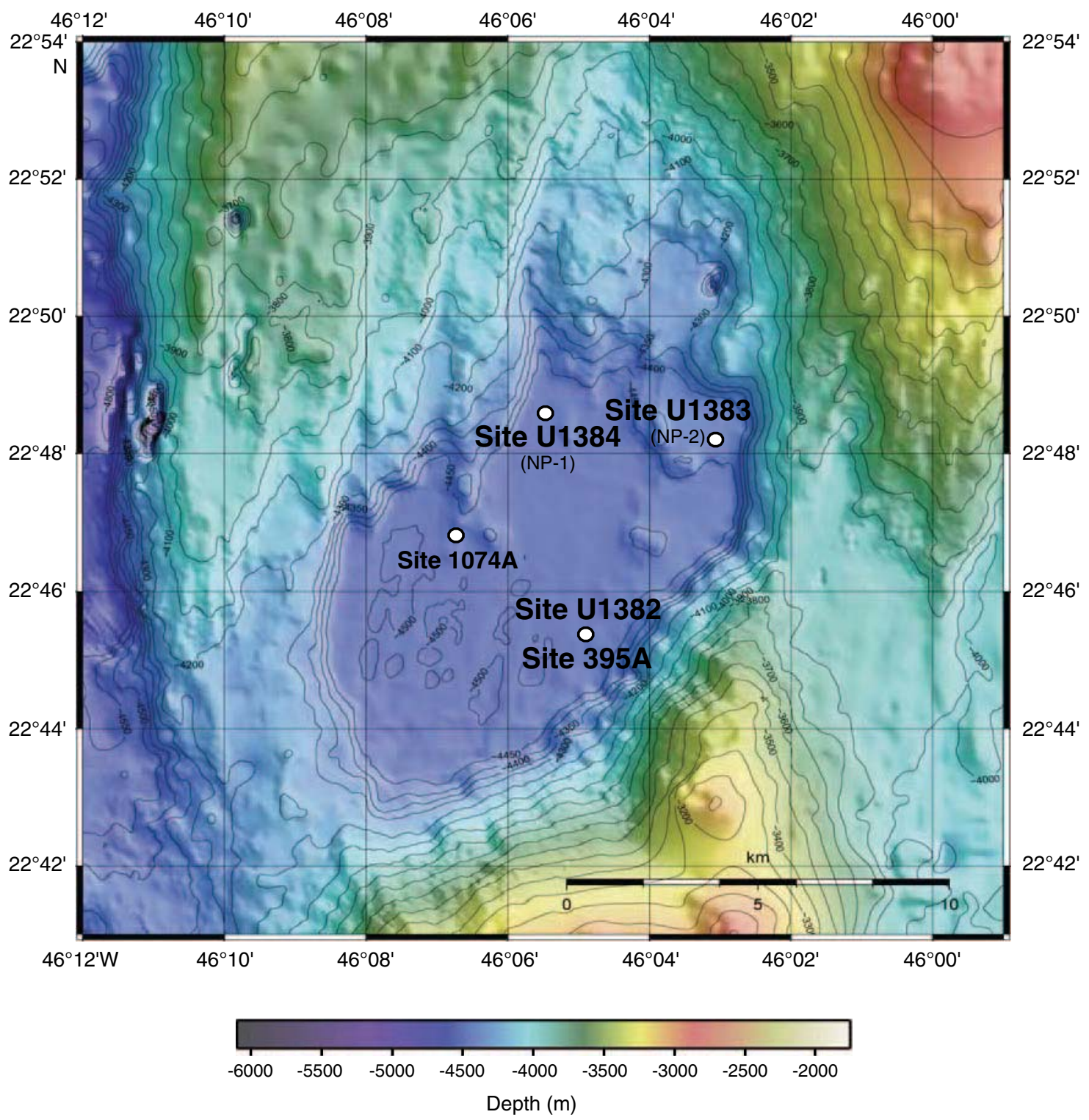


Figure F2. Section-Half Imaging Logger (SHIL) image of recovered serpentinites. A. Section 336-U1382B-12X-1 (Piece 1). B. Section 336-U1382B-12X-1 (Piece 2). C. Section 336-U1382B-12X-1 (Piece 3). D. Section 336U1382B-12X-1 (Piece 4).
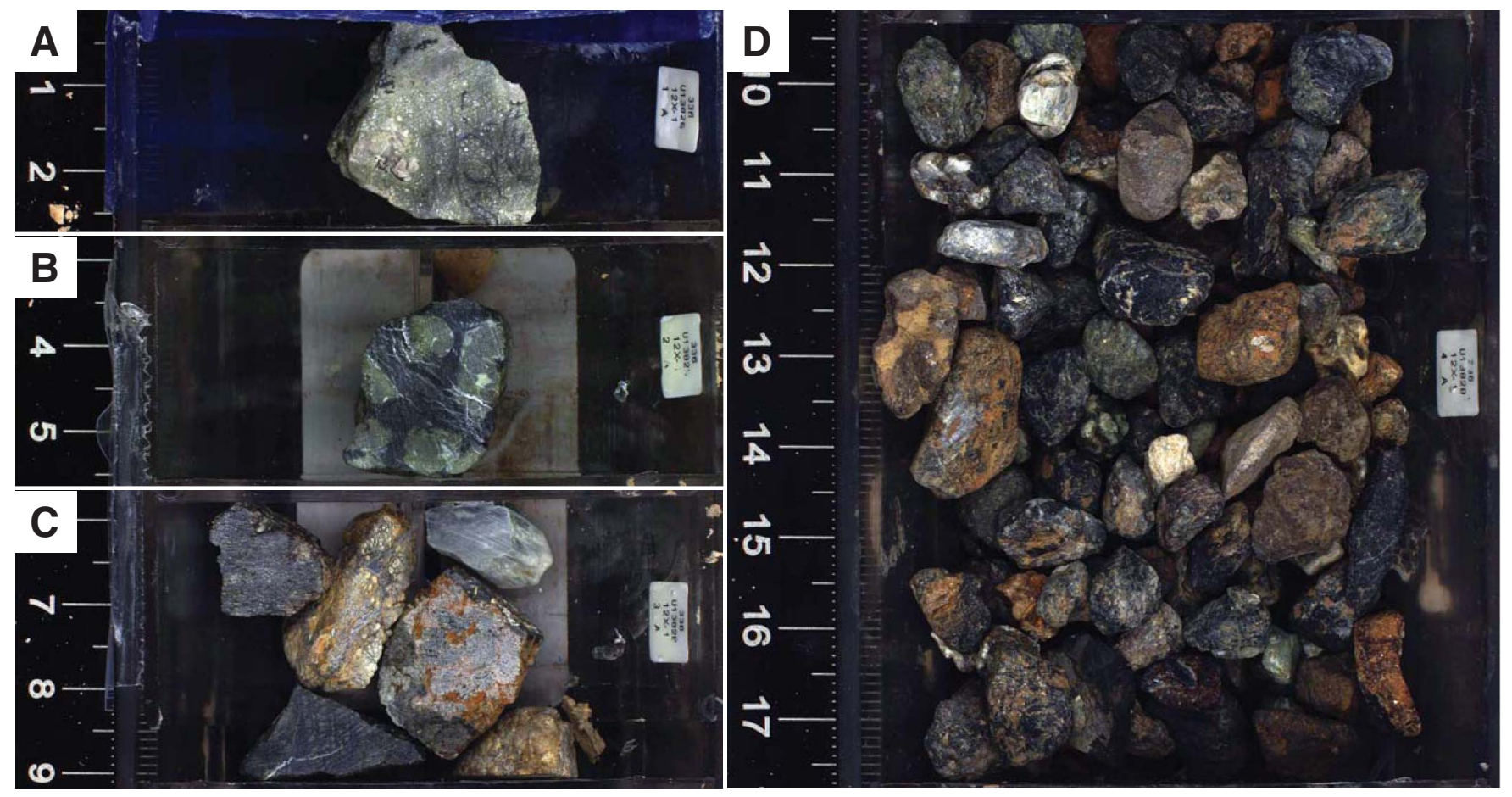
Figure F3. Section-Half Imaging Logger (SHIL) image of troctolite and serpentinite clasts in the sedimentary sequence of Hole U1382B. A. Interval 336-U1382B-6H-7, 53-58 cm. B. Interval 336-U1382B-6H-8, 45-53 cm. C. Interval 336-U1382B-7H-1, 0-4 cm.
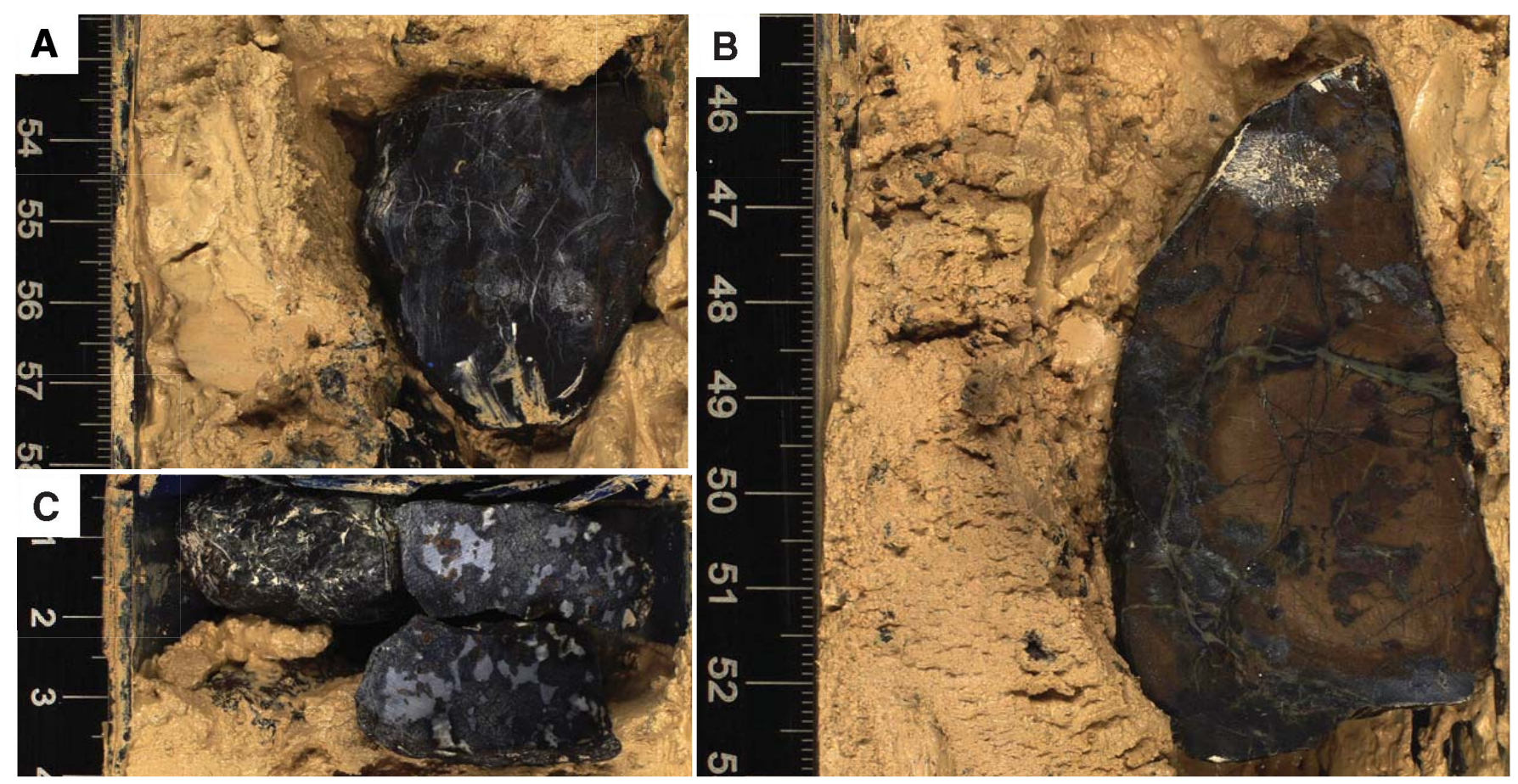
Figure F4. Section-Half Imaging Logger (SHIL) image of aphyric basalt with cryptocrystalline groundmass and brown alteration halo lining a vertical vein (interval 336-U1383D-7X-CC, 28-39 cm [Piece 5]).

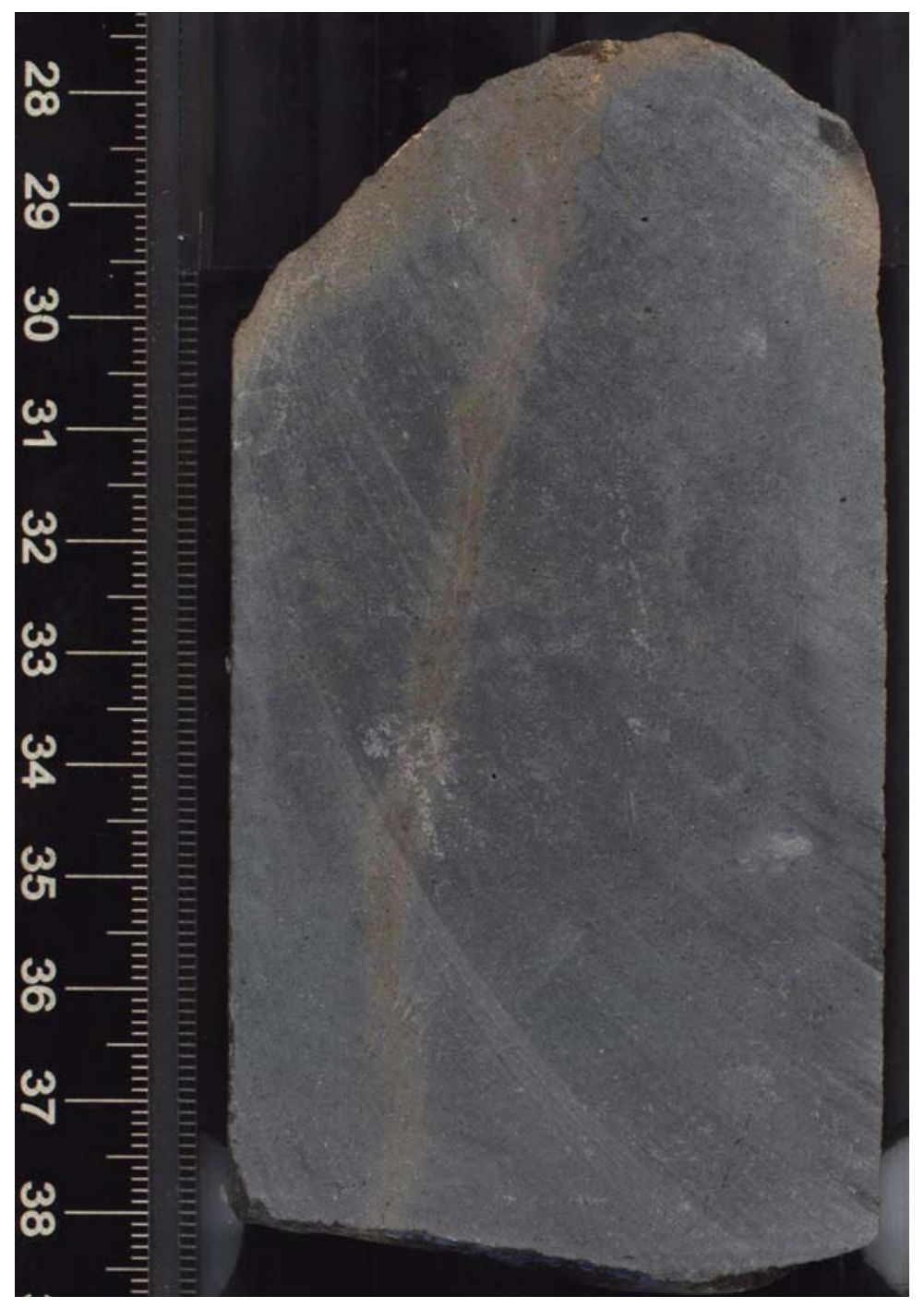


Figure F5. Sedimentary breccia from Section 336-U1383D-7X-CC. A. Section-Half Imaging Logger (SHIL) image of sediment breccia composed of poorly shorted angular clasts of palagonitized glass in light brown sedimentary matrix (clayey chalk) (interval 336-U1383D-7X-CC, 57-59 cm [Piece 10]). The breccias occur in contact with glassy pillow margins of sparsely vesicular aphyric basalt. B. Close-up photograph showing concentric and mottled alteration texture of palagonitized glass clasts and beige-colored micritic cement at the contact between the basalt and brecciated domain.
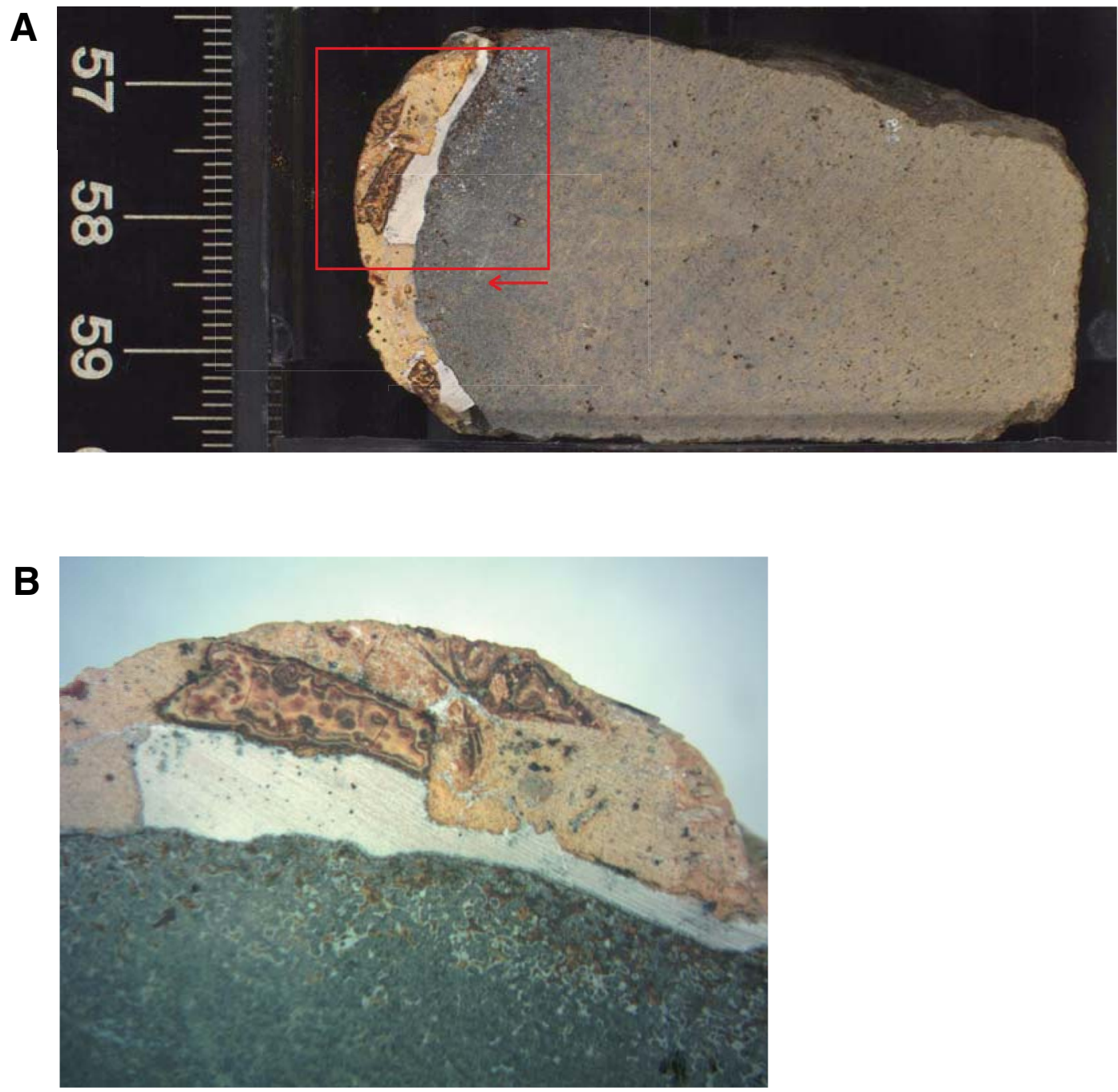
Figure F6. Section-Half Imaging Logger (SHIL) image of aphyric basalt with cryptocrystalline groundmass and brown alteration halo lining the contact with light brown sediment (interval 336-U1384A-12X-1, 13-19 cm [Piece 11]).

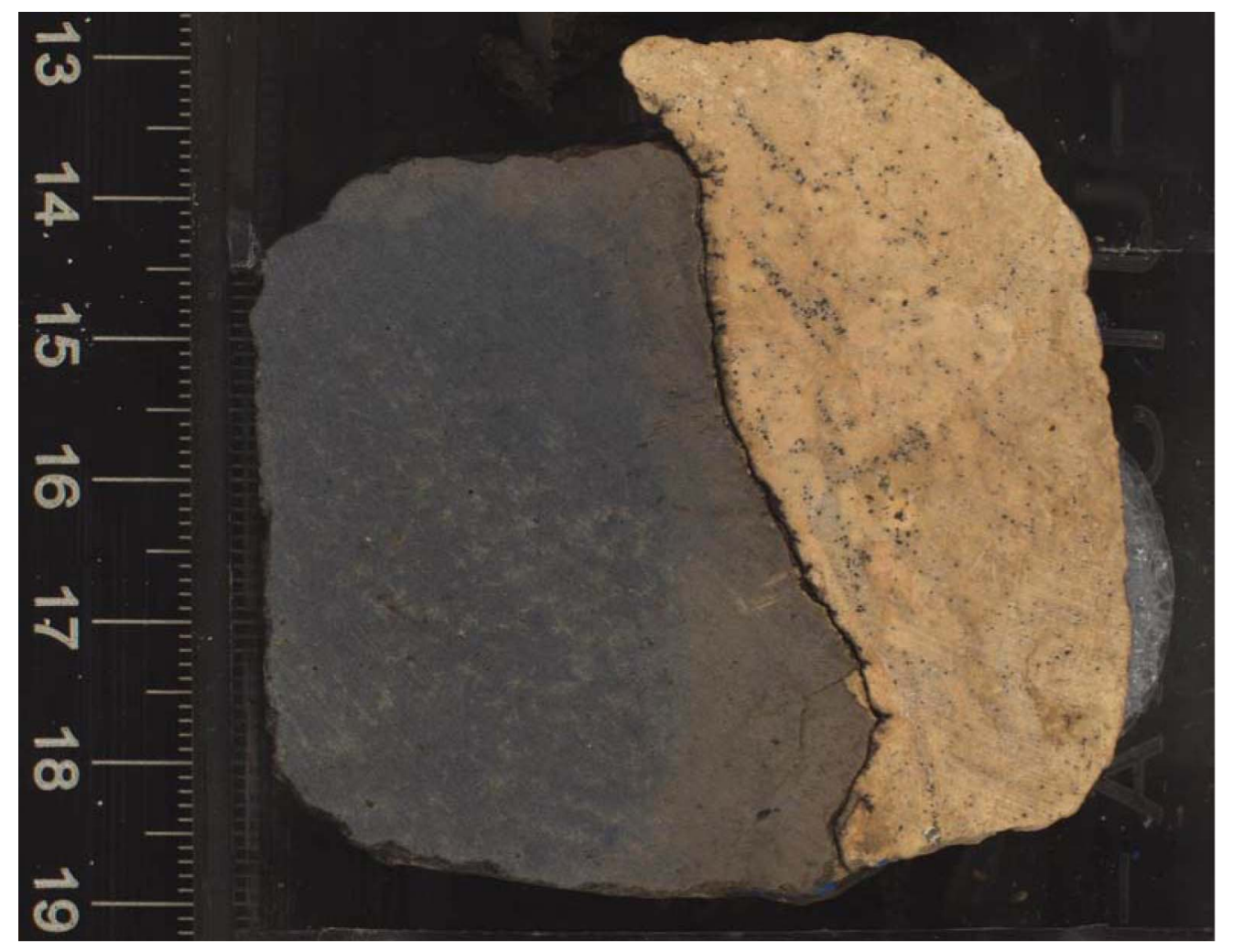


Figure F7. Plots of pore water nitrate, chlorinity, $\mathrm{Mg}, \mathrm{Mn}, \mathrm{Mo}$, and $\mathrm{Ba}$.
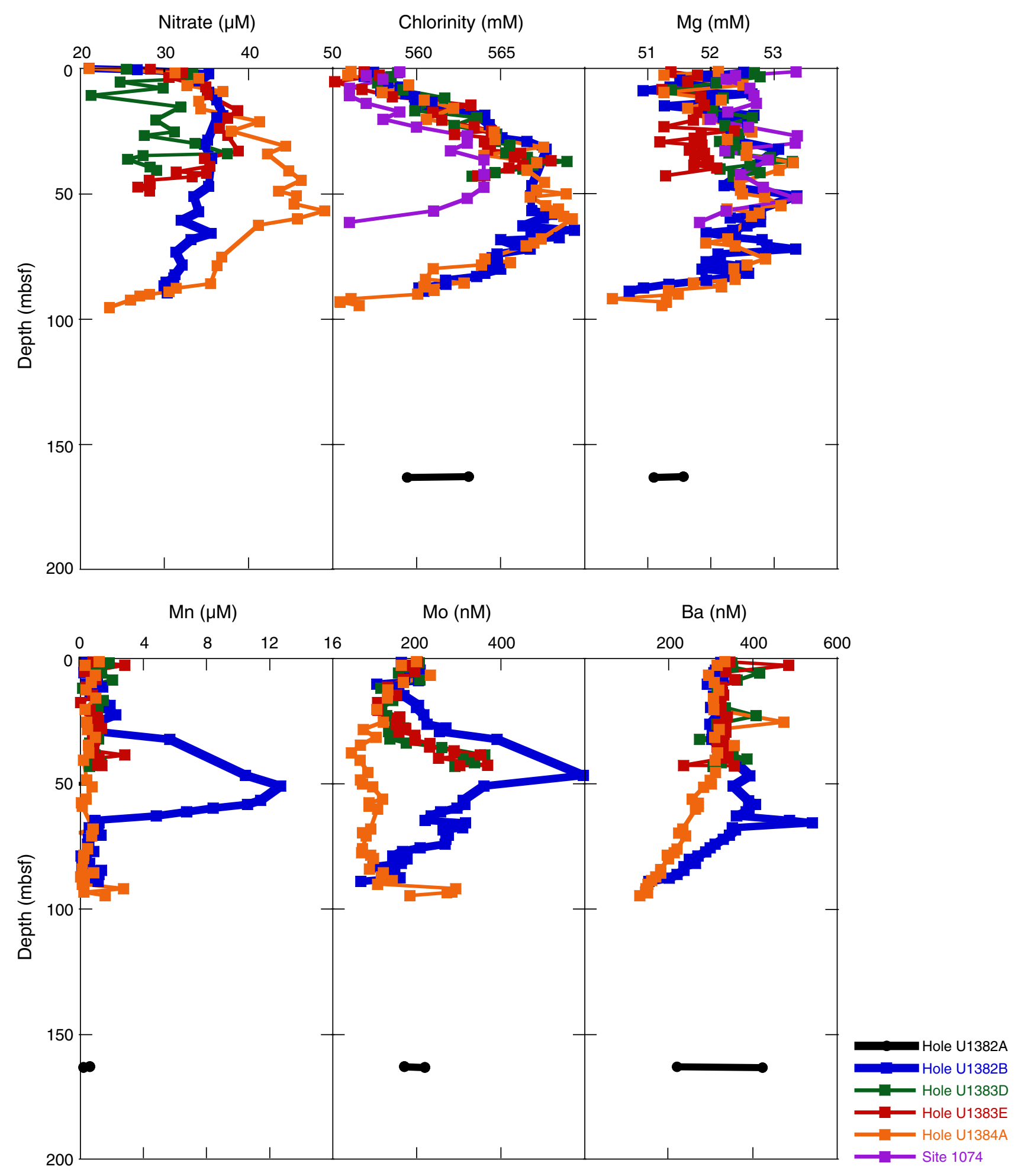
Figure F8. Plots of gamma ray attenuation (GRA) density and moisture and density (MAD) measurements, Hole U1383D. A. GRA bulk density and MAD density from discrete measurements. Shades of gray indicate levels of filtered data. B. Bulk, dry, and grain densities calculated for discrete samples. C. Porosity. D. Void ratio.

A Bulk density $\left(\mathrm{g}^{\mathrm{cm}} \mathrm{cm}^{3}\right.$ B

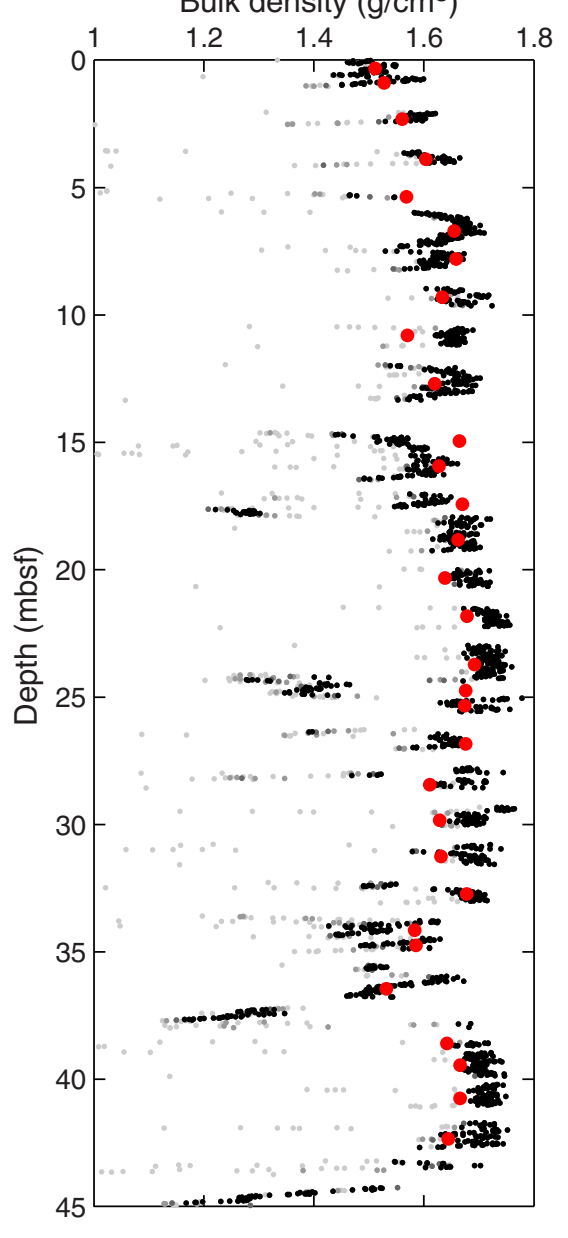

- MAD bulk density

- GRA bulk density (filtered)

- GRA bulk density (second filter)

- GRA bulk density (first filter)

- GRA bulk density (unfiltered)

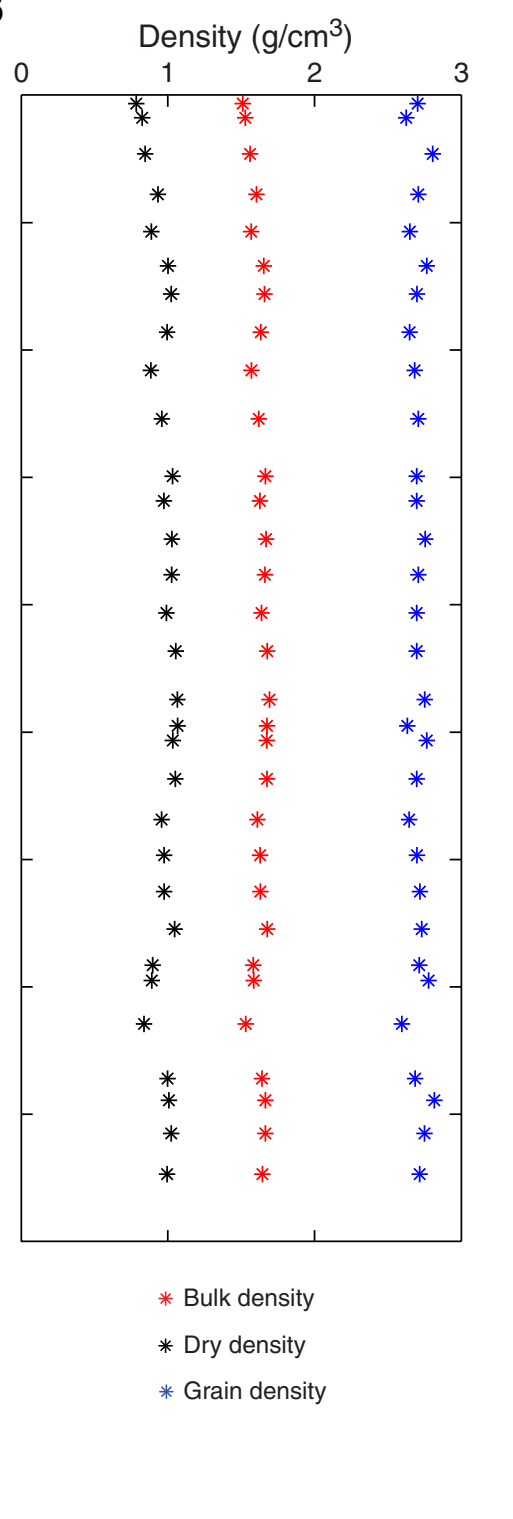

C

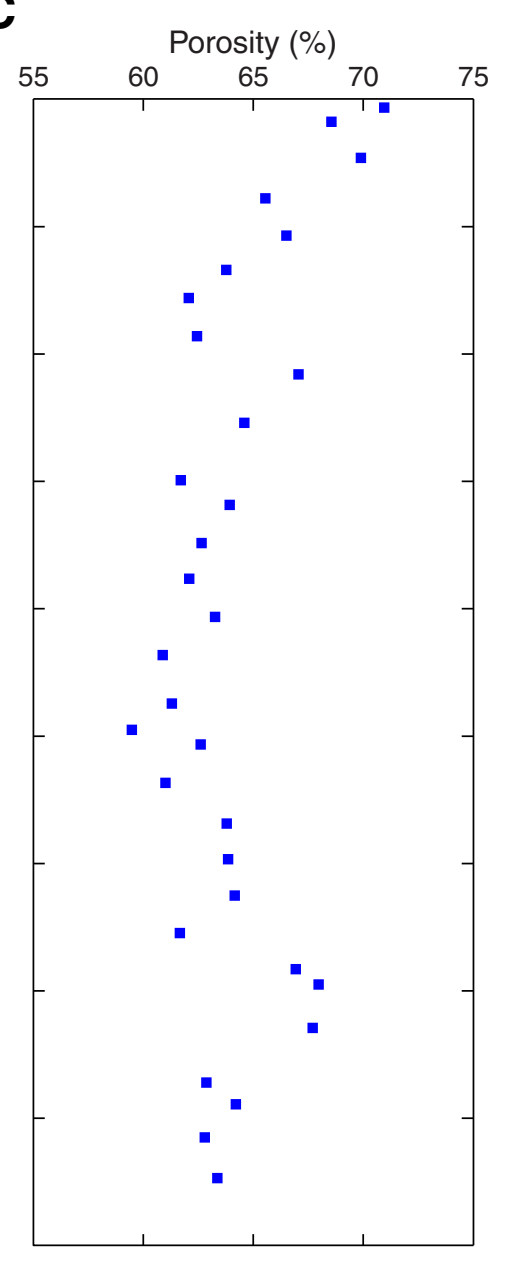

D

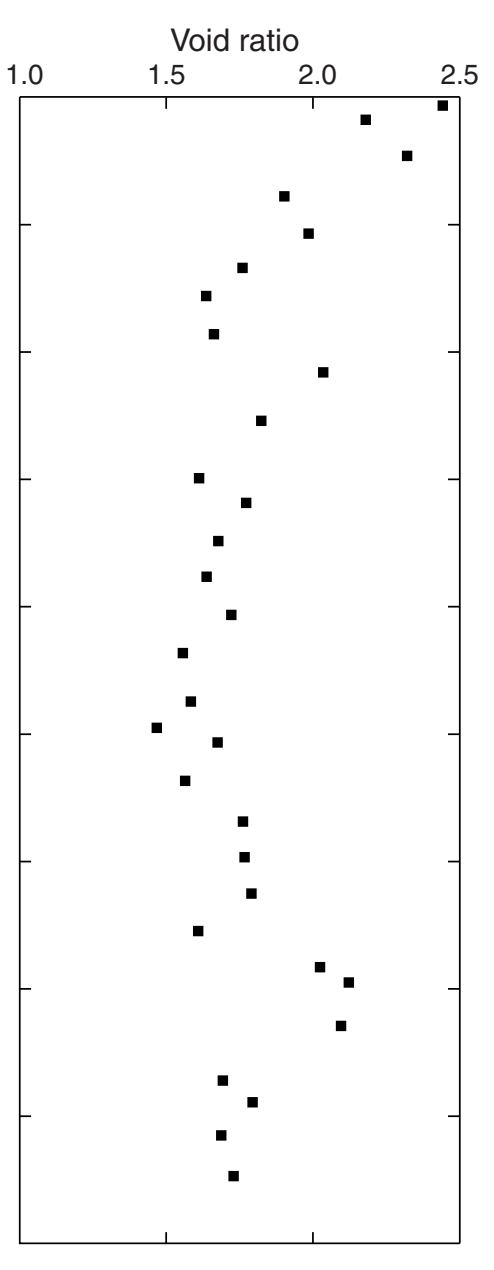


Figure F9. Plots of gamma ray attenuation (GRA) density and moisture and density (MAD) measurements, Hole U1383E. A. GRA bulk density and MAD density from discrete measurements. Shades of gray indicate levels of filtered data. B. Bulk, dry, and grain densities calculated for discrete samples. C. Porosity. D. Void ratio.

A

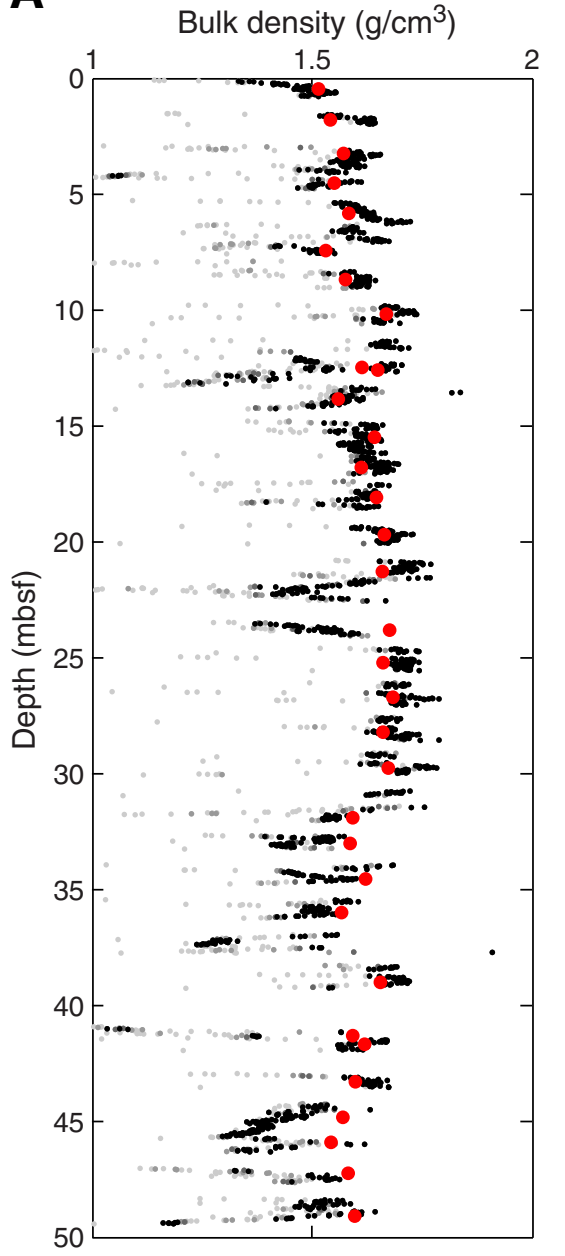

- MAD bulk density

- GRA bulk density (filtered)

- GRA bulk density (second filter)

- GRA bulk density (first filter)

- GRA bulk density (unfiltered)
B

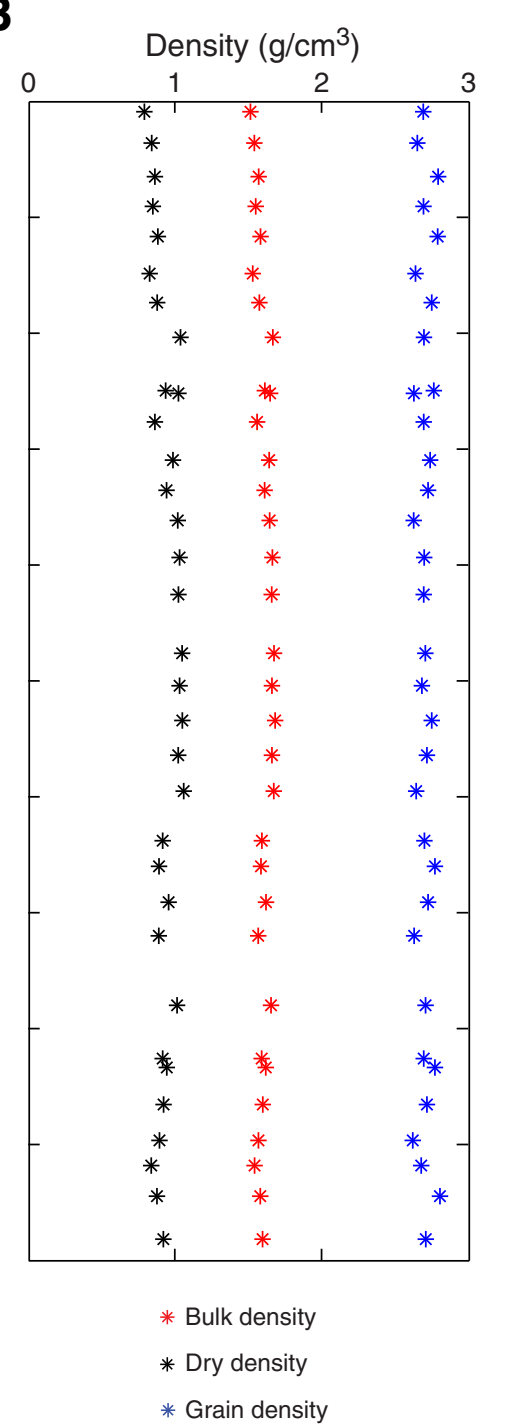

C

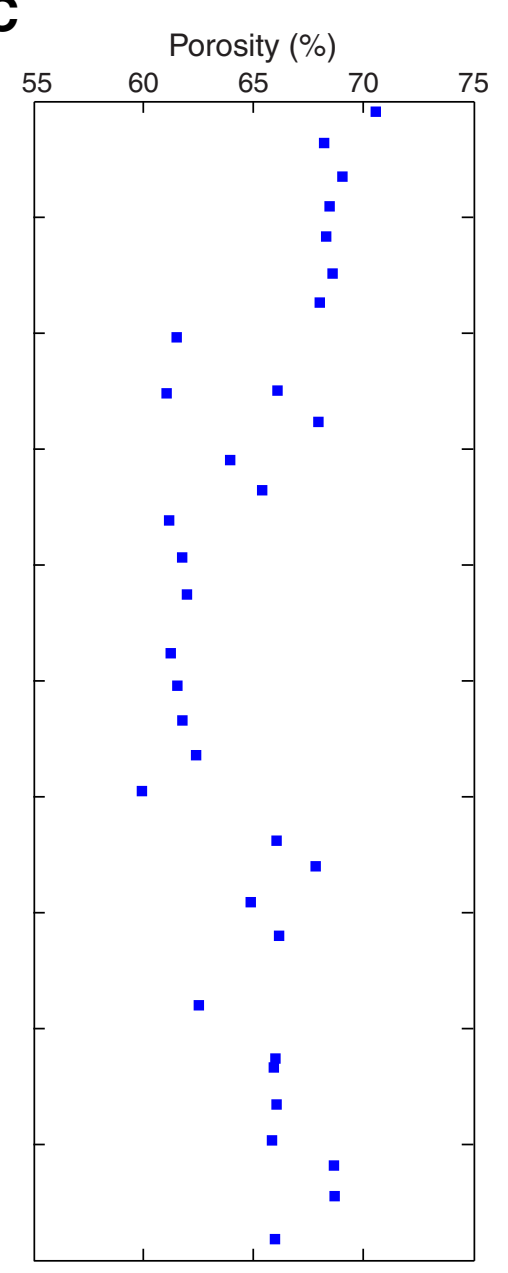

D

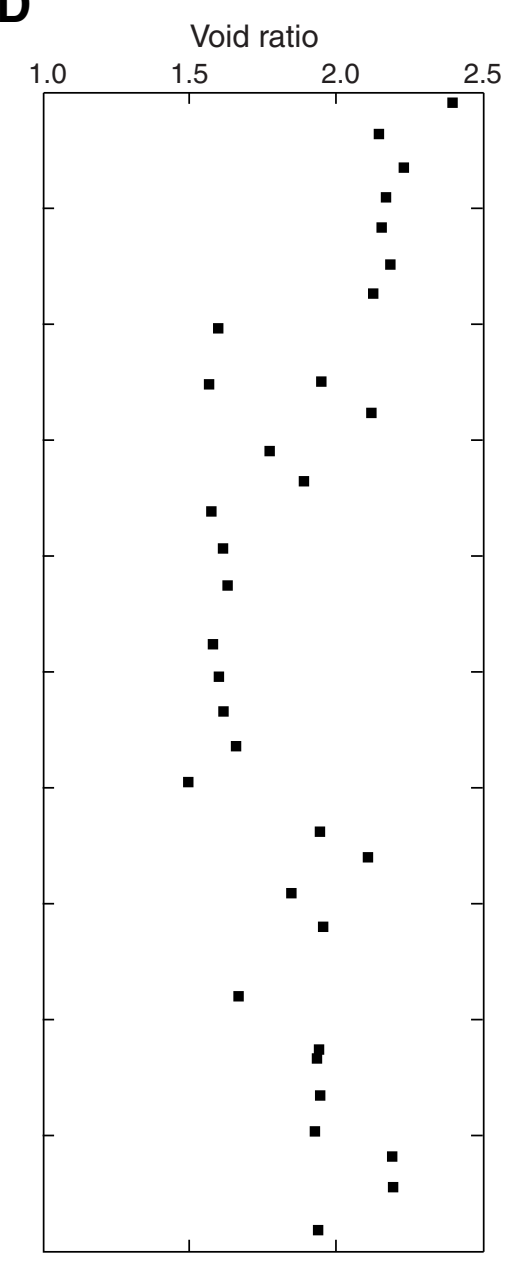


Figure F10. Plots of gamma ray attenuation (GRA) density and moisture and density (MAD) measurements, Hole U1382B. A. GRA bulk density and MAD density from discrete measurements. Shades of gray indicate levels of filtered data. B. Bulk, dry, and grain densities calculated for discrete samples. C. Porosity. D. Void ratio.

A

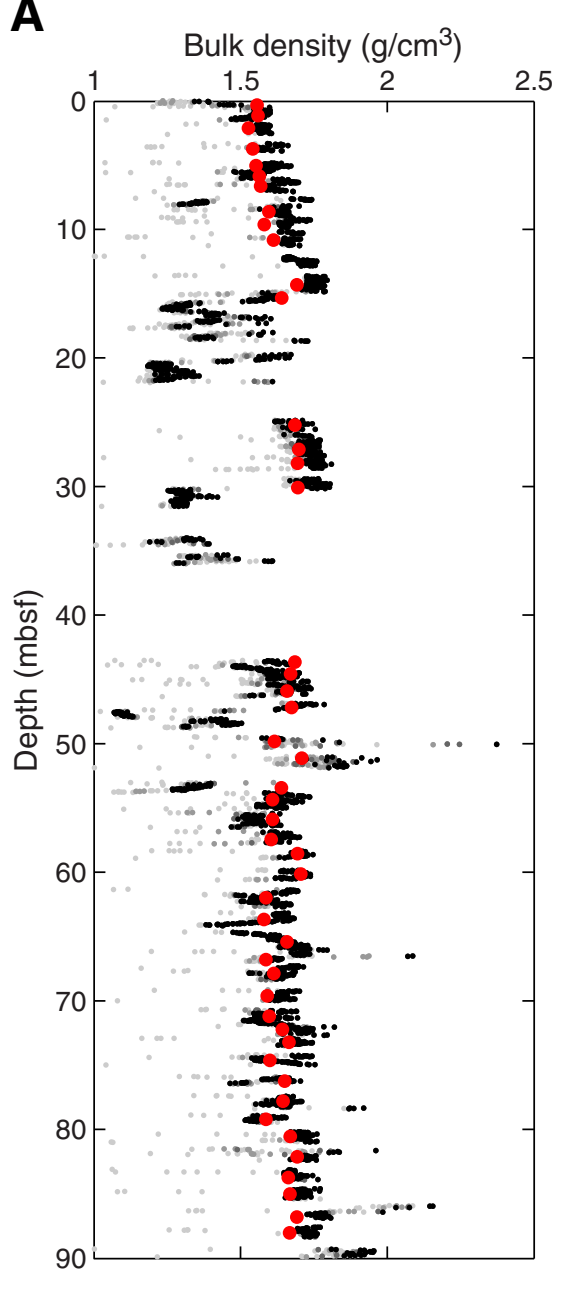

- MAD bulk density

- GRA bulk density (filtered)

- GRA bulk density (second filter)

- GRA bulk density (first filter)

- GRA bulk density (unfiltered)
B

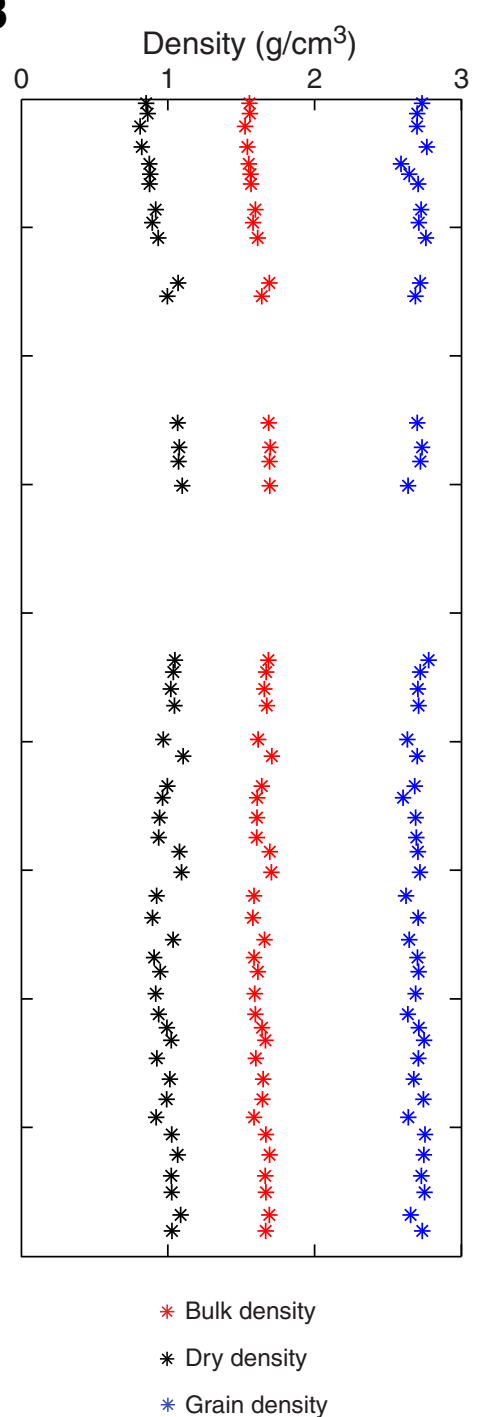

C

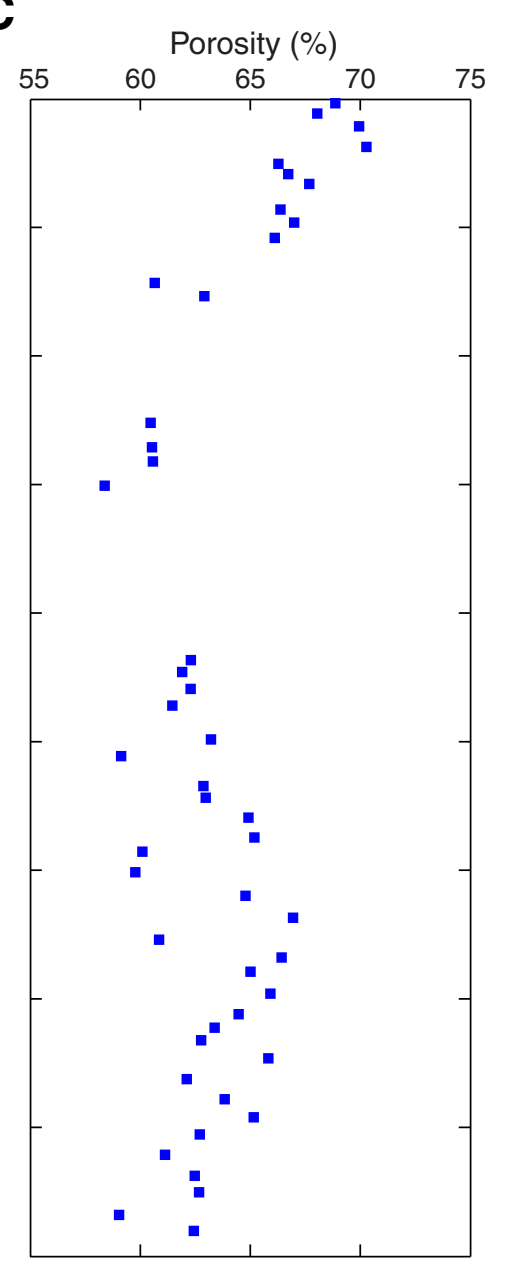

D

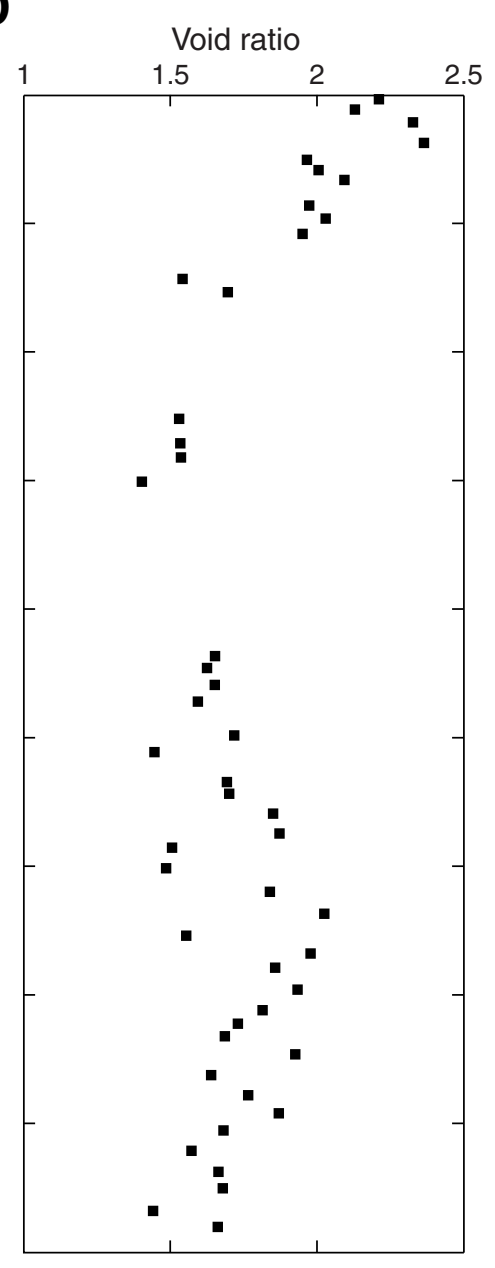


Figure F11. Plots of gamma ray attenuation (GRA) density and moisture and density (MAD) measurements, Hole U1384A. A. GRA bulk density and MAD density from discrete measurements. Shades of gray indicate levels of filtered data. B. Bulk, dry, and grain densities calculated for discrete samples. C. Porosity. D. Void ratio.

A

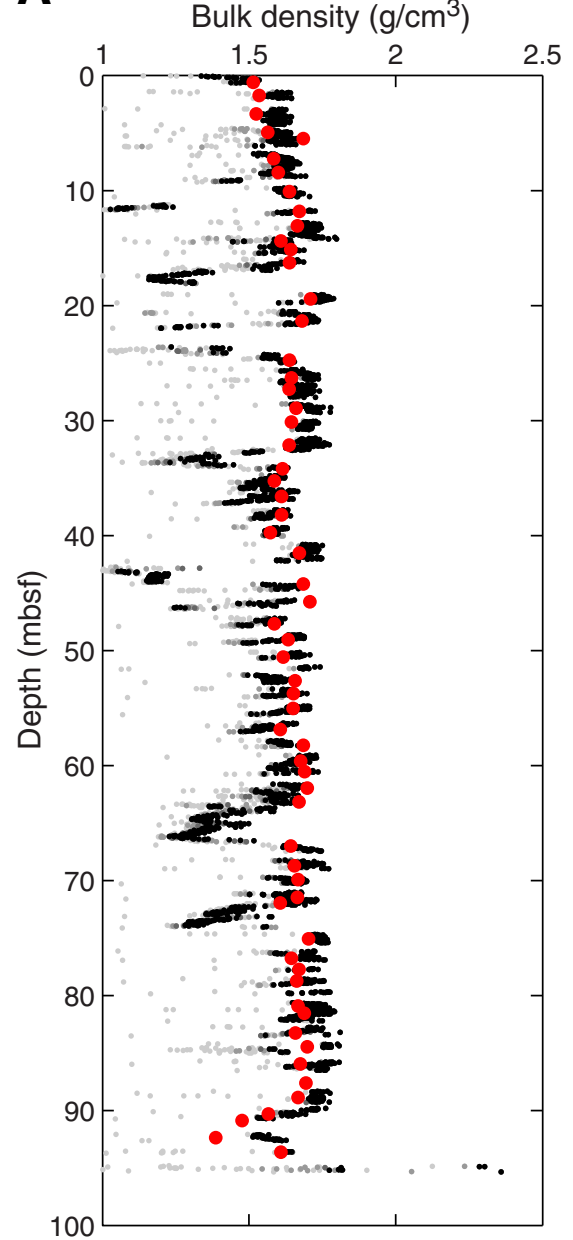

- MAD bulk density

- GRA bulk density (filtered)

- GRA bulk density (second filter)

- GRA bulk density (first filter)

- GRA bulk density (unfiltered)
B

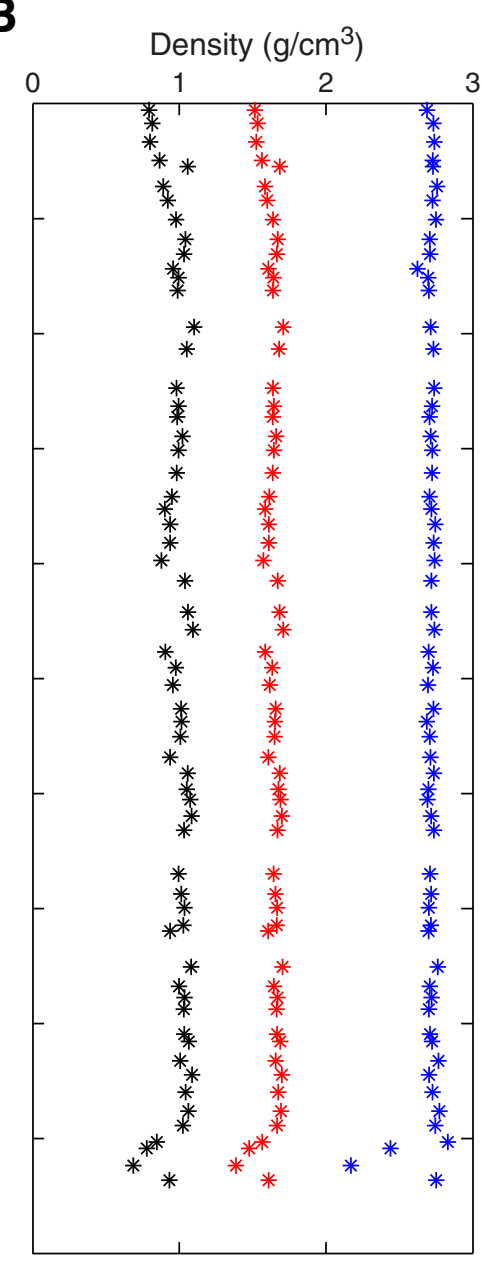

* Bulk density

* Dry density

* Grain density
C

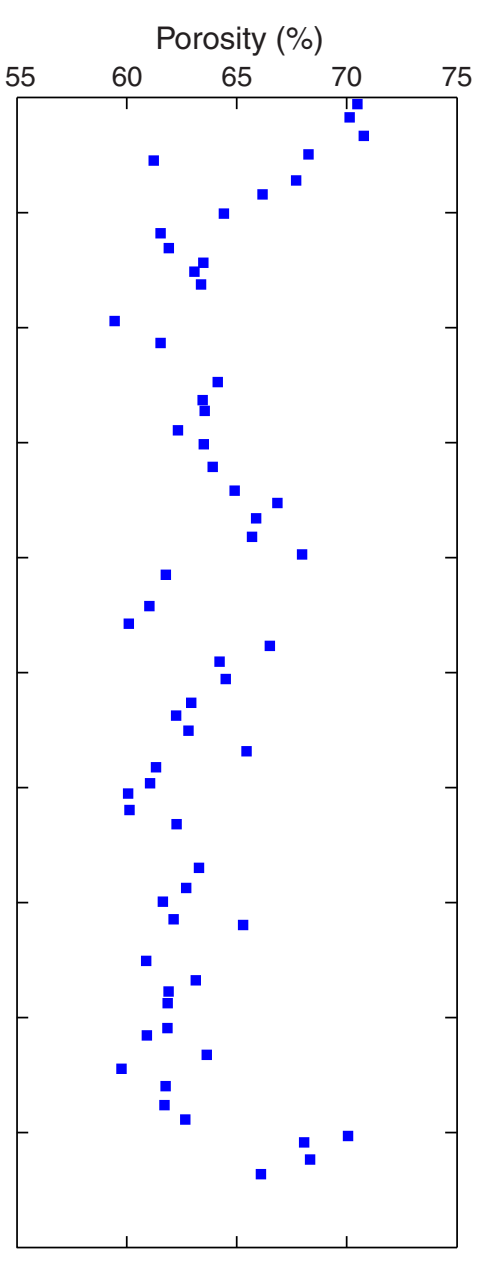

D

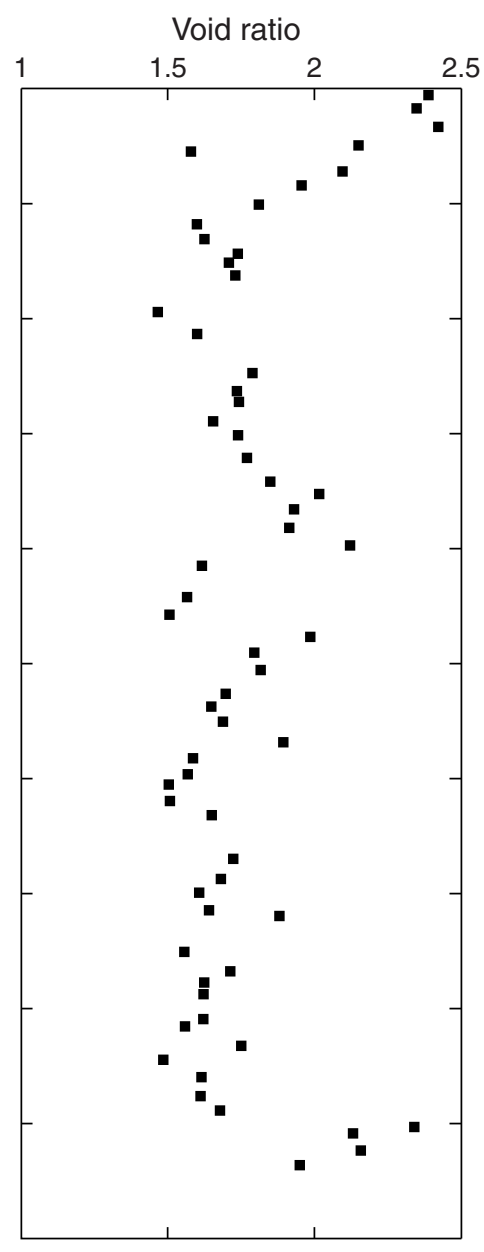


Figure F12. Plots of WRMSL whole-round and SHMSL point magnetic susceptibility, Hole U1383D.

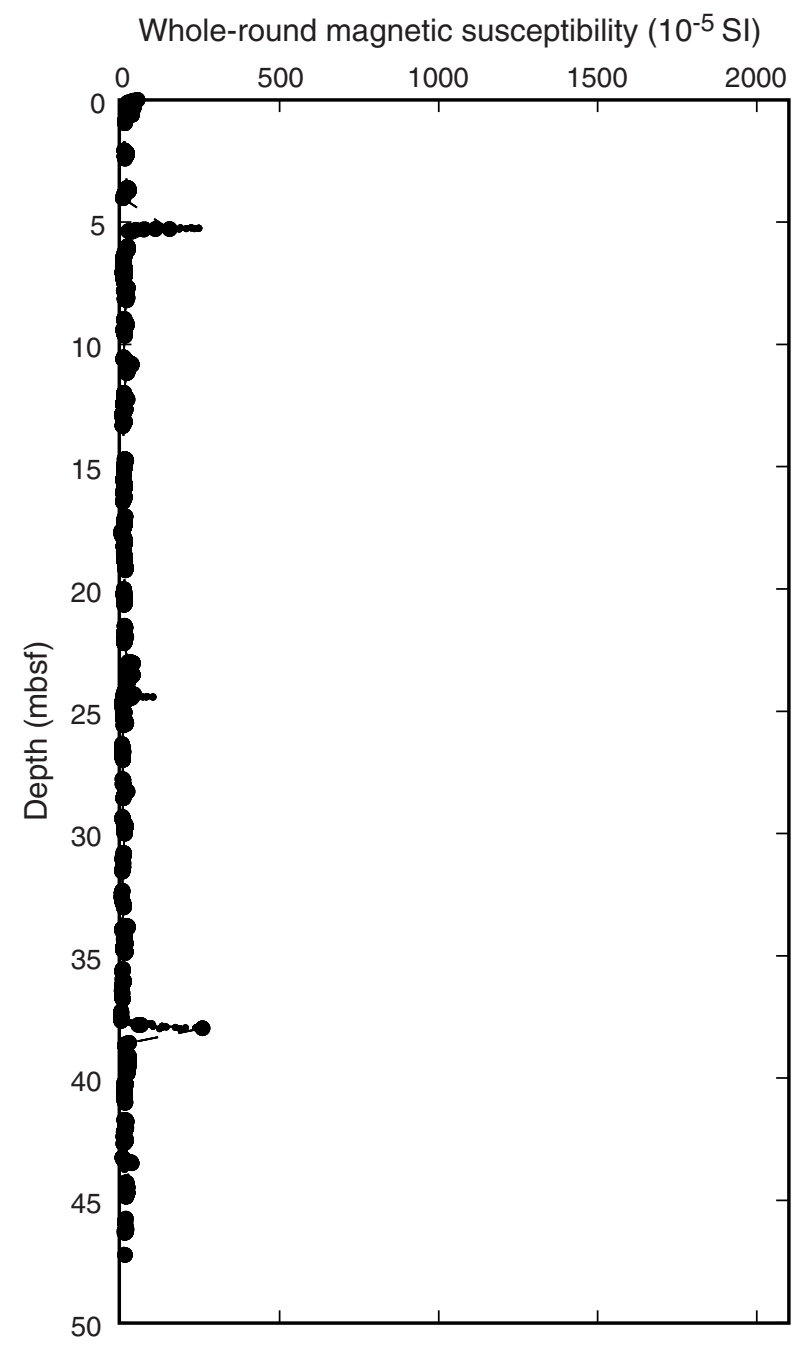

Point magnetic susceptibility $\left(10^{-5} \mathrm{SI}\right)$

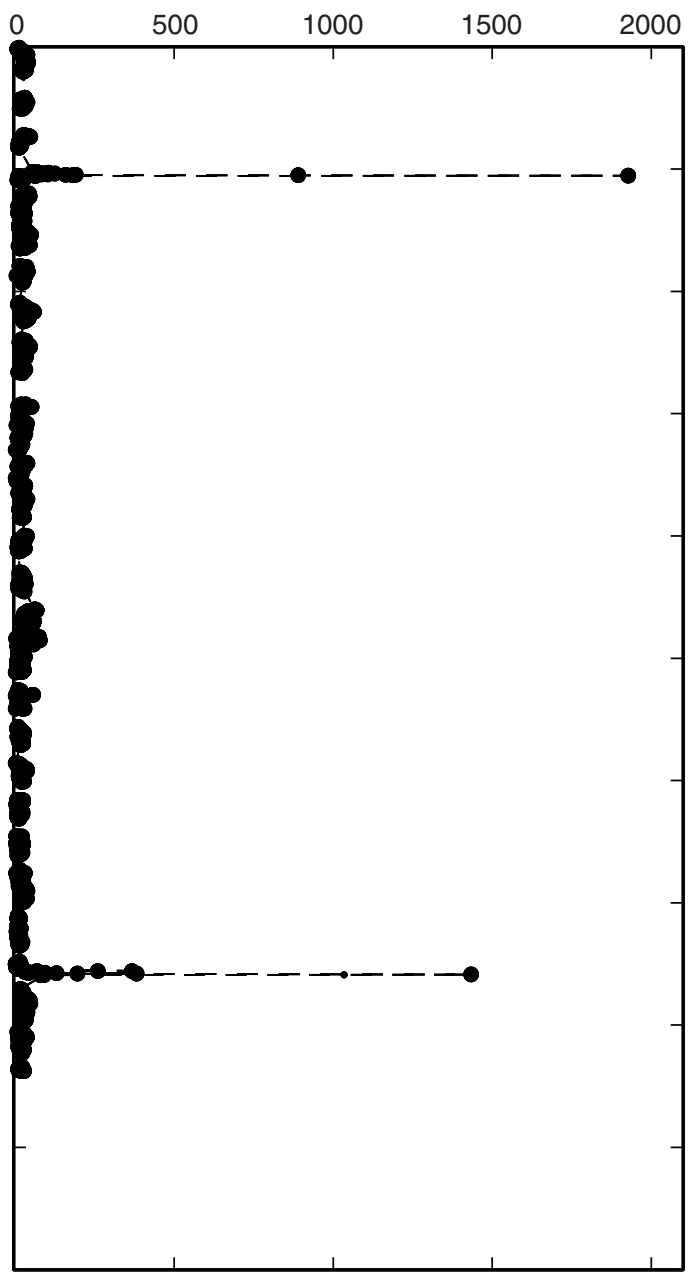



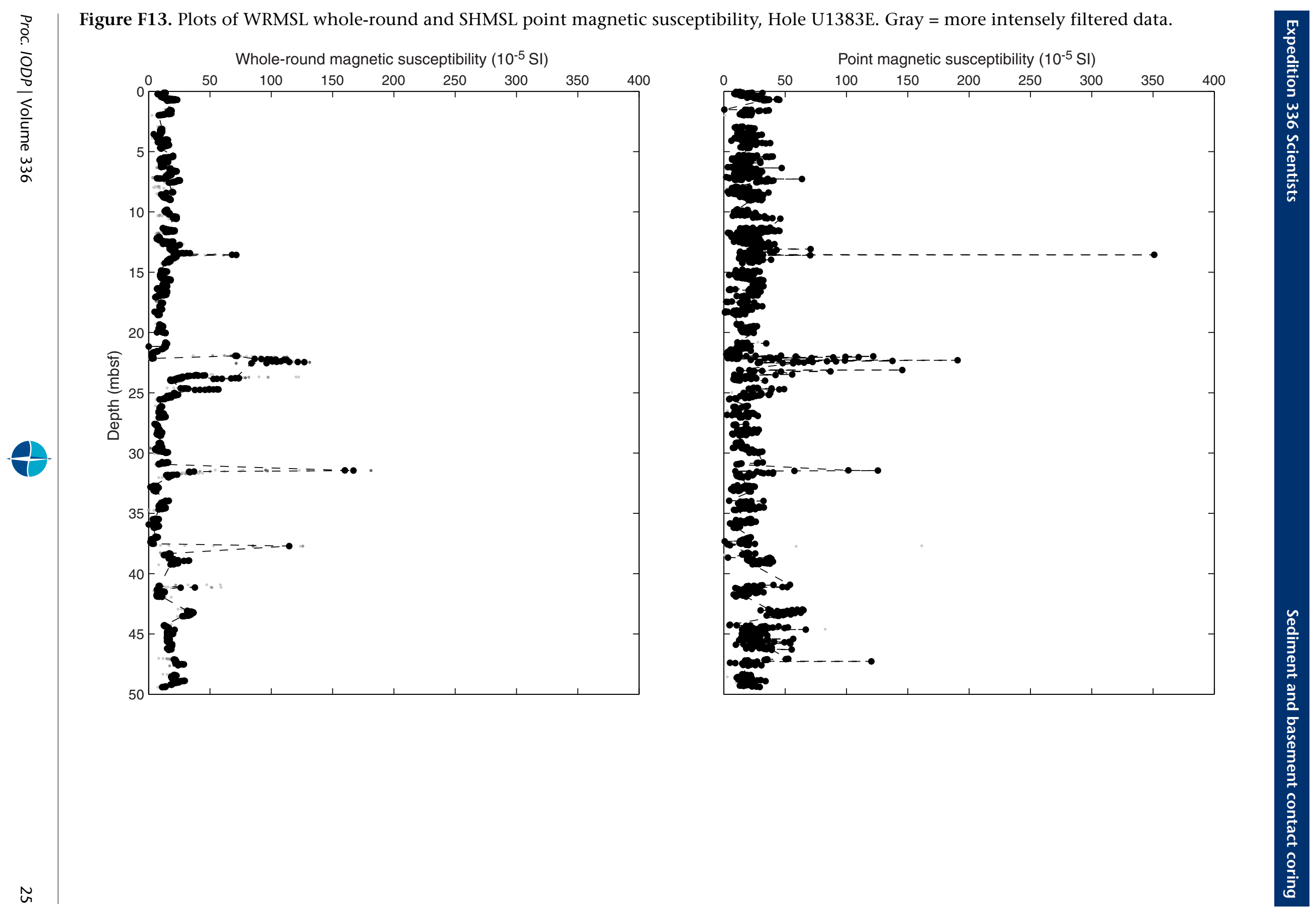

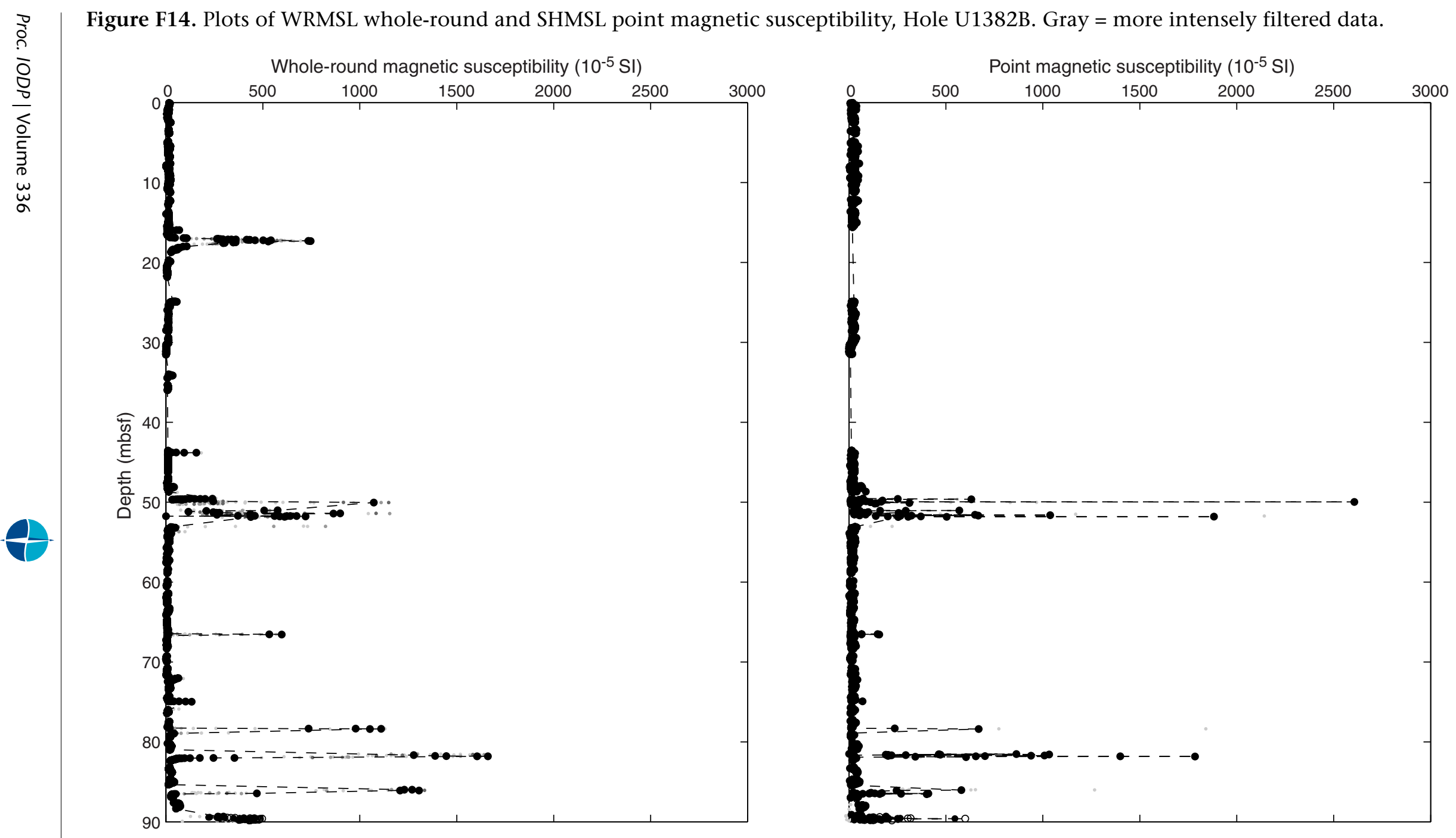

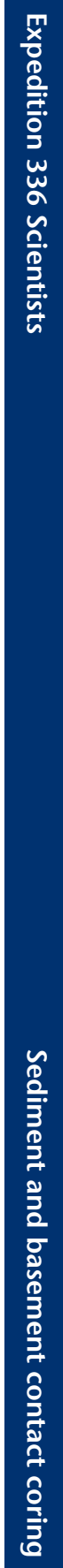



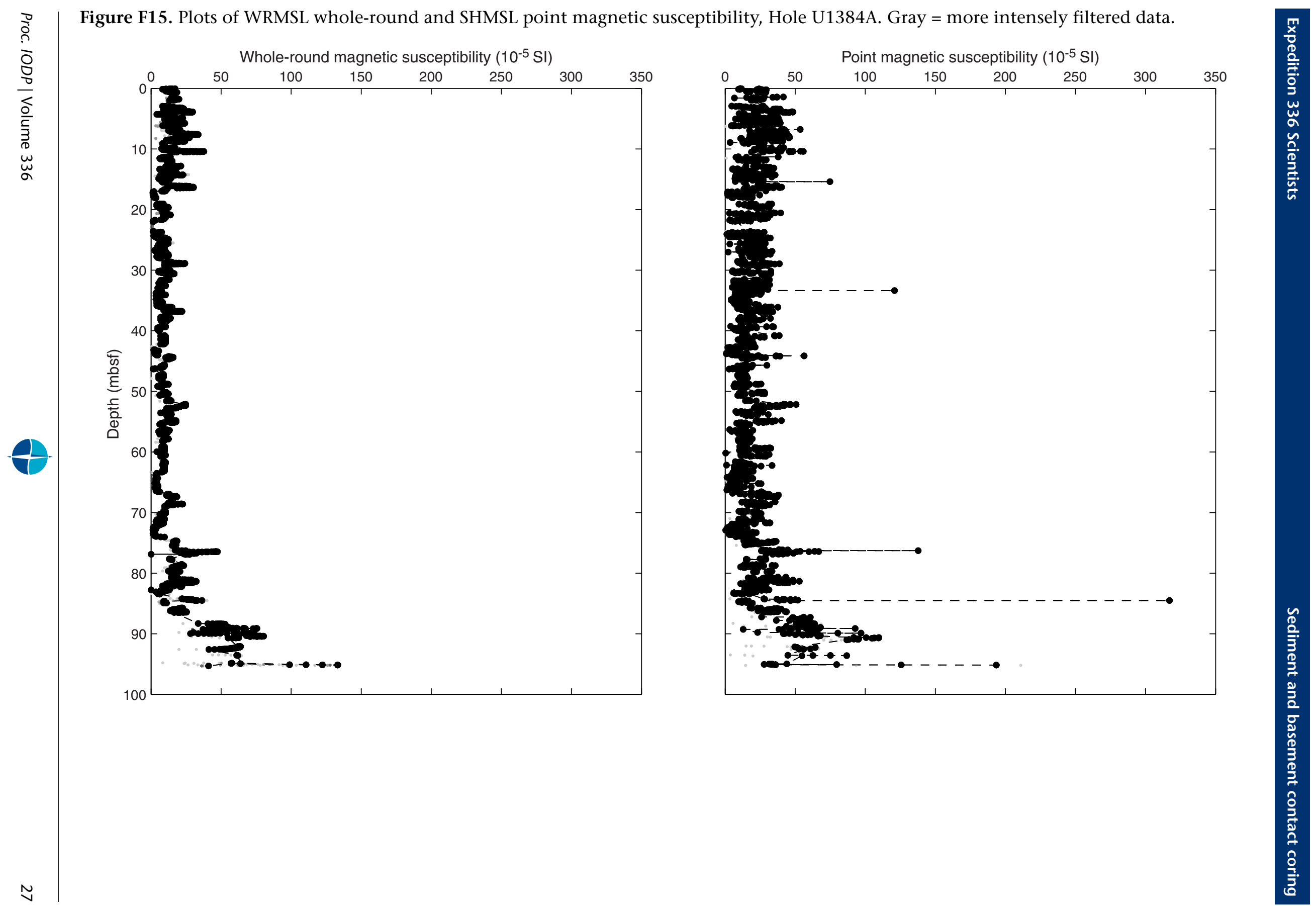

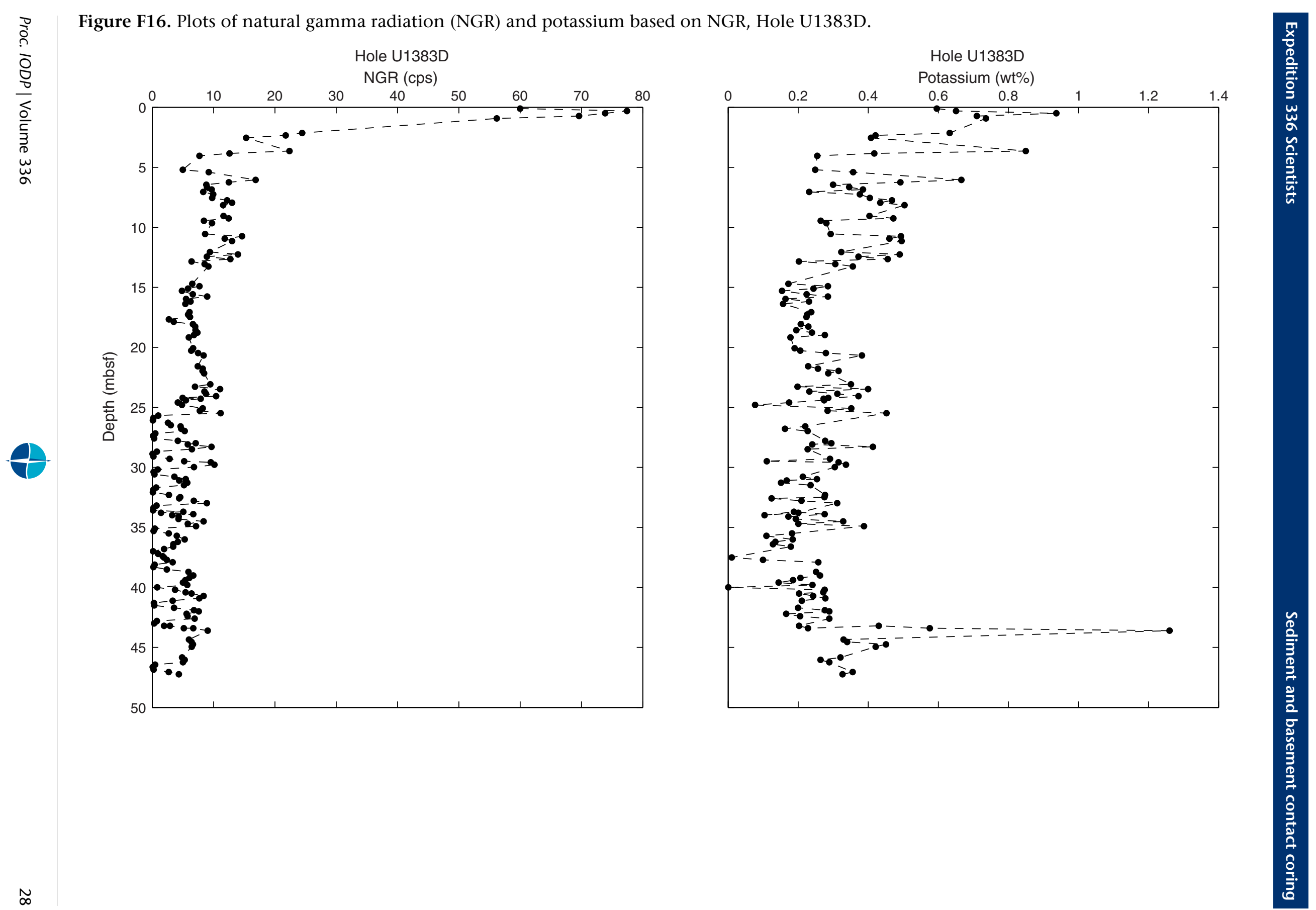
Figure F17. Plots of natural gamma radiation (NGR) spectra for peak located at $43.6 \mathrm{mbsf}$ and adjacent points, Section 336-U1383D-6H-1. Background has been subtracted.
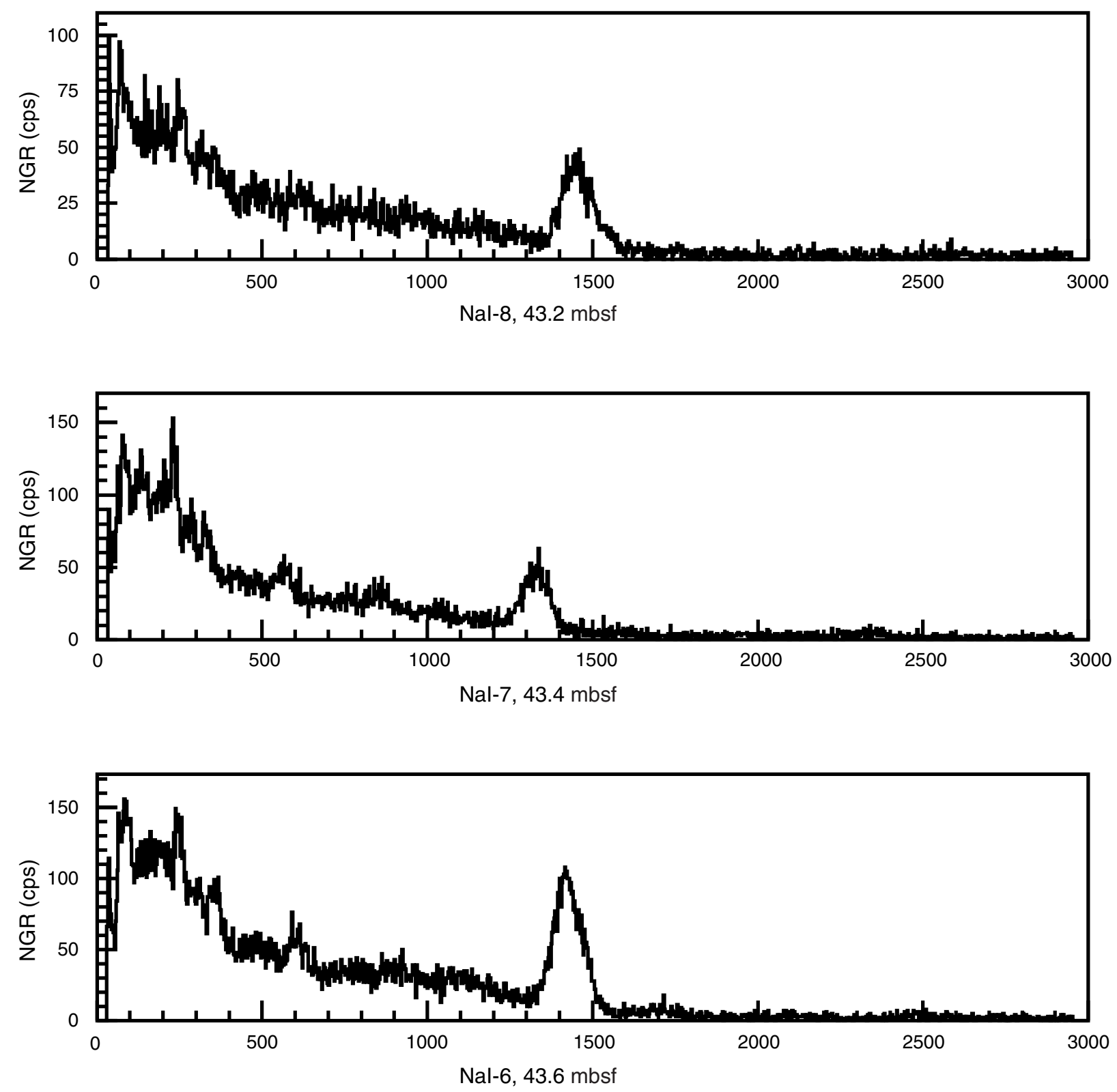


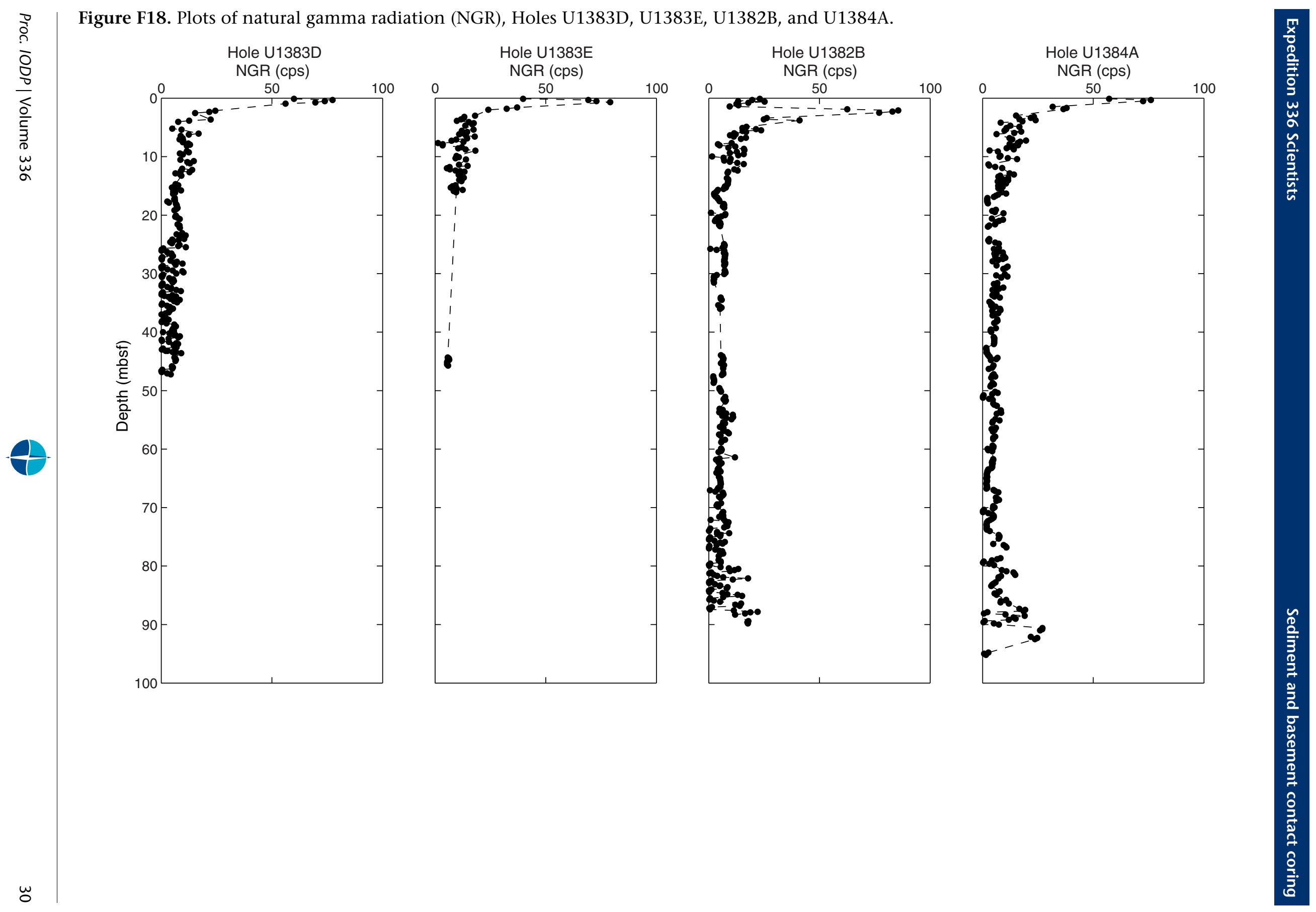




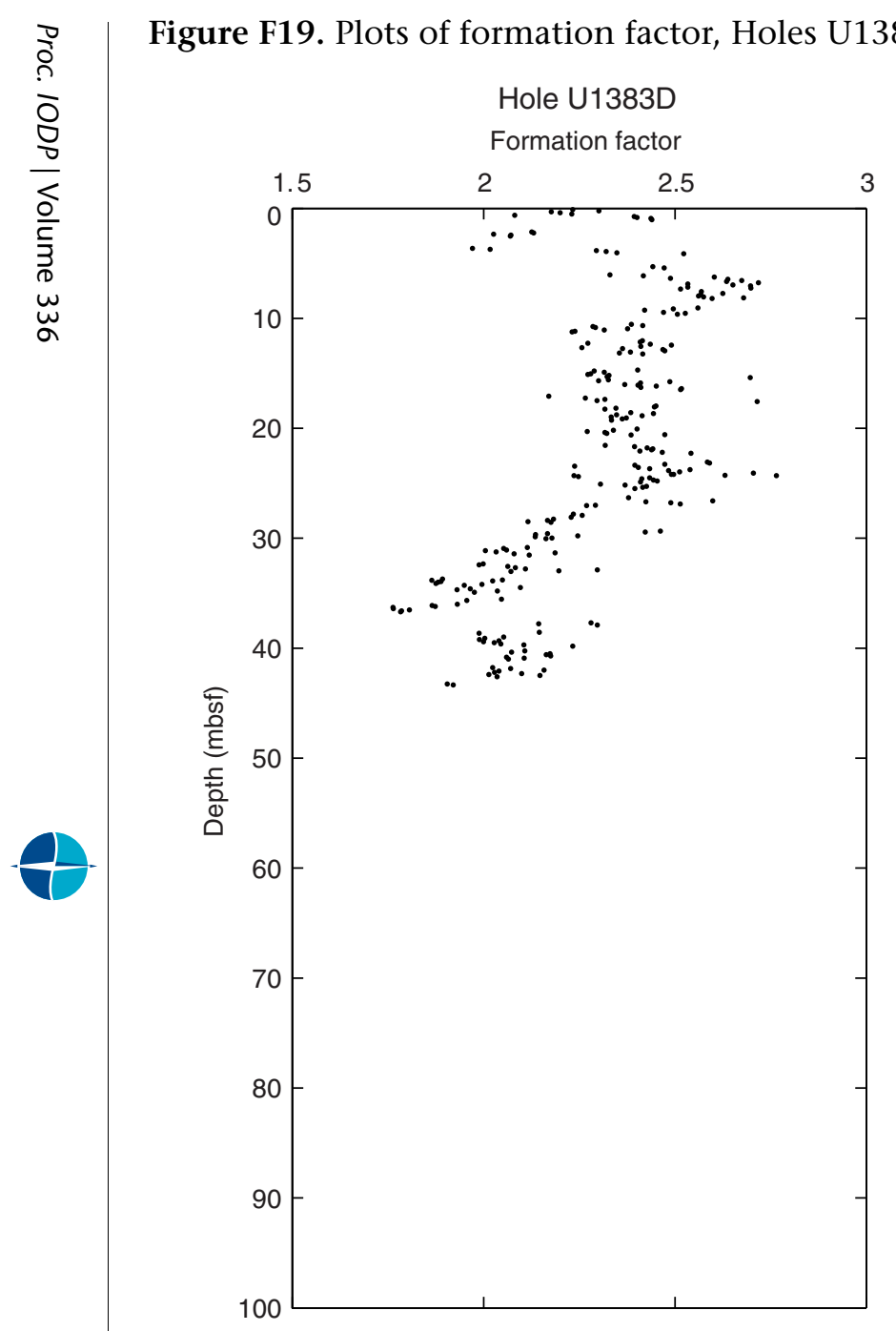

\section{U1382B, and U1384A.}

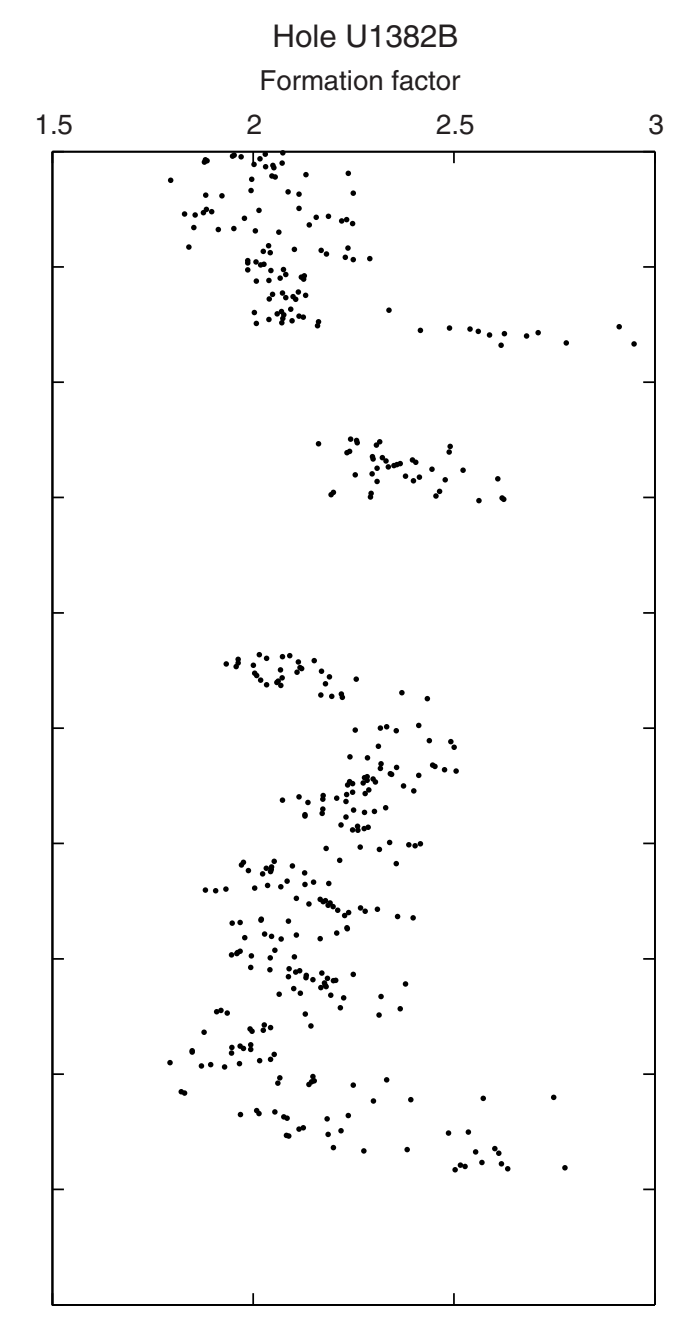

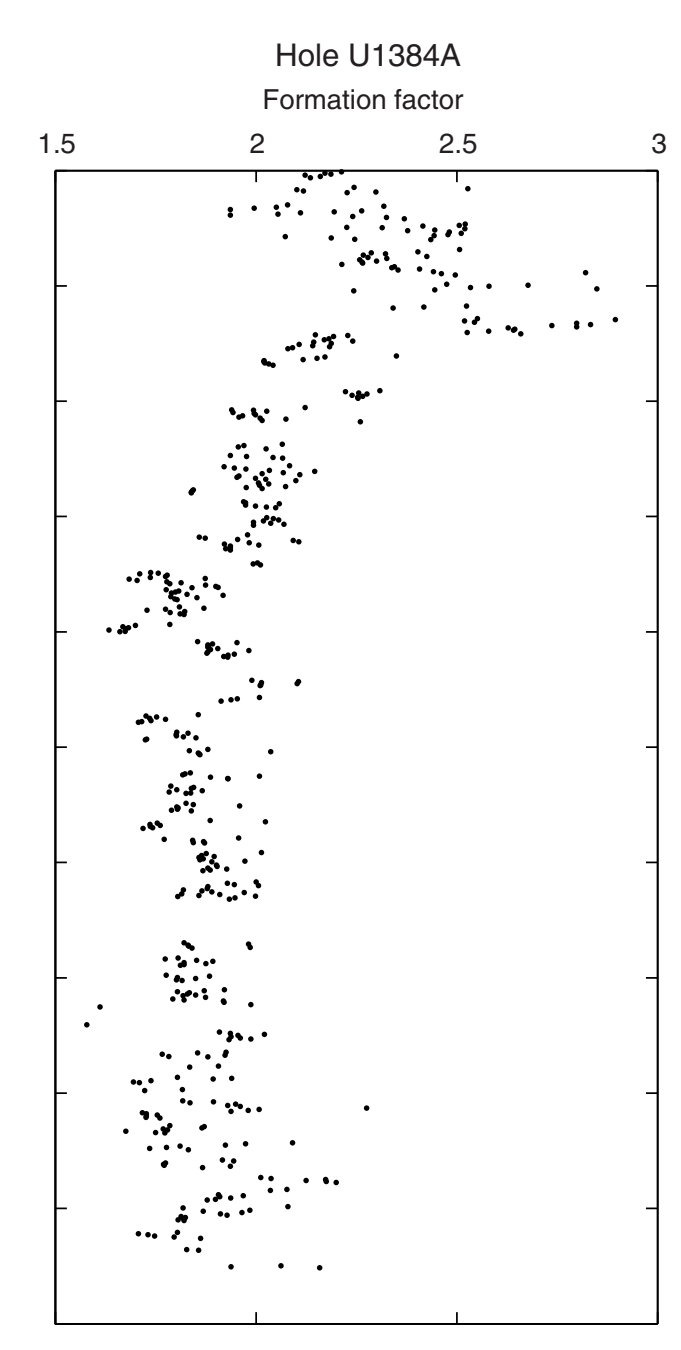

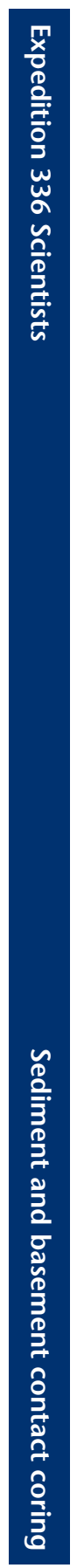


Figure F20. Plot of compressional $P$-wave velocity measurements for $x$ - (red), $y$ - (green), and $z$ - (blue) axes with the caliper and bayonets, respectively, and filtered (black) and unfiltered (gray) values for $P$-wave velocities measured with the WRMSL, Hole U1383D.

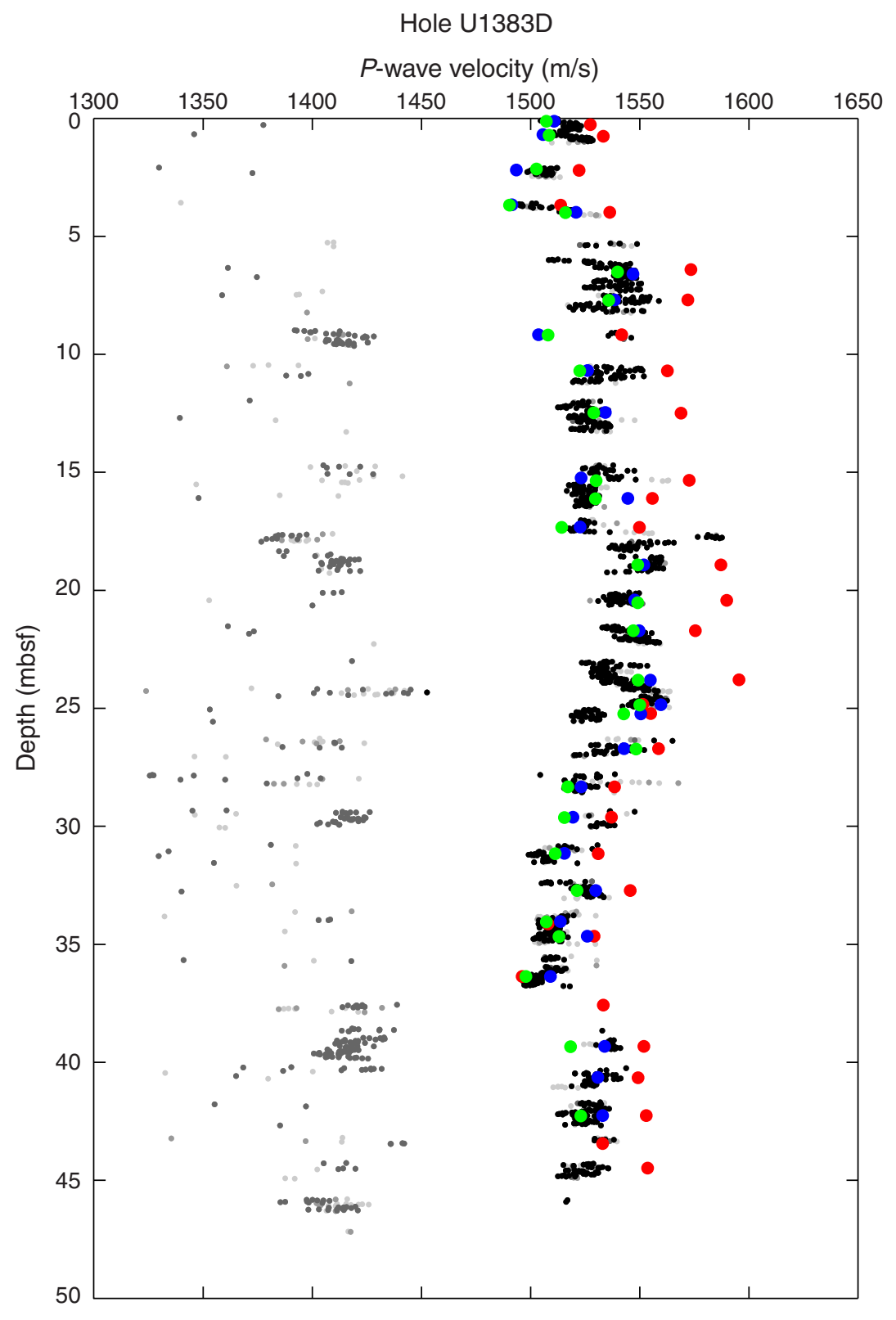


Figure F21. Plot of compressional $P$-wave velocity measurements obtained using the caliper (red) and filtered (black) and unfiltered (gray) values for $P$-wave velocities measured with the WRMSL, Hole U1383E.

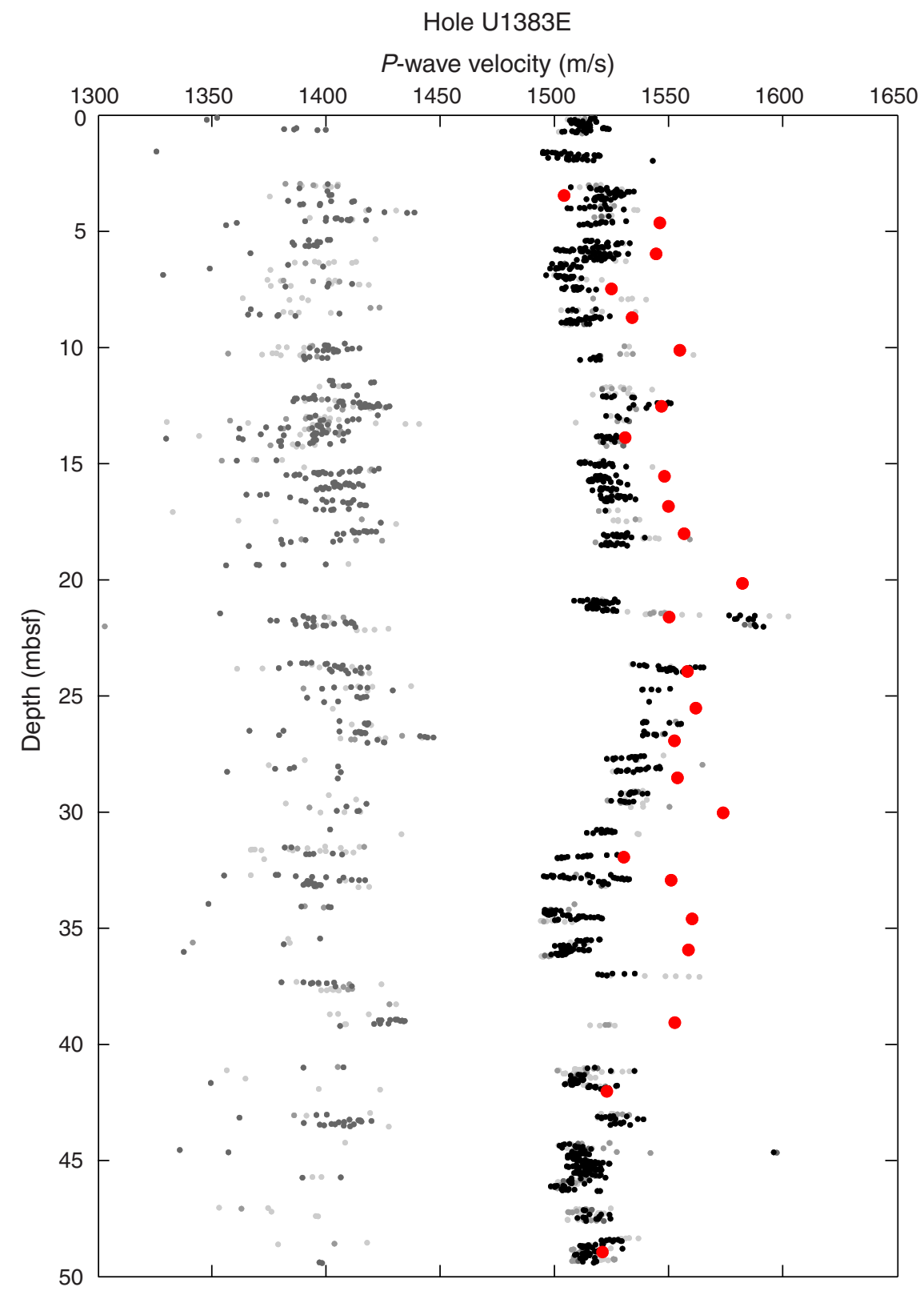


Figure F22. Plot of compressional $P$-wave velocity measurements obtained using the caliper (red) and filtered (black) and unfiltered (gray) values for $P$-wave velocities measured with the WRMSL, Hole U1382B.

Hole U1382B

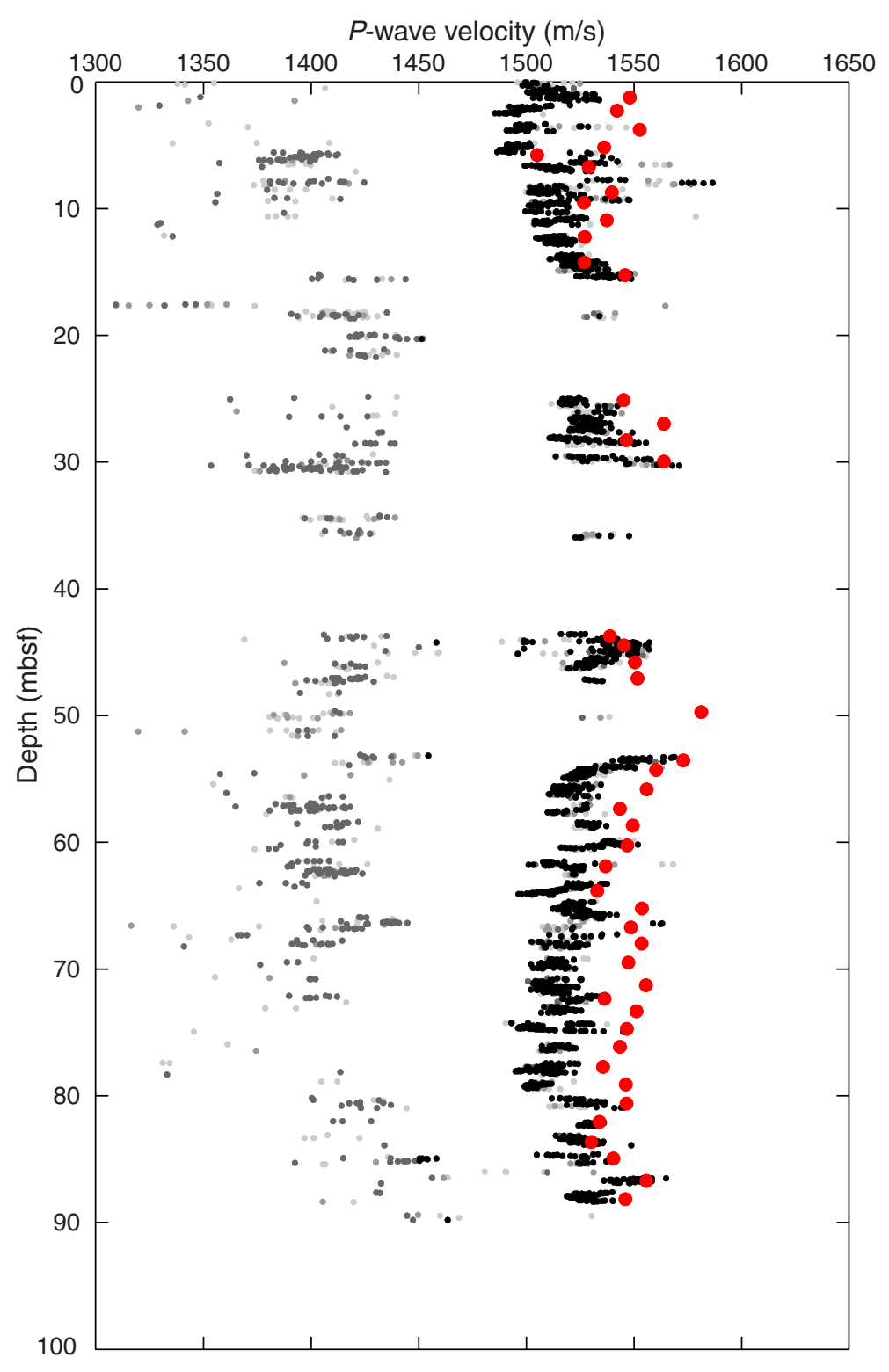


Figure F23. Plot of compressional $P$-wave velocity measurements obtained using the caliper (red) and filtered (black) and unfiltered (gray) values for $P$-wave velocities measured with the WRMSL, Hole U1384A.

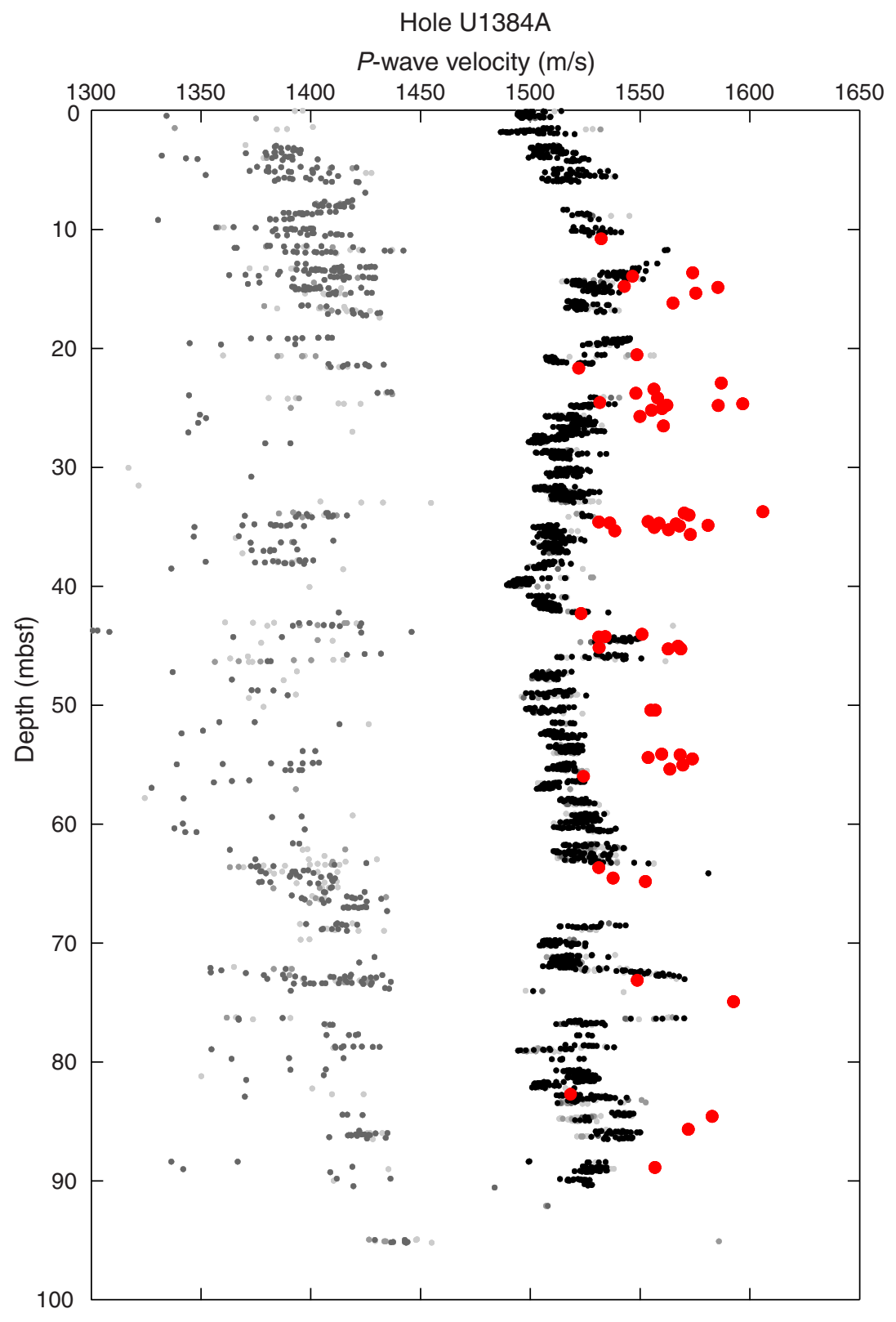


Figure F24. Plots of color reflectance and tristimulus axes values, Hole U1383D.
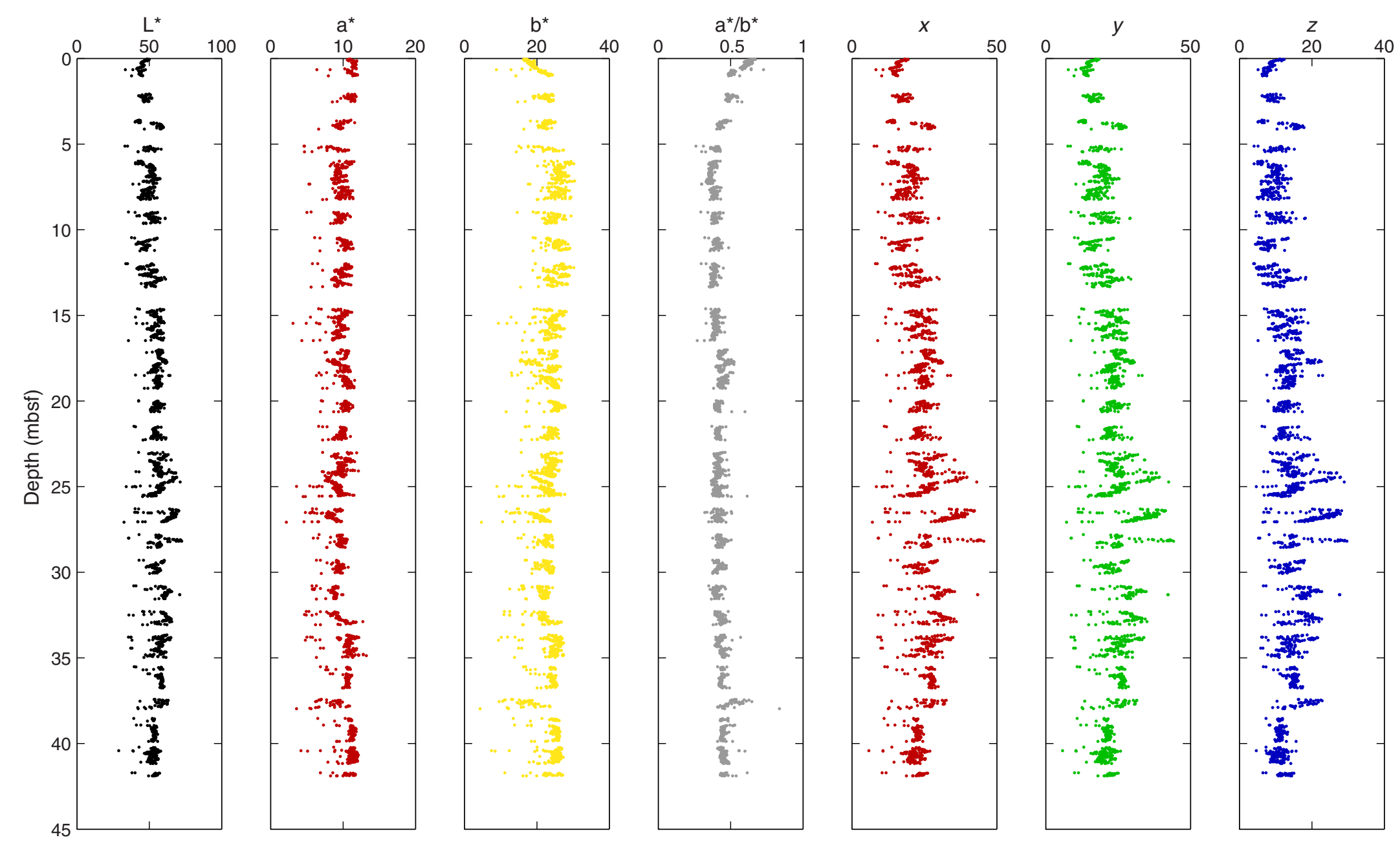


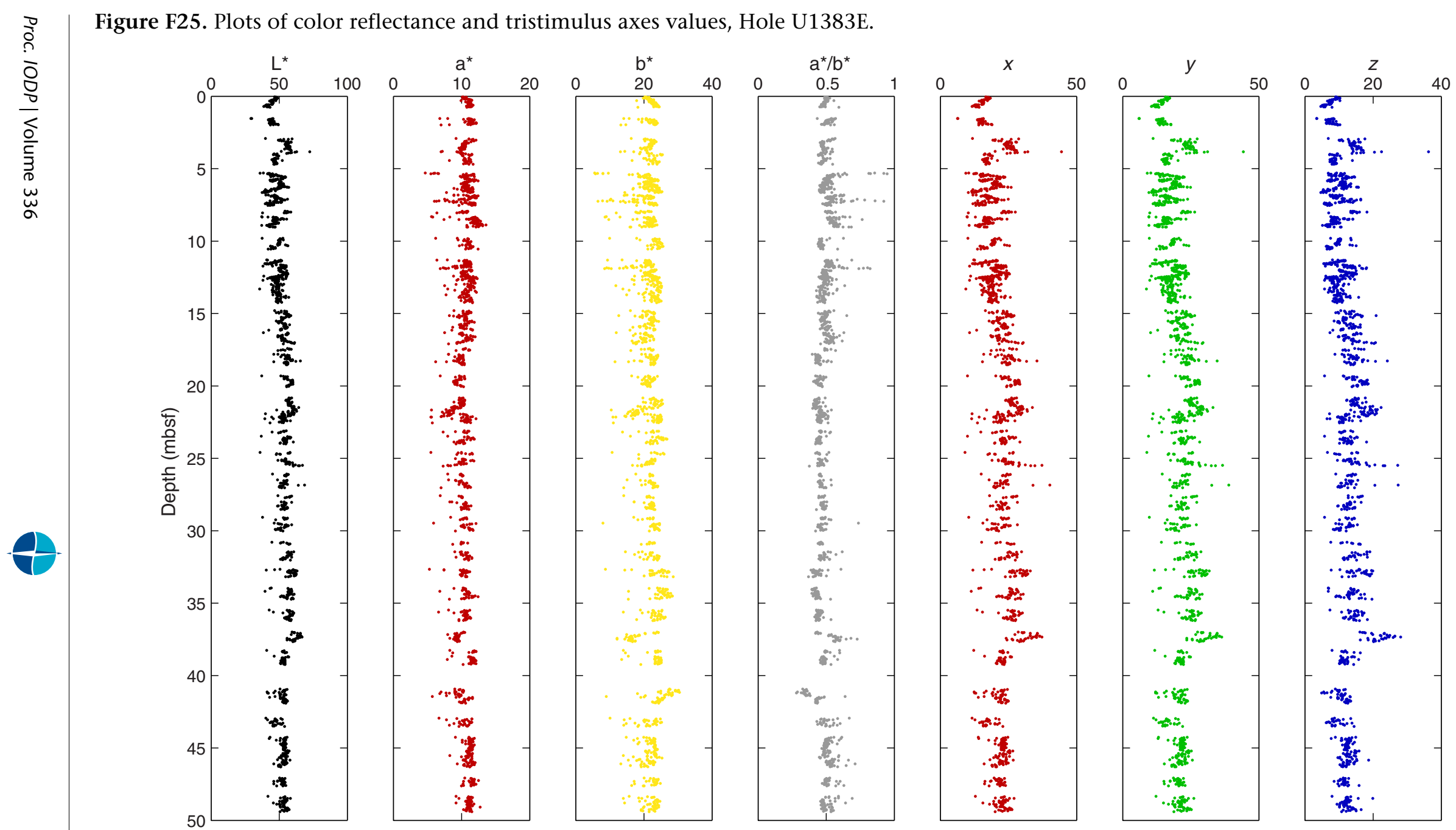




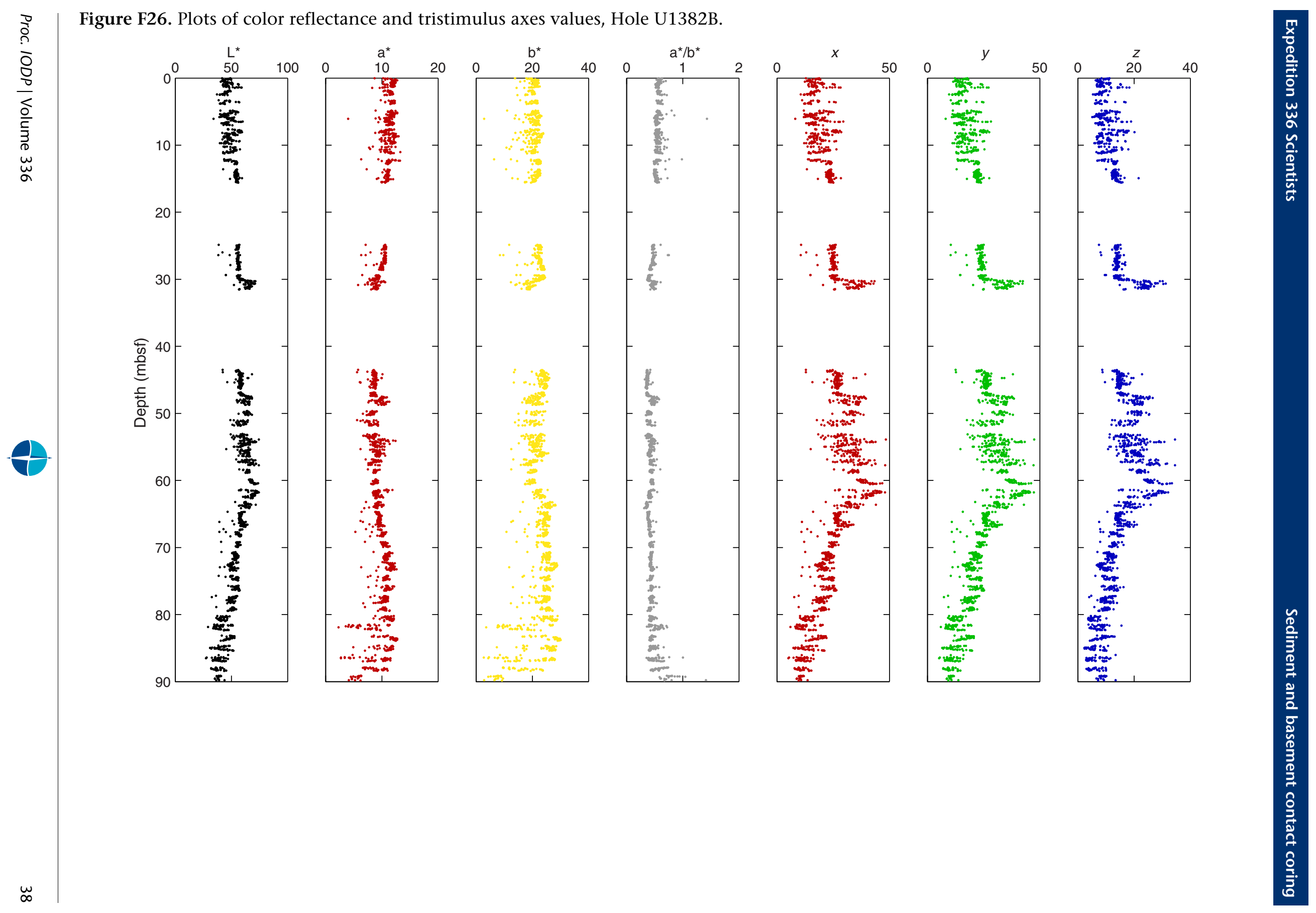


Figure F27. Plots of color reflectance and tristimulus axes values, Hole U1384A.
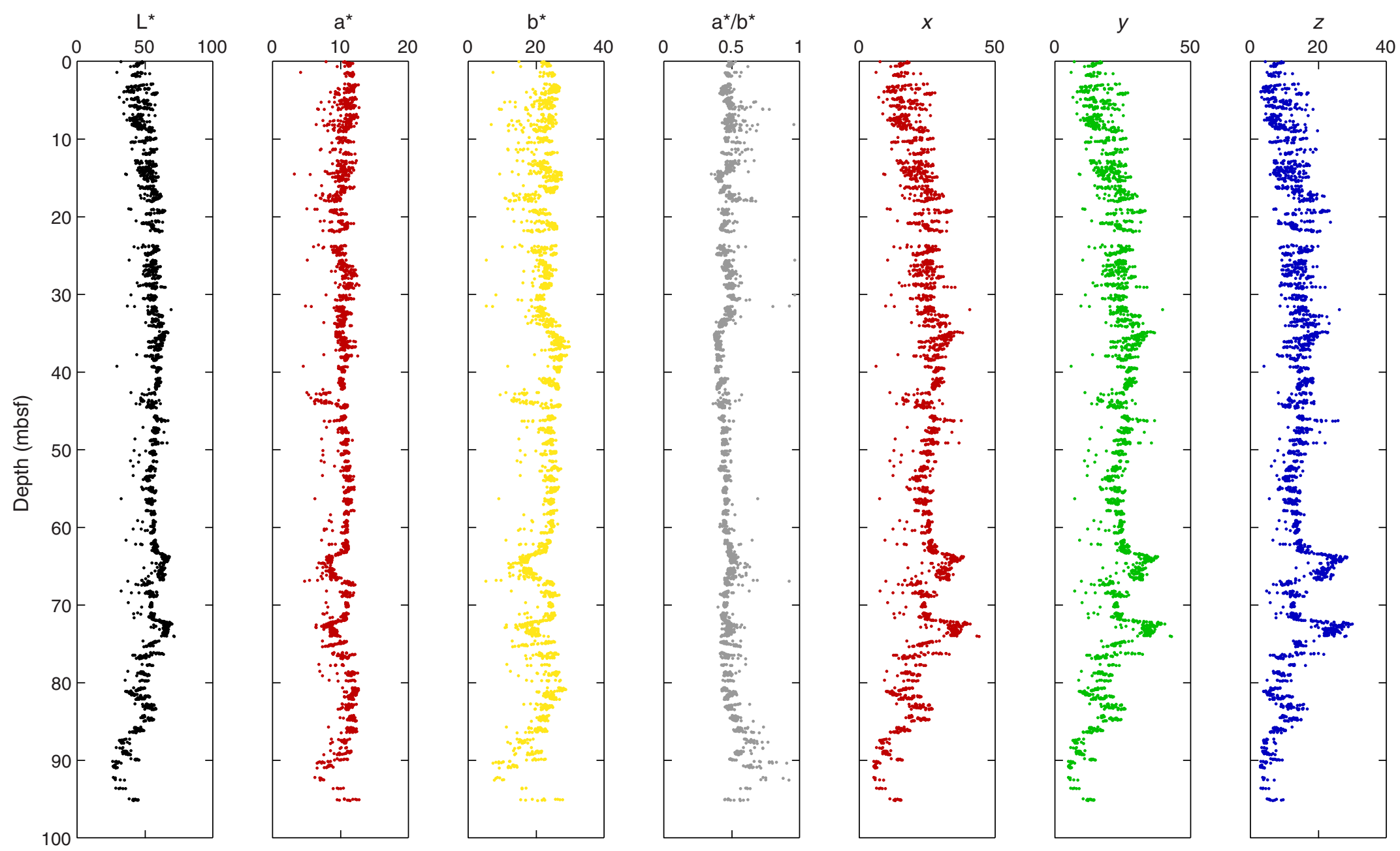
Figure F28. Plot of temperature-time records collected with the APCT-3, Cores 336-U1382B-3H through 5H.

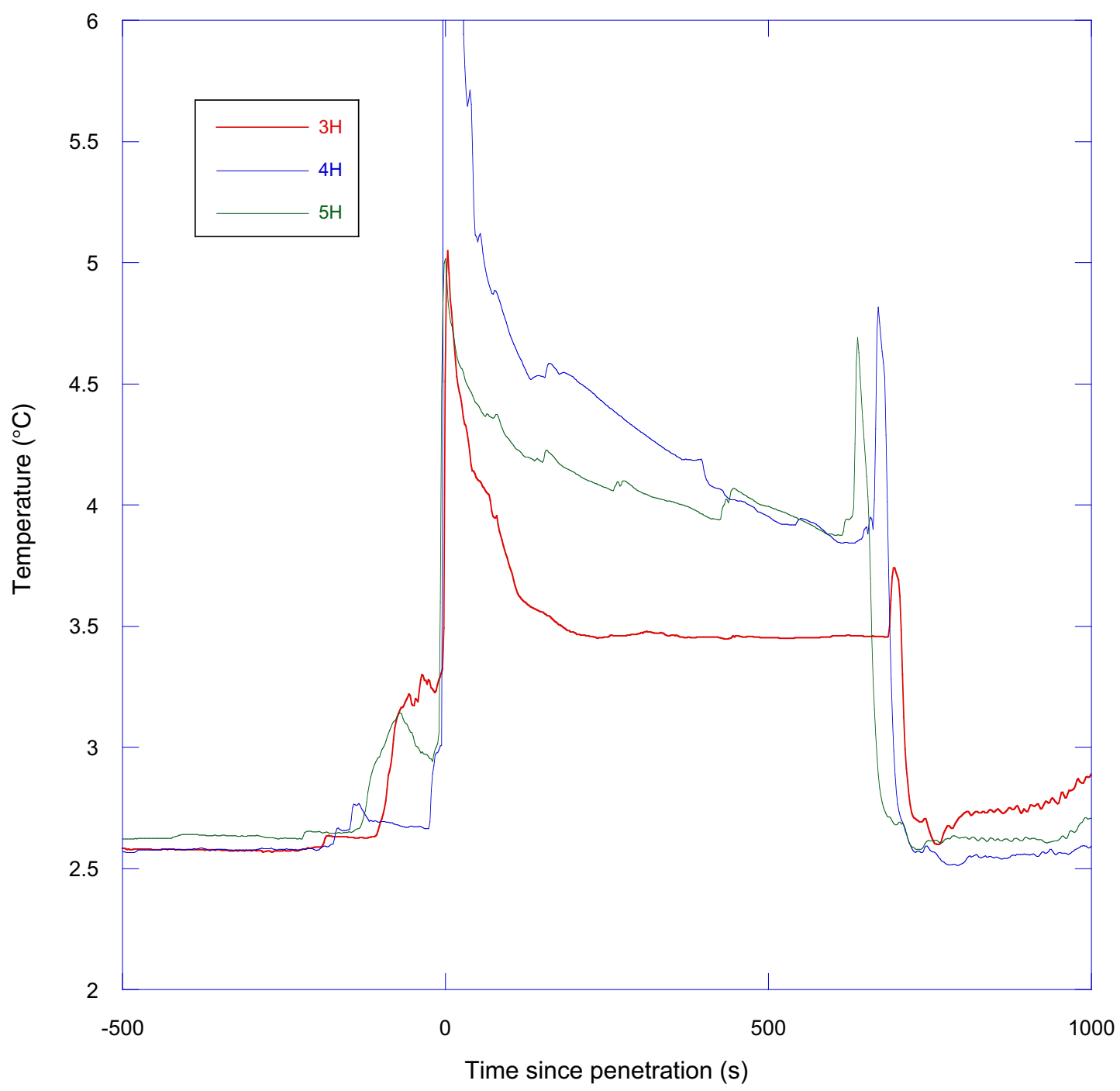


Table T1. Summary of operations completed, Holes U1383D, U1383E, U1382B, and U1384A.

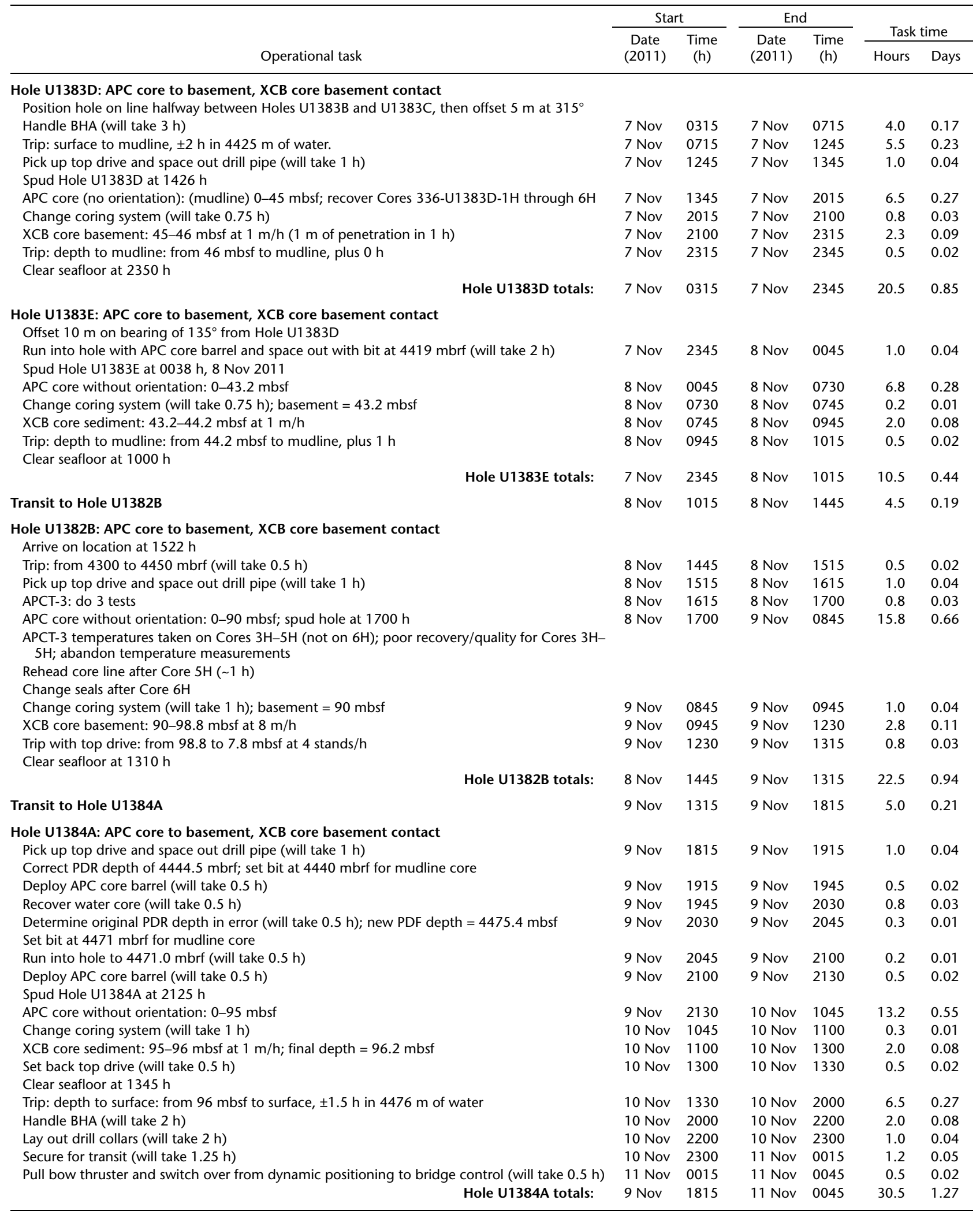

Operations included advanced piston coring (APC) of sediment overlying basement and extended core barrel (XCB) coring of the sediment/ basement contact. Times are local ship time, which is Universal Time Coordinated (UTC) $-3 \mathrm{~h}$. BHA = bottom-hole assembly. APCT-3 =advanced piston corer temperature tool. PDR = precision depth recorder. 
Table T2. Coring summary, Holes U1383D, U1383E, U1382B, and U1384A. (Continued on next page.)

Hole U1383D

Latitude: $22^{\circ} 48.1316^{\prime} \mathrm{N}$

Longitude: $46^{\circ} 03.1628^{\prime} \mathrm{W}$

Time on hole (h): 20.5 (0315 h, 7 November to 2345 h, 7 October 2011)

Seafloor (drill pipe measurement below rig floor in meters; DRF): 4425.2

Distance between rig floor and sea level $(\mathrm{m})$ : 11.4

Water depth (drill pipe measurement from sea level in meters): 4413.8

Total penetration (drilling depth below seafloor in meters; DSF): 44.3

Total depth (drill pipe measurement from rig floor in meters; DRF): 4469.5

Total length of cored section $(\mathrm{m}): 44.3$

Total core recovered $(\mathrm{m}): 48.7$

Core recovery (\%): 110

Total number of cores: 7

Hole U1383E

Latitude: $22^{\circ} 48.1283^{\prime} \mathrm{N}$

Longitude: $46^{\circ} 03.1582^{\prime} \mathrm{W}$

Time on site (h): 10.25 (2345 h, 7 November to 1000 h, 8 November 2011)

Seafloor (drill pipe measurement below rig floor in meters; DRF): 4425.2

Distance between rig floor and sea level $(\mathrm{m}): 11.5$

Water depth (drill pipe measurement from sea level in meters): 4413.7

Total penetration (drilling depth below seafloor in meters; DSF): 44.2

Total depth (drill pipe measurement from rig floor in meters; DRF): 4469.4

Total length of cored section $(\mathrm{m}): 44.2$

Total core recovered $(\mathrm{m}): 50.28$

Core recovery (\%): 114

Total number of cores: 7

Hole U1382B

Latitude: $22^{\circ} 45.3528^{\prime} \mathrm{N}$

Longitude: $46^{\circ} 04.8748^{\prime} \mathrm{E}$

Time on site (h): 22.5 (1515 h, 8 November to 1315 h, 9 November 2011)

Seafloor (drill pipe measurement below rig floor in meters; DRF): 4494.0

Distance between rig floor and sea level $(\mathrm{m}): 11.5$

Water depth (drill pipe measurement from sea level in meters): 4482.5

Total penetration (drilling depth below seafloor in meters; DSF): 98.8

Total depth (drill pipe measurement from rig floor in meters; DRF): 4592.8

Total length of cored section $(\mathrm{m}): 98.8$

Total core recovered $(\mathrm{m}): 84.3$

Core recovery (\%): 85

Total number of cores: 12

Hole U1384A

Latitude: $22^{\circ} 48.7086^{\prime} \mathrm{N}$

Longitude: $46^{\circ} 05.3464^{\prime} \mathrm{E}$

Time on site (h): 30.5 (1815 h, 9 November to 0045 h, 11 November 2011)

Seafloor (drill pipe measurement below rig floor in meters; DRF): 4475.9

Distance between rig floor and sea level $(\mathrm{m}): 11.5$

Water depth (drill pipe measurement from sea level in meters): 4464.4

Total penetration (drilling depth below seafloor in meters; DSF): 96.2

Total depth (drill pipe measurement from rig floor in meters; DRF): 472.1

Total length of cored section $(\mathrm{m}): 96.2$

Total core recovered $(\mathrm{m}): 94.1$

Core recovery (\%): 98

Total number of cores: 12

\begin{tabular}{|c|c|c|c|c|c|c|c|c|}
\hline \multirow[b]{2}{*}{ Core } & \multirow[b]{2}{*}{$\begin{array}{c}\text { Date } \\
\text { (2011) }\end{array}$} & \multirow[b]{2}{*}{$\begin{array}{c}\text { Time } \\
\text { (h) }\end{array}$} & \multicolumn{2}{|c|}{ Depth DSF (m) } & \multirow[b]{2}{*}{$\begin{array}{l}\text { Interval } \\
\text { cored } \\
(\mathrm{m})\end{array}$} & \multirow{2}{*}{$\begin{array}{l}\text { Length of } \\
\text { core } \\
\text { recovered } \\
(\mathrm{m})\end{array}$} & \multirow[b]{2}{*}{$\begin{array}{l}\text { Curated } \\
\text { length } \\
\text { (m) }\end{array}$} & \multirow[b]{2}{*}{$\begin{array}{l}\text { Recovery } \\
\text { (\%) }\end{array}$} \\
\hline & & & $\begin{array}{l}\text { Top of } \\
\text { cored } \\
\text { interval }\end{array}$ & $\begin{array}{l}\text { Bottom of } \\
\text { cored } \\
\text { interval }\end{array}$ & & & & \\
\hline \multicolumn{9}{|c|}{ 336-U1383D- } \\
\hline $1 \mathrm{H}$ & $7 \mathrm{Nov}$ & 1750 & 0 & 5.1 & 5.1 & 5.13 & 5.13 & 101 \\
\hline $2 \mathrm{H}$ & $7 \mathrm{Nov}$ & 1855 & 5.1 & 14.6 & 9.5 & 8.52 & 8.52 & 90 \\
\hline $3 \mathrm{H}$ & $7 \mathrm{Nov}$ & 1955 & 14.6 & 24.1 & 9.5 & 10.03 & 10.03 & 106 \\
\hline $4 \mathrm{H}$ & $7 \mathrm{Nov}$ & 2055 & 24.1 & 33.6 & 9.5 & 10.07 & 10.07 & 106 \\
\hline $5 \mathrm{H}$ & $7 \mathrm{Nov}$ & 2205 & 33.6 & 43.1 & 9.5 & 10.00 & 10.00 & 105 \\
\hline $6 \mathrm{H}$ & $7 \mathrm{Nov}$ & 2315 & 43.1 & 43.3 & 0.2 & 4.14 & 4.14 & 2070 \\
\hline $7 \mathrm{X}$ & $8 \mathrm{Nov}$ & 0220 & 43.3 & 44.3 & 1.0 & 0.76 & 0.83 & 76 \\
\hline
\end{tabular}


Table T2 (continued).

\begin{tabular}{|c|c|c|c|c|c|c|c|c|}
\hline \multirow[b]{2}{*}{ Core } & \multirow[b]{2}{*}{$\begin{array}{c}\text { Date } \\
(2011)\end{array}$} & \multirow[b]{2}{*}{$\begin{array}{c}\text { Time } \\
\text { (h) }\end{array}$} & \multicolumn{2}{|c|}{ Depth DSF (m) } & \multirow[b]{2}{*}{$\begin{array}{l}\text { Interval } \\
\text { cored } \\
(\mathrm{m})\end{array}$} & \multirow{2}{*}{$\begin{array}{l}\text { Length of } \\
\text { core } \\
\text { recovered } \\
(\mathrm{m})\end{array}$} & \multirow[b]{2}{*}{$\begin{array}{l}\text { Curated } \\
\text { length } \\
\text { (m) }\end{array}$} & \multirow[b]{2}{*}{$\begin{array}{c}\text { Recovery } \\
(\%)\end{array}$} \\
\hline & & & $\begin{array}{l}\text { Top of } \\
\text { cored } \\
\text { interval }\end{array}$ & $\begin{array}{l}\text { Bottom of } \\
\text { cored } \\
\text { interval }\end{array}$ & & & & \\
\hline \multicolumn{9}{|c|}{ 336-U1383E- } \\
\hline $1 \mathrm{H}$ & $8 \mathrm{Nov}$ & 0405 & 0.0 & 2.9 & 2.9 & 3.11 & 3.11 & 107 \\
\hline $2 \mathrm{H}$ & $8 \mathrm{Nov}$ & 0515 & 2.9 & 12.4 & 9.5 & 10.14 & 10.14 & 107 \\
\hline $3 \mathrm{H}$ & $8 \mathrm{Nov}$ & 0635 & 12.4 & 21.9 & 9.5 & 10.06 & 10.06 & 106 \\
\hline $4 \mathrm{H}$ & $8 \mathrm{Nov}$ & 0750 & 21.9 & 31.4 & 9.5 & 9.23 & 9.23 & 97 \\
\hline $5 \mathrm{H}$ & $8 \mathrm{Nov}$ & 0915 & 31.4 & 40.9 & 9.5 & 8.92 & 8.92 & 94 \\
\hline $6 \mathrm{H}$ & $8 \mathrm{Nov}$ & 1025 & 40.9 & 43.2 & 2.3 & 8.52 & 8.52 & 370 \\
\hline \multirow[t]{2}{*}{$7 X$} & $8 \mathrm{Nov}$ & 1215 & 43.2 & 44.2 & 1.0 & 0.30 & 0.31 & 30 \\
\hline & & & & Totals: & 44.2 & 50.3 & & 114 \\
\hline \multicolumn{9}{|c|}{ 336-U1382B- } \\
\hline $1 \mathrm{H}$ & $8 \mathrm{Nov}$ & 2025 & 0.0 & 5.5 & 5.5 & 6.45 & 7.80 & 117 \\
\hline $2 \mathrm{H}$ & $8 \mathrm{Nov}$ & 2110 & 5.5 & 15.0 & 9.5 & 9.62 & 9.62 & 101 \\
\hline $3 \mathrm{H}$ & $8 \mathrm{Nov}$ & 2335 & 15.0 & 24.5 & 9.5 & 7.66 & 7.66 & 81 \\
\hline $4 \mathrm{H}$ & $9 \mathrm{Nov}$ & 0110 & 24.5 & 34.0 & 9.5 & 8.05 & 8.05 & 85 \\
\hline $5 \mathrm{H}$ & $9 \mathrm{Nov}$ & 0250 & 34.0 & 43.5 & 9.5 & 3.00 & 3.00 & 32 \\
\hline $6 \mathrm{H}$ & $9 \mathrm{Nov}$ & 0540 & 43.5 & 53.0 & 9.5 & 9.18 & 9.18 & 97 \\
\hline $7 \mathrm{H}$ & $9 \mathrm{Nov}$ & 0740 & 53.0 & 62.5 & 9.5 & 9.96 & 9.96 & 105 \\
\hline $8 \mathrm{H}$ & $9 \mathrm{Nov}$ & 0915 & 62.5 & 72.0 & 9.5 & 9.96 & 9.96 & 105 \\
\hline $9 \mathrm{H}$ & $9 \mathrm{Nov}$ & 1030 & 72.0 & 81.5 & 9.5 & 10.26 & 10.26 & 108 \\
\hline $10 \mathrm{H}$ & $9 \mathrm{Nov}$ & 1150 & 81.5 & 90.0 & 8.5 & 9.56 & 9.56 & 112 \\
\hline $11 x$ & $9 \mathrm{Nov}$ & 1320 & 90.0 & 94.7 & 4.7 & 0.40 & 0.40 & 9 \\
\hline \multirow[t]{2}{*}{$12 X$} & $9 \mathrm{Nov}$ & 1515 & 94.7 & 98.8 & 4.1 & 0.18 & 0.26 & 4 \\
\hline & & & & Totals: & 98.8 & 84.3 & & 85 \\
\hline \multicolumn{9}{|c|}{ 336-U1384A- } \\
\hline $1 \mathrm{H}$ & $10 \mathrm{Nov}$ & 0105 & 0.0 & 4.6 & 4.6 & 4.64 & 4.64 & 101 \\
\hline $2 \mathrm{H}$ & $10 \mathrm{Nov}$ & 0220 & 4.6 & 14.1 & 9.5 & 10.00 & 10.00 & 105 \\
\hline $3 \mathrm{H}$ & $10 \mathrm{Nov}$ & 0330 & 14.1 & 23.6 & 9.5 & 8.06 & 8.06 & 85 \\
\hline $4 \mathrm{H}$ & $10 \mathrm{Nov}$ & 0450 & 23.6 & 33.1 & 9.5 & 9.55 & 9.55 & 101 \\
\hline $5 \mathrm{H}$ & $10 \mathrm{Nov}$ & 0610 & 33.1 & 42.6 & 9.5 & 9.33 & 9.33 & 98 \\
\hline $6 \mathrm{H}$ & $10 \mathrm{Nov}$ & 0730 & 42.6 & 52.1 & 9.5 & 9.23 & 9.23 & 97 \\
\hline $7 \mathrm{H}$ & $10 \mathrm{Nov}$ & 0850 & 52.1 & 61.6 & 9.5 & 8.87 & 8.87 & 93 \\
\hline $8 \mathrm{H}$ & $10 \mathrm{Nov}$ & 1005 & 61.6 & 71.1 & 9.5 & 9.75 & 9.75 & 103 \\
\hline $9 \mathrm{H}$ & $10 \mathrm{Nov}$ & 1120 & 71.1 & 80.6 & 9.5 & 9.11 & 9.11 & 96 \\
\hline $10 \mathrm{H}$ & $10 \mathrm{Nov}$ & 1230 & 80.6 & 90.1 & 9.5 & 9.81 & 9.81 & 103 \\
\hline $11 \mathrm{H}$ & $10 \mathrm{Nov}$ & 1340 & 90.1 & 94.7 & 4.6 & 5.16 & 5.16 & 112 \\
\hline \multirow[t]{2}{*}{$12 X$} & $10 \mathrm{Nov}$ & 1555 & 94.7 & 96.2 & 1.5 & 0.58 & 0.63 & 39 \\
\hline & & & & Totals: & 96.2 & 94.1 & & 98 \\
\hline
\end{tabular}

Ship local time is Universal Time Coordinated (UTC) $-3 \mathrm{~h}$. DRF $=$ drilling depth below rig floor, DSF $=$ drilling depth below seafloor. $\mathrm{H}=$ advanced piston corer, $\mathrm{X}=$ extended core barrel. 
Table T3. Chemical analyses on pore fluids extracted using Rhizon samplers.

\begin{tabular}{|c|c|c|c|c|c|}
\hline \multirow[b]{2}{*}{$\begin{array}{l}\text { Core, section, } \\
\text { interval }(\mathrm{cm})\end{array}$} & \multicolumn{2}{|c|}{ Depth } & \multirow[b]{2}{*}{$\begin{array}{l}\mathrm{PO}_{4} \\
(\mu \mathrm{M})\end{array}$} & \multirow[b]{2}{*}{$\begin{array}{c}\mathrm{NO}_{3}+\mathrm{NO}_{2} \\
(\mu \mathrm{M})\end{array}$} & \multirow[b]{2}{*}{$\begin{array}{l}\mathrm{NH}_{4} \\
(\mu \mathrm{M}\end{array}$} \\
\hline & $\begin{array}{l}\text { Top section } \\
\text { (mbsf) }\end{array}$ & $\begin{array}{c}\text { Sample } \\
\text { (mbsf) }\end{array}$ & & & \\
\hline Bottom water* & & 0 & 1.47 & 21.05 & \\
\hline \multicolumn{6}{|l|}{ 336-U1383D- } \\
\hline $1 \mathrm{H}-1,20$ & 0 & 0.2 & 1.51 & 25.5 & $<6$ \\
\hline $1 \mathrm{H}-3,20$ & 2.04 & 2.24 & 1.84 & 33.3 & 8.5 \\
\hline $1 \mathrm{H}-4,35$ & 3.54 & 3.89 & 1.84 & 34.1 & 7.9 \\
\hline $2 \mathrm{H}-1,20$ & 5.1 & 5.3 & 1.57 & 24.7 & 9.8 \\
\hline $2 \mathrm{H}-3,30$ & 7.45 & 7.75 & 1.48 & 29.9 & $<6$ \\
\hline $2 \mathrm{H}-5,25$ & 10.45 & 10.7 & 0.96 & 21.3 & $<6$ \\
\hline $3 \mathrm{H}-1,70$ & 14.6 & 15.3 & 1.32 & 31.9 & $<6$ \\
\hline $3 \mathrm{H}-5,60$ & 19.97 & 20.57 & 1.13 & 29.0 & $<6$ \\
\hline $4 \mathrm{H}-2,30$ & 24.98 & 25.28 & 1.18 & 31.2 & 9.8 \\
\hline $4 \mathrm{H}-3,30$ & 26.48 & 26.78 & 1.02 & 27.6 & 12 \\
\hline $4 \mathrm{H}-5,30$ & 29.48 & 29.78 & 1.32 & 33.6 & 8.5 \\
\hline $5 \mathrm{H}-1,30$ & 33.6 & 33.9 & 1.24 & 37.5 & $<6$ \\
\hline $5 \mathrm{H}-2,30$ & 34.4 & 34.7 & 1.07 & 27.5 & $<6$ \\
\hline $5 \mathrm{H}-3,30$ & 35.9 & 36.2 & 0.85 & 25.6 & 9.5 \\
\hline $5 \mathrm{H}-4,20$ & 37.4 & 37.6 & 0.79 & 24.8 & 7.1 \\
\hline $5 \mathrm{H}-5,40$ & 38.9 & 39.3 & 0.90 & 28.3 & 20 \\
\hline $5 \mathrm{H}-6,30$ & 40.4 & 40.7 & 0.96 & 29.1 & 11 \\
\hline $5 \mathrm{H}-7,40$ & 41.9 & 42.3 & 1.02 & - & 8.8 \\
\hline \multicolumn{6}{|l|}{ 336-U1383E- } \\
\hline $1 \mathrm{H}-1,30$ & 0 & 0.3 & 1.70 & 28.3 & $<6$ \\
\hline $1 \mathrm{H}-2,25$ & 1.5 & 1.75 & 2.02 & 32.2 & 10 \\
\hline $2 \mathrm{H}-1,40$ & 3.1 & 3.5 & 1.90 & 30.5 & 11 \\
\hline $2 \mathrm{H}-4,40$ & 6.98 & 7.38 & 1.86 & 34.9 & 7.7 \\
\hline $2 \mathrm{H}-6,40$ & 9.98 & 10.38 & 1.81 & 35.1 & $<6$ \\
\hline $3 \mathrm{H}-4,40$ & 16.28 & 16.68 & 1.72 & 38.7 & 9.9 \\
\hline $3 \mathrm{H}-6,40$ & 19.28 & 19.68 & 1.72 & 37.5 & $<6$ \\
\hline $4 \mathrm{H}-3,30$ & 23.46 & 23.76 & 1.54 & 36.5 & 11 \\
\hline $4 \mathrm{H}-5,30$ & 26.46 & 26.76 & 1.40 & 37.5 & 12 \\
\hline $4 \mathrm{H}-7,30$ & 29.46 & 29.76 & 1.46 & - & $<6$ \\
\hline $5 \mathrm{H}-2,30$ & 32.65 & 32.95 & 1.51 & 38.8 & 15 \\
\hline $5 \mathrm{H}-4,30$ & 35.65 & 35.95 & 1.31 & 34.8 & 16 \\
\hline $5 \mathrm{H}-6,30$ & 38.65 & 38.95 & 1.16 & 35.4 & 15 \\
\hline $6 \mathrm{H}-1,30$ & 40.9 & 41.2 & 1.05 & 31.4 & 16 \\
\hline $6 \mathrm{H}-2,25$ & 41.43 & 41.68 & 1.07 & 35.0 & 13 \\
\hline $6 \mathrm{H}-3,30$ & 42.93 & 43.23 & 1.03 & 33.3 & $<6$ \\
\hline $6 \mathrm{H}-4,30$ & 44.23 & 44.53 & 1.13 & 28.2 & 26 \\
\hline $6 \mathrm{H}-5,30$ & 45.73 & 46.03 & 1.00 & 28.3 & 21 \\
\hline $6 \mathrm{H}-6,30$ & 47.03 & 47.33 & 0.92 & 26.9 & 21 \\
\hline $6 \mathrm{H}-7,30$ & 48.53 & 48.83 & 1.04 & 28.2 & 25 \\
\hline \multicolumn{6}{|l|}{ 336-U1382B- } \\
\hline $1 \mathrm{H}-1,38$ & 0 & 0.38 & 1.60 & 26.8 & 2.5 \\
\hline $1 \mathrm{H}-3,30$ & 1.8 & 2.1 & 1.79 & 35.3 & $<1.5$ \\
\hline $1 \mathrm{H}-5,30$ & 4.8 & 5.1 & 1.87 & 34.1 & $<1.5$ \\
\hline $2 \mathrm{H}-4,30$ & 9.07 & 9.37 & 1.56 & 35.3 & 2.2 \\
\hline $2 \mathrm{H}-6,40$ & 12.07 & 12.47 & 1.71 & 36.2 & $<1.5$ \\
\hline $3 \mathrm{H}-3,67$ & 18 & 18.67 & 1.35 & 36.9 & 4.0 \\
\hline
\end{tabular}

\begin{tabular}{|c|c|c|c|c|c|}
\hline \multirow[b]{2}{*}{$\begin{array}{l}\text { Core, section, } \\
\text { interval }(\mathrm{cm})\end{array}$} & \multicolumn{2}{|c|}{ Depth } & \multirow[b]{2}{*}{$\begin{array}{l}\mathrm{PO}_{4} \\
(\mu \mathrm{M})\end{array}$} & \multirow[b]{2}{*}{$\begin{array}{c}\mathrm{NO}_{3}+\mathrm{NO}_{2} \\
(\mu \mathrm{M})\end{array}$} & \multirow[b]{2}{*}{$\begin{array}{l}\mathrm{NH}_{4} \\
(\mu \mathrm{M}\end{array}$} \\
\hline & $\begin{array}{l}\text { Top section } \\
\text { (mbsf) }\end{array}$ & $\begin{array}{c}\text { Sample } \\
\text { (mbsf) }\end{array}$ & & & \\
\hline $3 \mathrm{H}-4,4$ & 19.5 & 19.54 & 1.46 & 36.2 & 1.8 \\
\hline $4 \mathrm{H}-4,70$ & 27.85 & 28.55 & 1.46 & 35.1 & \\
\hline $4 \mathrm{H}-5,80$ & 29.35 & 30.15 & 1.43 & 34.8 & $<1.5$ \\
\hline $5 \mathrm{H}-2,55$ & 35.31 & 35.86 & 1.42 & 35.6 & $<1.5$ \\
\hline $6 \mathrm{H}-4,15$ & 46.84 & 46.99 & 1.38 & 35.2 & $<1.5$ \\
\hline $6 \mathrm{H}-8,15$ & 50.98 & 51.13 & 1.40 & 33.5 & $<1.5$ \\
\hline 7H- 4,40 & 56.81 & 57.21 & 1.37 & 34.1 & $<1.5$ \\
\hline $7 \mathrm{H}-6,70$ & 59.81 & 60.51 & 1.33 & 32.0 & $<1.5$ \\
\hline $8 \mathrm{H}-(3) 2,110$ & 64.65 & 65.75 & 1.21 & 35.6 & $<1.5$ \\
\hline $8 \mathrm{H}-5,60$ & 67.65 & 68.25 & 1.09 & 33.1 & $<1.5$ \\
\hline $9 \mathrm{H}-2,40$ & 72.88 & 73.28 & 0.97 & 31.4 & $<1.5$ \\
\hline $9 \mathrm{H}-5,90$ & 77.38 & 78.28 & 0.95 & 32.1 & $<1.5$ \\
\hline $10 \mathrm{H}-2,36$ & 81.81 & 82.17 & 0.98 & 31.2 & $<1.5$ \\
\hline $10 \mathrm{H}-3,30$ & 83.31 & 83.61 & 0.97 & 31.1 & $<1.5$ \\
\hline $10 \mathrm{H}-4,45$ & 84.81 & 85.26 & 0.89 & 30.2 & $<1.5$ \\
\hline $10 \mathrm{H}-5,30$ & 86.31 & 86.61 & 0.95 & 30.0 & $<1.5$ \\
\hline $10 \mathrm{H}-6,30$ & 87.81 & 88.11 & 1.02 & 30.4 & - \\
\hline $10 \mathrm{H}-7,30$ & 89.31 & 89.61 & 0.81 & 30.4 & - \\
\hline \multicolumn{6}{|l|}{ 336-U1384A- } \\
\hline $1 \mathrm{H}-2,50$ & 1.37 & 1.87 & 1.66 & 31.3 & $<1.5$ \\
\hline $1 \mathrm{H}-3,100$ & 2.87 & 3.87 & 1.60 & 34.1 & $<1.5$ \\
\hline $2 \mathrm{H}-3,12$ & 6.74 & 6.86 & 1.42 & 32.7 & $<1.5$ \\
\hline $2 \mathrm{H}-4,80$ & 8.24 & 9.04 & 1.57 & 36.9 & $<1.5$ \\
\hline $2 \mathrm{H}-7,20$ & 12.74 & 12.94 & 1.40 & 34.1 & $<1.5$ \\
\hline $3 \mathrm{H}-3,25$ & 15.98 & 16.23 & 1.23 & 34.3 & $<1.5$ \\
\hline $3 \mathrm{H}-6,75$ & 20.48 & 21.23 & 1.35 & 41.3 & $<1.5$ \\
\hline $4 \mathrm{H}-2,90$ & 23.99 & 24.89 & 1.17 & 37.9 & $<1.5$ \\
\hline $4 \mathrm{H}-6,90$ & 29.99 & 30.89 & 1.35 & 44.5 & $<1.5$ \\
\hline $5 \mathrm{H}-2,55$ & 33.6 & 34.15 & 1.29 & 42.2 & $<1.5$ \\
\hline $5 \mathrm{H}-7,16$ & 40.74 & 40.9 & 1.18 & 44.8 & $<1.5$ \\
\hline $6 \mathrm{H}-2,40$ & 44.1 & 44.5 & 1.11 & 46.3 & $<1.5$ \\
\hline $6 \mathrm{H}-5,30$ & 48.6 & 48.9 & 1.02 & 43.6 & $<1.5$ \\
\hline $6 \mathrm{H}-6,60$ & 50.1 & 50.7 & 1.00 & 45.7 & $<1.5$ \\
\hline $7 \mathrm{H}-2,70$ & 53.28 & 53.98 & 1.08 & 45.4 & $<1.5$ \\
\hline 7H- 4,60 & 56.28 & 56.88 & 1.04 & 49.1 & $<1.5$ \\
\hline $7 \mathrm{H}-6,60$ & 59.28 & 59.88 & 0.97 & 45.8 & 1.6 \\
\hline $8 \mathrm{H}-2,35$ & 62.17 & 62.52 & 0.81 & 41.2 & $<1.5$ \\
\hline $9 \mathrm{H}-4,65$ & 74.61 & 75.26 & 0.79 & 36.8 & $<1.5$ \\
\hline $9 \mathrm{H}-7,19$ & 78.53 & 78.72 & 0.83 & 36.3 & $<1.5$ \\
\hline $10 \mathrm{H}-5,20$ & 85.7 & 85.9 & 0.77 & 35.5 & 1.6 \\
\hline $10 \mathrm{H}-6,40$ & 87.2 & 87.6 & 0.77 & 31.4 & $<1.5$ \\
\hline $10 \mathrm{H}-7,35$ & 88.7 & 89.05 & 0.81 & 30.5 & $<1.5$ \\
\hline $11 \mathrm{H}-1,10$ & 90.1 & 90.2 & 0.78 & 28.2 & $<1.5$ \\
\hline $11 \mathrm{H}-2,30$ & 90.5 & 90.8 & 0.80 & 27.1 & $<1.5$ \\
\hline $11 \mathrm{H}-3,35$ & 92 & 92.35 & 0.95 & 26.0 & $<1.5$ \\
\hline $11 \mathrm{H}-5,35$ & 94.9 & 95.25 & 1.07 & 23.5 & $<1.5$ \\
\hline
\end{tabular}

* = Ziebis et al. (2012). - = not analyzed. 
Table T4. Pore water data, Holes U1382A, U1382B, U1383D, U1383E, and U1384A. This table is available in an oversized format.

Table T5. Results of microsphere contamination checks in sediment whole-round cores collected during IODP Expedition 336.

\begin{tabular}{|c|c|c|c|c|}
\hline \multirow[b]{2}{*}{ Label identifier } & \multirow{2}{*}{$\begin{array}{l}\text { Depth } \\
\text { (mbsf) }\end{array}$} & \multirow[b]{2}{*}{ ID } & \multicolumn{2}{|c|}{ Microspheres } \\
\hline & & & Interior & Exterior \\
\hline 336-U1382B-1H-1-ORCU & 0 & 73,74 & - & - \\
\hline 336-U1382B-1H-3-ORCU & 1.8 & 71,72 & - & - \\
\hline 336-U1382B-1H-4-ORCU & 3.3 & 69,70 & + & + \\
\hline 336-U1382B-2H-2-ORCU TPICK & 6.07 & 79,80 & + & + \\
\hline 336-U1382B-2H-4-ORCU TPICK & 9.07 & 77,78 & + & + \\
\hline 336-U1382B-2H-6-ORCU TPICK & 12.07 & 75,76 & + & - \\
\hline 336-U1382B-3H-2-ORCU & 16.5 & 83,84 & - & - \\
\hline 336-U1382B-3H-4-ORCU & 19.7 & 81,82 & - & - \\
\hline 336-U1382B-4H-2-ORCU TPICK & 24.85 & 87,88 & + & + \\
\hline 336-U1382B-4H-5-ORCU TPICK & 29.35 & 85,86 & - & - \\
\hline 336-U1382B-5H-2-ORCU TPICK & 35.96 & 89,90 & - & + \\
\hline 336-U1382B-6H-3-ORCU TPICK & 45.34 & 93,94 & - & + \\
\hline 336-U1382B-6H-7-ORCU TPICK & 49.48 & 91,92 & - & - \\
\hline 336-U1382B-7H-3-ORCU TPICK & 55.31 & 99,100 & + & + \\
\hline 336-U1382B-7H-4-ORCU TPICK & 56.81 & 97,98 & - & - \\
\hline 336-U1382B-7H-6-ORCU TPICK & 59.81 & 95,96 & - & - \\
\hline 336-U1382B-8H-2-ORCU & 63.15 & 105,106 & + & +++ \\
\hline 336-U1382B-8H-4-ORCU & 66.15 & 103,104 & + & ++++ \\
\hline 336-U1382B-8H-6-ORCU & 69.15 & 101,102 & - & + \\
\hline 336-U1382B-9H-2-ORCU TPICK & 72.88 & 111,112 & - & + \\
\hline 336-U1382B-9H-4-ORCU TPICK & 75.88 & 109,110 & - & +++ \\
\hline 336-U1382B-9H-6-ORCU TPICK & 78.88 & 107,108 & - & + \\
\hline 336-U1382B-10H-2-ORCU TPICK & 81.81 & 117,118 & + & + \\
\hline 336-U1382B-10H-4-ORCU & 84.81 & 115,116 & - & + \\
\hline 336-U1382B-10H-6-ORCU & 87.81 & 113,114 & - & + \\
\hline 336-U1383D-1H-1-ORCU TPICK & 0 & 5,6 & - & - \\
\hline 336-U1383D-1H-2-ORCU TPICK & 0.63 & 3,4 & - & - \\
\hline 336-U1383D-1H-3-ORCU TPICK & 2.04 & 1,2 & - & - \\
\hline 336-U1383D-2H-1-ORCU TPICK & 5.1 & 11,12 & +++ & ++++ \\
\hline 336-U1383D-2H-3-ORCU TPICK & 7.45 & 9,10 & + & ++++ \\
\hline 336-U1383D-2H-5-ORCU TPICK & 10.45 & 8 & NA & ++++ \\
\hline 336-U1383D-3H-2-ORCU TPICK & 15.47 & 17,18 & ++ & +++ \\
\hline 336-U1383D-3H-4-ORCU TPICK & 18.47 & 15,16 & ++ & ++++ \\
\hline 336-U1383D-3H-6-ORCU TPICK & 21.47 & 13,14 & + & + \\
\hline 336-U1383D-4H-2-ORCU TPICK & 24.98 & 23,24 & - & - \\
\hline 336-U1383D-4H-4-ORCU TPICK & 27.98 & 21,22 & + & + \\
\hline 336-U1383D-4H-6-ORCU TPICK & 30.98 & 19,20 & - & + \\
\hline 336-U1383D-5H-2-ORCU TPICK & 34.4 & 29,30 & - & + \\
\hline 336-U1383D-5H-4-ORCU TPICK & 37.4 & 27,28 & - & - \\
\hline 336-U1383D-5H-6-ORCU TPICK & 40.4 & 25,26 & - & + \\
\hline 336-U1383D-6H-2-ORCU TPICK & 44.24 & 33,34 & + & + \\
\hline 336-U1383D-6H-3-ORCU TPICK & 47.23 & 31,32 & + & + \\
\hline 336-U1383E-1H-1-ORCU TPICK & 0 & 37,38 & - & - \\
\hline 336-U1383E-1H-2-ORCU TPICK & 1.5 & 35,36 & - & - \\
\hline 336-U1383E-2H-2-ORCU TPICK & 3.78 & 43,44 & - & + \\
\hline 336-U1383E-2H-4-ORCU TPICK & 6.78 & 41,42 & - & - \\
\hline 336-U1383E-2H-6-ORCU TPICK & 9.78 & 39,40 & - & + \\
\hline 336-U1383E-3H-2-ORCU TPICK & 13.28 & 45,50 & + & + \\
\hline 336-U1383E-3H-4-ORCU TPICK & 16.28 & 48,49 & + & ++ \\
\hline
\end{tabular}

\begin{tabular}{rllcc}
\hline & \multicolumn{2}{c}{ Depth } & & \multicolumn{2}{c}{ Microspheres } \\
\cline { 4 - 6 } Label identifier & (mbsf) & ID & Interior & Exterior \\
\hline 336-U1383E-3H-6-ORCU TPICK & 19.28 & 46,47 & - & ++ \\
336-U1383E-4H-1-ORCU TPICK & 21.9 & 55,56 & - & + \\
336-U1383E-4H-4-ORCU TPICK & 24.96 & 53,54 & + & + \\
336-U1383E-4H-6-ORCU TPICK & 27.96 & 51,52 & - & + \\
336-U1383E-5H-1-ORCU TPICK & 31.4 & 61 & + & NA \\
336-U1383E-5H-3-ORCU TPICK & 34.15 & 59,60 & ++ & +++ \\
336-U1383E-5H-5-ORCU TPICK & 37.15 & 57,58 & + & +++ \\
336-U1383E-5H-6-ORCU TPICK & 38.65 & 67,68 & - & + \\
336-U1383E-6H-3-ORCU TPICK & 42.93 & 65,66 & - & ++ \\
336-U1383E-6H-5-ORCU TPICK & 45.73 & 63,64 & + & + \\
336-U1384A-1H-2-ORCU TPICK & 1.37 & 121,122 & - & + \\
336-U1384A-1H-3-ORCU TPICK & 2.87 & 119,120 & + & + \\
336-U1384A-2H-2-ORCU TPICK & 5.24 & NA & & \\
336-U1384A-2H-3-ORCU TPICK & 6.74 & 129,130 & - & ++ \\
336-U1384A-2H-4-ORCU TPICK & 8.24 & 125 & - & \\
336-U1384A-2H-6-ORCU TPICK & 11.24 & 123,124 & - & + \\
336-U1384A-3H-2-ORCU TPICK & 14.48 & 135,136 & + & - \\
336-U1384A-3H-3-ORCU TPICK & 15.98 & 133,134 & - & + \\
336-U1384A-3H-5-ORCU TPICK & 18.98 & 131,132 & + & ++ \\
336-U1384A-4H-2-ORCU TPICK & 23.99 & 141,142 & + & + \\
336-U1384A-4H-4-ORCU TPICK & 26.99 & 139,140 & - & + \\
336-U1384A-4H-6-ORCU TPICK & 29.99 & 137,138 & - & + \\
336-U1384A-5H-2-ORCU TPICK & 34.33 & 147,148 & - & + \\
336-U1384A-5H-4-ORCU TPICK & 36.24 & 145,146 & - & ++ \\
336-U1384A-5H-6-ORCU TPICK & 39.24 & 143,144 & + & - \\
336-U1384A-6H-3-ORCU TPICK & 45.6 & 151,152 & - & + \\
336-U1384A-6H-5-ORCU TPICK & 48.6 & 149,150 & - & - \\
336-U1384A-7H-1-ORCU TPICK & 52.1 & 157,158 & - & + \\
336-U1384A-7H-3-ORCU TPICK & 54.78 & 155,156 & + & ++ \\
336-U1384A-7H-5-ORCU TPICK & 57.78 & 153,154 & - & + \\
336-U1384A-8H-3-ORCU TPICK & 63.67 & 161,162 & + & - \\
336-U1384A-8H-6-ORCU TPICK & 68.17 & 159,160 & + & + \\
336-U1384A-9H-4-ORCU TPICK & 74.61 & 165,166 & - & + \\
336-U1384A-9H-6-ORCU TPICK & 77.61 & 163,164 & - & ++ \\
336-U1384A-10H-2-ORCU TPICK & 81.2 & 171,172 & + & + \\
336-U1384A-10H-4-ORCU TPICK & 84.2 & 169,170 & + & + \\
336-U1384A-10H-6-ORCU TPICK & 87.2 & 167,168 & - & +++ \\
336-U1384A-11H-2-ORCU TPICK & 90.5 & 175,176 & + & ++ \\
336-U1384A-11H-4-ORCU TPICK & 93.5 & 173,174 & - & + \\
\hline & & & & \\
\hline
\end{tabular}

Microsphere abundance indicated qualitatively: $-=$ no microspheres detected, $+=<1$ microsphere per field of view (FOV), $++=1-5$ microspheres/FOV, $+++=5-10$ microspheres/FOV, $++++=10-100$ microspheres/FOV, NA = no sample available due to damage or loss. Samples were collected by toothpick from interior and exterior of cores and stored in $\sim 1 \mathrm{~mL}$ filtered $1 \times$ PBS or seawater. ID = internal identification number assigned onboard to each sample collected. 
Table T6. Moisture and density values (minimum, maximum, mean, and standard deviation [SD]), Holes U1383D, U1383E, U1382B, and U1384A.

\begin{tabular}{llllllll}
\hline \multirow{2}{*}{ Hole } & Value & \multicolumn{3}{c}{ Density $\left(\mathrm{g} / \mathrm{cm}^{3}\right)$} & $\begin{array}{c}\text { Porosity } \\
(\%)\end{array}$ & $\begin{array}{l}\text { Void } \\
\text { ratio }\end{array}$ \\
\cline { 3 - 7 } GRA bulk & Bulk & Dry & Grain & & \\
\hline \multirow{2}{*}{ U1383D } & Minimum & 1.03 & 1.51 & 0.78 & 2.6 & 59.49 & 1.47 \\
& Maximum & 1.78 & 1.69 & 1.07 & 2.82 & 70.95 & 2.44 \\
& Mean & 1.62 & 1.63 & 0.97 & 2.71 & 64.18 & 1.81 \\
& SD & 0.12 & 0.05 & 0.08 & 0.05 & 2.79 & 0.23 \\
U1383E & Minimum & 1.04 & 1.58 & 0.79 & 2.62 & 59.94 & 1.5 \\
& Maximum & 1.91 & 1.68 & 1.06 & 2.81 & 70.56 & 2.39 \\
& Mean & 1.58 & 1.61 & 0.94 & 2.71 & 65.27 & 1.9 \\
& SD & 0.11 & 0.05 & 0.08 & 0.05 & 3.01 & 0.25 \\
& Minimum & 1.07 & 1.53 & 0.81 & 2.59 & 58.38 & 1.4 \\
& Maximum & 2.37 & 1.71 & 1.1 & 2.78 & 70.29 & 2.37 \\
& Mean & 1.61 & 1.63 & 0.98 & 2.7 & 63.72 & 1.77 \\
& SD & 0.15 & 0.05 & 0.08 & 0.04 & 2.94 & 0.23 \\
& Minimum & 1.03 & 1.39 & 0.69 & 2.17 & 59.45 & 1.47 \\
& Maximum & 2.68 & 1.71 & 1.1 & 2.83 & 70.78 & 2.42 \\
& Mean & 1.6 & 1.63 & 0.98 & 2.71 & 63.77 & 1.78 \\
& SD & 0.14 & 0.06 & 0.08 & 0.08 & 2.85 & 0.24 \\
\hline
\end{tabular}

GRA = gamma ray attenuation.

Table T7. Summary of color reflectance values (minimum, maximum, mean, and standard deviation [SD]), Holes U1383D, U1383E, U1382B, and U1384A.

\begin{tabular}{llcccccc}
\hline \multirow{2}{*}{ Hole } & Value & $\mathrm{a}^{*}$ & $\mathrm{~b}^{*}$ & $\mathrm{~L}^{*}$ & $\begin{array}{c}x \text { - } \\
\text { tristimulus }\end{array}$ & $\begin{array}{c}y \text { - } \\
\text { tristimulus }\end{array}$ & $\begin{array}{c}z- \\
\text { tristimulus }\end{array}$ \\
\hline \multirow{2}{*}{ U1383D } & Minimum & 2.2 & 4.3 & 28.8 & 5.8 & 5.8 & 3.9 \\
& Maximum & 13.2 & 30.4 & 72.4 & 45.5 & 44.2 & 29.7 \\
& Mean & 9.81 & 23.24 & 52.3 & 23.7 & 22.75 & 13.1 \\
& SD & 1.28 & 3.18 & 6.06 & 5.75 & 5.75 & 4.45 \\
U1383EE & Minimum & 3.1 & 5.5 & 28.2 & 5.5 & 5.5 & 3.1 \\
& Maximum & 13.6 & 30.5 & 72.4 & 44.3 & 44.3 & 36.3 \\
& Mean & 10.5 & 21.57 & 51.59 & 20.18 & 20.18 & 11.86 \\
& SD & 1.18 & 3.21 & 5.55 & 4.85 & 4.82 & 3.65 \\
U1382B B & Minimum & 2.3 & 2.7 & 27.3 & 5.1 & 5.2 & 2.3 \\
& Maximum & 13.3 & 30 & 74.5 & 48.4 & 47.5 & 34.6 \\
& Mean & 9.87 & 21.74 & 54.11 & 23.98 & 23.03 & 13.89 \\
& SD & 1.6 & 4.02 & 8.5 & 7.93 & 7.95 & 5.83 \\
& Minimum & 3.2 & 5.1 & 26.2 & 5.2 & 4.8 & 2.9 \\
& Maximum & 12.7 & 29.7 & 71.5 & 44 & 42.9 & 30 \\
& Mean & 10.26 & 22.11 & 53.48 & 23.24 & 22.21 & 13.15 \\
& SD & 1.22 & 3.68 & 7.45 & 6.43 & 6.43 & 4.89 \\
\hline
\end{tabular}

